\title{
Metageografías del Miedo: El Albayzín, sin trazado único
}

\author{
Ana Castro Moreno
}

\section{Directora}

Carmen Gregorio Gil

Profesora titular de Antropología Social

Universidad de Granada

\section{Directora de Apoyo}

Elissa Helms

Gender, Nation, State: Anthropological Perspective

Central European University

Granada Septiembre 2012

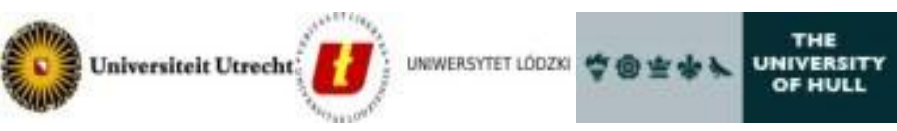




\section{ÍNDICE}

1. CONTEXTUALIZANDO LOS INICIOS: espacio, tiempo, insomnio y el miedo.......... 7

1.1. METODOLOGÍA: la AUTOETNOGRAFIA, desafiando mis inseguridades..... 10

1.2. UN BARRIO LABERÍNTICO: la incertidumbre tras cada esquina............... 14

\subsection{DISCUSIONES TEÓRICAS}

1.3.1. Geografía: Una Idea Imaginada ................................17

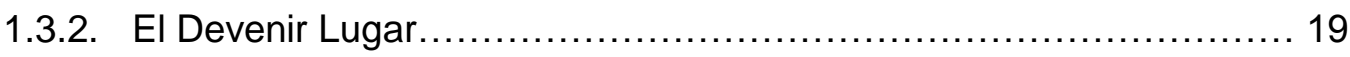

1.3.3. El Derecho a la Ciudad......................................... 21

1.3.4. Público/Productivo vs Privado/Reproductivo: vestigios dicotómicos..... 23

1.3.5. La Arquitectura del Miedo................................... 27

1.3.6. El poder que se filtra en los poros, de donde también brotan sus

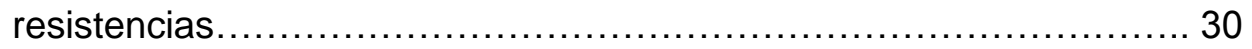

2. AUTOETNOGRAFÍA: Yo, el Espejo y las Otras.

2.1. Cuando no existía el miedo, cuando el todo era la calle $\ldots \ldots \ldots \ldots \ldots \ldots \ldots \ldots . \ldots \ldots 2$

2.2. Las prohibiciones y separaciones: desde el caramelo, a la comunión y a la

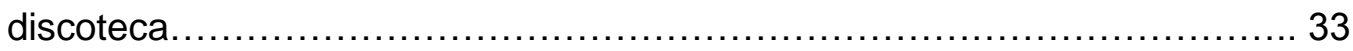

2.3. Ampliando los recorridos, experiencias negadas: los enfrentamientos.......... 37

2.4. Ensanchando el espacio: el encuentro con la diversidad cultural y el acecho del miedo. 39

3. CARTOGRAFÍAS DEL MIEDO: Percepciones en el Albayzín....................... 67

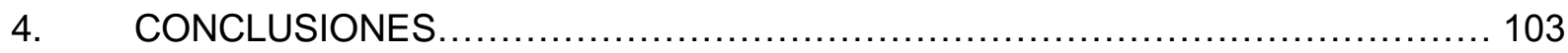

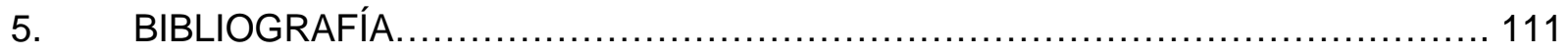

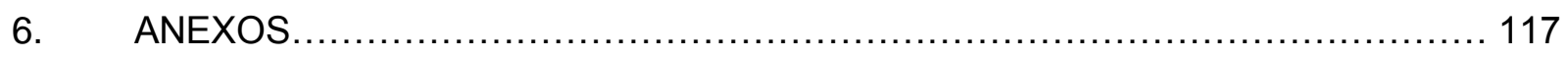




\section{Agradecimientos}

Todas aquellas personas que me han ayudado saben cuanto les agradezco, cuanto valoro el granito de cada unx, esos granos que unas veces más ásperos que otras me han aportado fuerzas.

A Carmen, mi inconmensurable gratitud, ella ha sido quien me ha acompañado en todo momento, a quien le he compartido mis flaquezas, esas noches oscuras de mis adentros, mis inseguridades. Ha hecho de directora, psicóloga y amiga. Toda mi apreciación a su estilo particularizado, suyo, el de ser dinamizadora y creer en la agencia de las personas, lo hace palpable con cada encuentro, una pregunta mía es respondida con una pregunta suya, lo que me ha enseñado, en este proceso continuo, desde hace años, es a preguntar desde abajo, a anticipar la pregunta, a cuestionarme, sin darme respuestas, despejando los matorrales para que yo dibuje mi propio sendero. A Carmen, gracias, sin medida.

A Belén porque también me ha acompañado en este itinerario desde el principio, desde el pasado año, batallando, explorando, regocijándonos, apostando complicidades, cayéndonos y tendiéndonos la mano, las palabras no hacen cuenta a lo que mis adentros gritan.

Agradezco tanto a Julia, quien ha contribuido a la creatividad cromática de este mapa, pero aún más ha sido a otro nivel, a esos cafés sinestésicos en los que me abocaba a una ruptura con mi mente hermética, me abría el cerrojito de la puerta de mi jaula, gracias por tantas aportaciones.

Ni que decir tiene que cada una de las personas que aquí aparecen son las protagonistas, y que ha sido un compartir y reflexionar recíproco, que tras cada entrevista me levantaba con esa persona en la cabeza y me acompañaba durante el día, ninguna fue simple, todas tuvieron su 
carga emocional, arrastrar los miedos de puertas afuera ha sido una aventura cargada de fortalezas.

Y a la persona más importante, mi madre, la misma que me llevó a esto, la que me regaló corsets desde chiquita, todo desde sus mejores ojos, la misma que ha hecho posible que, con su esfuerzo y amor, aprenda a desabrochármelos, a despojarme de tanta cuerda. 


\section{RESUMEN}

Este trabajo pretende desenterrar algunas voces, de personas que viven en el Albayzín, el barrio elegido tanto por su peculiar trazado laberíntico, como por su proceso gentrificador que afecta a la vida social de quienes lo habitan, un barrio vivido de forma distinta por hombres y por mujeres, debido al temor que despierta, un temor subjetivo pero compartido y que tiene efectos en cuanto a moldear rutinas, actividades y ritmos. Me gustaría mostrar como el miedo construye género y espacio, se inscribe en los cuerpos, diferenciándolos genéricamente en cuanto a sus forma de vivirlo, de personificarlo y de enfrentarlo. Me interesa conocer qué es lo que se teme, junto a otros elementos como la personificación del miedo, a quién se teme y en qué lugares, constituyendo así una cartografía del Albayzín transitable y el Albayzín prohibido, junto a la cuestión relativa a las resistencias, qué se hace con lo que se tiene, de qué forma se contesta el miedo. Para ello he llevado a cabo entrevistas y observaciones reflexivas. Cada una muestra como con su bricolaje de acciones y prácticas se relacionan con el espacio y con el miedo de formas muy variadas en algunos casos y muy similares en otros, integrando la idea de que el espacio no es neutro, sino que nos moldea y el miedo constituye una clave de poder que jerarquiza, limita, segrega y excluye. Mi interés es atender a las causas para poder efectuar ciertos cambios en la forma de entender la ciudad que caminamos cada día, la posibilidad de vivirla con mayor felicidad y libertad. 


\section{ABSTRACT}

This research aims to unearth some voices from people who live in Albayzín, the chosen area because of its peculiar labyrinthine delineation as its gentrification process that affect to social dinamics of people who live there, experienced in a different way by women and men due to fear, a subjective one but shared and which shapes routines, activities and paces. I would like to elucidate how fear produces gender and space, it is embodied and gendered experienced regarding to the effect it has and how it is contested. I am interested about how fear is constructed, what frighten us, as well other elements such as who personify it, where it does, creating a cartography from the practicable and prohibited Albayzín, along with resistances, how people respond to fear. It was carry out through interviews and reflexive observations. Each one shows attending to their bricolage of practices the way they relate to fear and space in many diverse ways sometimes and similar in other, taking into account that space is not neutral but shape us and fear constitutes a power element that generate hierarchies, limits, segreation and exclusions. My interest about attending causes is coming with the intention of efectuating changes in the way we understand the city we walk everyday, to experience it with happiness and bigger freedom. 
"hay quien afirma que, de nuevo, la ciudad es la tierra incognita por descubrir, tan fascinante por unxs y temibles por otrxs, como lo fueron en otros tiempos selvas, montañas o desiertos [...]" (Bru y Vic)

\section{CONTEXTUALIZANDO LOS INICIOS: espacio, tiempo, insomnio y el miedo}

Alertada por la necesidad de decidir sobre un tema de tesis, el reloj me va marcando los días, los minutos y ya los segundos restantes, (tiempo que a medida que veo que se me escapa, que se me escurre me hace pensar más en él, en mis deseos de aprehenderlo, de asirme de él, como si estuviese bajo el escrutinio de los hombres grises de Michael Ende) y esta sensación junto a un palpitar de corazón que se va haciendo cada vez menos respetuoso con los ritmos ordenados, provocan una "matanza" de creatividad. El tema decidido de antemano, acerca del control del cuerpo y sexualidad en mujeres gitanas, ya que éste era un tema que había trabajado en el pasado y al que quería darle continuidad, no encuentra espacio en mi motivación, desorientada e inquieta me despierto una noche a las cinco de la mañana en el que este tema del no hallazgo llenaba mi desasosiego, pero esta vez el insomnio me traía un regalo, la idea de cambiar el tema, de trabajar en algo que me moviese por dentro de una forma más visceral. Se me suscita la posibilidad de trabajar en un campo distinto, relativo a una asignatura que estaba cursando en ese momento, Social Geographies of Power and Gender y que verdaderamente me estaba proporcionando un aporte novedoso y alentador, de la mano de la profesora Allaine Cerwonka.

Casualmente al día siguiente, apareció ante mí la noticia de que la Plaza de la Libertad de Granada sería vallada ${ }^{1}$, la plaza que le da nombre, posteriormente, como resultado de la

\footnotetext{
${ }^{1}$ La justificación la da el presidente de la Asociación de Vecinos San Ildefonso: "Hay drogadictos, perros, botellón, de todo menos gente honrada. Las ventanas no se pueden ni abrir por el mal olor que hay y, además, llegan a desnudarse por la noche y se bañan en la fuente. Todo un espectáculo".
} 
ejecución de Mariana Pineda por abogar por la causa liberal y nada más irónico que con las rejas de la antigua cárcel. Esta paradoja me afectaba no sólo a nivel ideológico sino emocional, esa plaza que de tantas experiencias me había plasmado, tantos ratos y risas compartidas, cantes, bailes, protestas, secretos y sueños tuvieron lugar en ella, en unos tiempos en los que el estar en la plaza era la norma, ese lugar de interacción, socialización, flirteos e incluso de lágrimas, de emociones, un lugar con sus tiempos siempre flexibles, siempre posibles, tiempos que a día de hoy competirían con las horas frente a un televisor o el internet, aquellos tiempos en que la vida transcurría en las plazas, en las calles.

Con ambos acontecimientos, la inspiradora asignatura y la noticia arraigante, me planteaba acerca de la construcción y producción de espacios, desde una perspectiva general, geopolítica pero que me llevó a pensar en lo concreto, en la ciudad, en la calle, en mi cotidianeidad, en donde vivo el cada día cuando salgo por la puerta, la forma en que la pienso, la conceptualizo, la practico y la significo. Y como narraré más adelante pensé en el miedo, un elemento limitador, algunas veces paralizante, otras veces, cuando reflexionado, generador de valentía y que como el género y la ciudad también estaba construido social y culturalmente.

Empecé a pensar en el miedo, un algo que se siente más que se piensa, y me cuestionaba todo ese carácter biológico del que está inmiscuido, entendiendo, sin atropellar este carácter de "natural", una respuesta física de nuestros más remotos instintos, también estaba cargada de culturalidad, de significados impuestos, es natural que sintamos miedo pero el dónde se deposita o personifica y el cómo lo vivimos sí forma parte más del constructo y como tal, no es inmanente, es susceptible de cambio.

Pensaba entonces acerca del miedo en el espacio urbano, un miedo concreto en el que se depositan otros miedos, cómo a través de mitos urbanos "se camuflan los más profundos 
sentidos de los social y encuentra como al narrar y narrarse la gente encuentra explicaciones, domestica sus miedos y le pone nombres a la esperanza” (Reguillo.1996: 74). Y hablar acerca de ellos es, quizá, una forma de identificar que dichos temores no se corresponden tanto con el advertido riesgo que en los discursos se transmiten.

Partía de la base de considerar que la ciudad es percibida y vivida de manera distinta por hombres y por mujeres, donde también incurrían otras diferencias como la clase, la edad, la procedencia, la etnia, la adscripción religiosa y por supuesto la identidad sexual. Tenía interés en acercarme a los imaginarios de personas que viven y transitan el Albayzín, rastreando en sus recuerdos las historias que les han contado a modo de advertencias, las leyendas, como han contribuido en la socialización genérica del espacio, en sus subjetividades presentes que le han aportado una forma concreta de relacionarse con los espacios, más constreñida en el caso de las mujeres, (pero también en el caso de quienes no se acotan a los parámetros heteronormativos) en definitiva, cómo el miedo construye el género y construye también el espacio. Para ello he considerado ineludible conocer a qué le tienen miedo algunas de estas voces albayzineras, como cambian de unas a otras, aun dilucidando ese discurso hegemónico que se coló no sólo en lo oral sino también en lo corporal, pero que permeada por las ideas de Foucault me interesa también cómo ahí también surgen sus resistencias, qué hacen con sus miedos, una exaltación a la cultura del contramiedo, un a pesar de que lo vivo, nadie me para los pies.

Tardé un tiempo en reubicar el objeto de estudio pues fue abundante la bibliografía al respecto del miedo, sobre todo desde temas de seguridad en relación con el mobiliario urbano, con la construcción de las ciudades (gated cities, edge cities, etc.) y sus múltiples artefactos de control relacionados con esta cultura del miedo, aunque desde el principio estuve interesada acerca de las resistencias. 
Estando en la distancia del lugar (Budapest) donde estaría ubicado mi objeto de estudio (el Albayzín), leía a nivel general, sin atender a especificidades geográficas, aunque esta bibliografía estaba centrada sobre todo en América latina y EEUU. Fue cuando me moví a Granada cuando me aproximé al barrio, intentando retraerme a ese lugar del extrañamiento aun dentro de lo familiar, observando los espacios públicos, las presencias, usos y ausencias. También me provocó un sentimiento de contradicción entre aquello que leía y me interesaba y su aplicabilidad en este otro contexto, distinto en sus formas y contenidos, aquí veía cómo a pesar de un intento regulador por parte de promotores, de homogeneizar el barrio con un perfil concreto, distinto del que lo había poblado anteriormente, las gentes que se instauraban se resentían, había perfiles de lo más diverso, dotando el barrio de un carácter desafiante a tales intentos, aquí percibía la primera resistencia, el quienes lo habitaban y la forma de hacerlo.

\subsection{Metodología: LA AUTOETNOGRAFIA, DESAFIANDO MIS INSEGURIDADES}

Como Carmen Gregorio manifiesta en su artículo Contribuciones Feministas a Problemas Epistemológicos de la Disciplina Antropológica: Representaciones y Relaciones de Poder, el conocimiento científico se ha entendido, la mayor parte del tiempo, como ese lugar donde se alojaba el rigor científico y lo objetivo, reflejado en la figura del antropólogo, según Scheper Hughes, como si fuese un muñeco de nieve, una representación de la observación de un ser invisible, inerte, de alguna forma, en la que no se filtra ni una centella de emociones y lo que quedaba fuera de ahí no tendría cabida, identificándose más con lo literario que con lo científico y "que llevaba a que la escritura etnográfica fuese despojada de lo experiencial en el encuentro con "lo otro", en pos de la búsqueda del rigor metodológico" (Gregorio:10), hasta que la critica feminista introdujese un prisma nuevo a través del cual mirar, analizar, interpretar y producir: el conocimiento situado, el que dará lugar a las "objetividades encarnadas" que sí incluyen 
aquello que el viejo conocimiento científico excluía, esas áreas subjetivas que tienen lugar durante el proceso etnográfico, los afectos, las pasiones y las reflexiones, que deben contenerse también en lo teórico. Otra forma que dilucida "como el conocimiento es parcial, histórico y no universal".

Y es desde esta perspectiva, la epistemología feminista, donde yo me posiciono, en una forma de hacer trabajo de campo, rastrear, inferir, anotar, interpretar y escribir desde otra mirada, esta que me incluye a mí en la investigación, con mis vivencias, con mi dinamo de sensaciones ${ }^{2}$, mis emociones, mis dudas, mis fervores y mis temores. No puedo separarme de mí misma ni en la forma en la que miro, lo contrario sería un engaño, un despotismo. He de admitir que he llegado aquí después de un proceso de desvinculación de aquella otra forma de producción de conocimiento, sintiendo la inseguridad de llevar a cabo un trabajo autoetnográfico por estar imbuida del paradigma de la objetividad, aún con la vieja idea de mantener distancia respecto al objeto de estudio.

Así, la forma en la que me acerco a la realidad que he pretendido estudiar, indagar en algo tan íntimo como las percepciones individuales en cuanto a los miedos que habitan los cuerpos, ha sido la autoetnografía, un método que incluye la importancia del aspecto subjetivo como susceptible de ser objeto de estudio. Con esta elección trato de darle valor. Lo hago además con el ahínco de tambalear aquellas otras formas de hacer que excluyeron a las mujeres de lo científico, un exponer al muñeco de nieve a temperaturas elevadas con el intento de diluir dicha objetividad enmascarada de cientificidad, una crítica a ese orden social antes impuesto.

En mi trabajo comienzo identificando situaciones en las que se definen y marcan las identidades, los corsets que van construyéndome en femenino. A través de mirarme en ese espejo no me veo solo a mí, también están "las otras", considero es una vivencia compartida,

\footnotetext{
${ }^{2}$ Expresión de Virginia Woolf.
} 
aun siendo vivida individualmente. Más tarde, como diría Jone Miren, trato a la vez de posicionarme en ese entorno social en el que se me marca, en ese y en otros que también me definen, como donde hago trabajo de campo.

$\mathrm{Y}$ aunque me sumerjo en un ejercicio autobiográfico, en el que utilizo mi memoria como un espejo, como dice Jone Miren, en el que se refleja mi identidad a través de los recuerdos forjados de mi infancia, lo considero una etnografía en tanto en cuanto deja de ser personal para convertirse en común, las vivencias en el pueblo eran compartidas, aun sin hablarlo entre nosotras, nos pasaba a casi todas.

En ese indagar en mi memoria registro recuerdos de mis vivencias e introspección de normas, lo que me hará colocarme en una posición de informante, de entrevistada, seré una más.

A partir del Trabajo de Campo presto atención a las estrategias cualitativas que incluyen trece entrevistas en profundidad, procurando recoger la mayor heterogeneidad posible, mujeres y hombres aparecen en ellas, distintas edades, personas de toda la vida del Albayzín y gente llegada no hace tanto. Esta ha sido la forma de acceder a mi objeto de estudio localizado en lo subjetivo, las percepciones acerca del miedo. Llevé a cabo observación participante sólo en algunas zonas, a la que dejé de prestarle más atención en términos de notas, por la prémula de tiempo, zonas que he transitado cotidianamente, con mis gafas inspeccionadoras puestas, zona elegida de camino a casa la mayoría de los días, desde que empecé con el trabajo de campo, intentando encontrarme con estas extrañezas que antes no veía y a la vez me gustaría representar en un mapa esos itinerarios de la ciudad prohibida que las personas entrevistadas me han señalado.

La metodología ha sido muy participativa, no acotada a las entrevistas sino a un resurgir continuo de sensaciones, percepciones y reflexiones acerca de este tema. Tantas, tantas personas fueron entrevistadas, aun sin grabadora, aún sin itinerario de preguntas, se convirtió 
en una conversación recurrente. Inquirí a muchas personas en mi tránsito por el entorno, en mis paseos de observación, no hubo caña sin tapa y sin conversación al respecto, en las que no se tomó nota, pero que habrían sido muy provechosas, sobre todo en términos de percepciones e introspecciones, de contagio de miedos, como en grupos se refuerza esa reproducción de patrones interiorizados, donde se coló el poder, pero también interesante es el cómo cada persona encuentra su estrategia. El cuerpo no es un espacio desdibujado, sobre el que se trazan los procesos sociales, sino que este mismo funciona como carboncillo, delineando dichos procesos. Como diría Mari Luz Esteban en el cuerpo se encarna la estructura social, que a su vez actúa como agente de la construcción social, que a la vez que reproduce dicha estructura, también la resiste. (García, 2010).

Con este estudio ideográfico no pretendo obtener generalizaciones, me interesa el acercarme a las personas en tanto individuxs con sus contextos para comprender sus actitudes y vivencias en torno a este fenómeno del miedo, que como he intentado narrar en primera persona, aunque considero extrapolable a muchas otras, se incorpora en nuestros cuerpos configurando nuestra cartografía sobre la ciudad, la ciudad vivida, percibida y concebida.

Las personas establecemos relaciones con los lugares, relaciones cargadas de emociones y significados y es por este motivo que elijo centrarme en este paisaje urbano, porque me afecta en el tránsito y las reflexiones cotidianas y porque a pesar de ser un lugar en el que se acumulan muchos intereses externos a quienes lo habitan, también se constituye como un lugar, aunque cercano al centro fuera de él, en el que se cuelan las luces cegadoras y las sombras ocultando la reguladora mirada del Panóptico de Bentham y Foucault. 


\subsection{UN BARRIO LABERÍNTICO: la incertidumbre tras cada esquina.}

"Cualquiera piensa en el Albayzín y ¿que viene a la mente?: sus callejones"

El Albayzín, ese entramado de calles estrechas, laberínticas, procedentes del periodo nazarí, donde se encuentran sus casas típicas, los cármenes y sus contrastes con las casas más austeras, con otras vacías ${ }^{4}$, cayéndose a trozos. Por sus paredes cuelgan parras, buganvillas y jazmines, un arrabal era del que ya sólo permanece su simbolismo. Un lugar desregulado dentro del incesante intento de regulación, desregulado respecto a otras partes de la ciudad, en el que muchas de sus memorias siguen conectadas al presente a través del agua de sus aljibes. "El Albayzín presenta seductores encantos que lo hacen el barrio más sugestivo, evocador y atrayente de Granada [...]; La variedad de volúmenes; los constantes cambios de líneas y el abigarrado colorido que ilustra la composición, originan múltiples juegos de términos y, perspectivas que plasman en los más pintorescos y bellísimos paisajes que nuestra mente pueda imaginar" (Seco, 1974:6) Un paisaje impensable para los ojos que nunca lo pudieron contemplar, un paisaje ensoñador que difiere de sus orígenes bélicos, "no es, por tanto, el Albayzín desde sus orígenes un lugar paradisiaco, es un lugar conflictivo" (Alcantud, 135). Marcado por sus murallas que tenían el desafío de defender a quienes dentro se encontraban. Representaban la separación de dos mundos, el adentro del afuera, una representación también del miedo, miedo que ya no es retenido por estas murallas, se transformó y las

\footnotetext{
${ }^{3}$ Una reapropiación personal de una frase de Jacobs, "Think of a city and what comes to mind? Its Sstreets" (Jacobs, 1961:39)

${ }^{4}$ Un tercio de las viviendas están vacías
} 
traspasó. Ya no hay murallas que nos mantengan segurxs ${ }^{5}$, aunque intentemos construir otras relacionadas con los sistemas de seguridad privados. La percepción del barrio actual, no obstante, es ese otro lugar que describía, aunque el vecindario cuenta que esto era un pueblo, que han crecido con sus puertas abiertas, incluso una señora de 77 años, Pepa, me contaba que había un matrimonio al lado de su casa que se sacaban el colchón a la calle en el verano, porque dentro no se podía dormir de la calor. También cuenta cómo el barrio ha cambiado, cómo quienes lo habitaban se trasladaron a barrios como la Chana, el Zaidín o Parque Nueva Granada, porque eran lugares que tenían comodidades, satisfacían básicamente sus necesidades ${ }^{6}$. Barrio con necesidades pero también con vida, con vecindad, algo que cree distinto en esos otros barrios. Considera que desde estos transvases geográficos entre los $60 \mathrm{y}$ los 80 el barrio ha cambiado. Se declaró Patrimonio Cultural en 1984, lo que ha cambiado el sentido de barrio que había pero se ha generado otro, del que se quejan algunas personas pero también ha afectado a que Ixs vecinxs valoren más su barrio, viendo el reflejo de esos otros ojos extranjeros que llegaban aquí deslumbrados con la belleza paisajística, pero lo más importante, con sus tradiciones y sentido de comunidad. El contexto orográfico, sus casas y el ambiente continúan operando "como productores, reproductores y soportes de cultura y de memoria" (Bouzada, 2001:66). No obstante, es un barrio en continuo cambio, en proceso, debido a este carácter revitalizador que lleva aparejado.

En un estudio llevado a cabo en el Albayzín, Estilos de Vida y Revitalización del Espacio Urbano, realizado por Juan Carlos de Pablos y Ligia Sánchez, acerca de los estilos de vida y

\footnotetext{
${ }^{5}$ Utilizaré la " $x$ " para referirme al femenino y al masculino indistintamente, como parte de un lenguaje inclusivo, aun sabiendo que su uso no es admisible normativamente, elijo utilizarlo como cuestionamiento a ese concepto resbaladizo de norma y como un intento de ampliar dichos límites, algo que está vivo no puede estar sometido a fronteras infranqueables.

${ }^{6}$ pues Pepa me contaba como ella misma no tiene cuarto de baño, sí tiene un retrete pero no hay ducha ni lavabo. Paga 10 euros por su casa mensualmente pero ahora la quieren vender y ella está preocupada porque no sabe de qué forma le repercutirá, ya que escuchó que a la mayoría de las personas que han estado en una situación similar, las han engañado.
} 
cómo éstos repercuten en la configuración y en la reproducción del espacio urbano, se distinguen dos grupos como forma de englobar la heterogeneidad existente: por un lado las personas pobladoras originarias del barrio y por otro las personas llegadas después de los últimos quince años, con estilos de vida y formas de vivir el barrio de manera diversa. En una frase se recoge la principal diferencia entre ambos respecto al significado del barrio y es que para mientras este último grupo recién llegado "el barrio es el lugar en el que se vive, se ofrece más o menos y al que se le dedica más o menos, los albaicineros de siempre son el barrio" (De Pablos y Ligia Sánchez, 2003: 26)

Sus gentes, tan variadas, no hay más que darse una vuelta por la plaza larga, para ver el torbellino de diversidad que este escenario le confiere, gente local, del Albayzín de siempre, gitanxs, senegaleses, magrebíes, gentes del gremio musical, de la artesanía, estudiantes de muchas procedencias distintas gente que vive en las cuevas y hace su vida en el barrio, turistas que van y vienen, repartidores de otras partes de la ciudad, el Albayzín es un puente que se abre en muchas direcciones, también hacia la ciudad, aunque esto ha cambiado con el tiempo, hasta no hace mucho el barrio gozaba de mala fama, muchas han sido las personas del Zaidín y de la Chana ${ }^{7}$, entre otros barrios, que nunca visitaron sus calles pedregosas. La idea subyacente en esos otros lugares es que éste era un barrio lejano, no en distancia sino en costumbres, un barrio inseguro, según me comentaron varias voces. Diría Rossana Reguillo (1996) que esta estigmatización sobre grupos, individuxs y lugares como peligrosos emanaría de un imaginario que asocia "lo peligroso" a "lo pobre". Una idea contradictoria con aquella otra de resplandor con la que artistas, escritores y extranjerxs, deslumbrados por sus casas blancas escurriéndose montaña abajo, los miradores por los que asomaba la Alhambra y la Vega, San Miguel con sus cuevas, sus gentes, permearon el lugar. El Albayzín, aun con su proceso de revitalización llevado a cabo desde los años 90 y su revalorización cultural y simbólica, continúa

\footnotetext{
${ }^{7}$ Tal vez porque allí iban las personas procedentes de este barrio, contando acerca de las miserias que padecían.
} 
siendo un lugar con gran diferenciación interna. Como se han quejado algunas de las personas encuestadas, las ayudas para reformar la casa se las concedieron también a quienes mejor situación económica ostentaban y muchas de las casas necesitadas se quedaron sin ellas.

La topografía del Albayzín, hace el miedo siempre visible, a cada escalón, aún las esquinas más recónditas, con sus luces tenues y románticas, las lentes con las que muchas personas caminamos se regulan desde el miedo. No hay distinción respecto a la percepción del miedo entre estos dos grupos diferenciales que ese estudio presenta, a pesar de que conceptualizan el espacio con diferentes ópticas ${ }^{8}$. He querido introducir más diversidad en las personas recogidas, las que iré describiendo cuando me vaya refiriendo a ellas en el apartado de las cartografías del Albayzín.

En esta dificultad que apuntaba anteriormente respecto al intento de delimitar mi objeto de estudio me sumergí en diferentes lecturas sobre género, espacio y miedo, traeré aquí algunas de las discusiones teóricas relevantes en la consecución de tal propósito.

\subsection{DISCUSIONES TEÓRICAS}

\subsubsection{Geografía: Una Idea Imaginada}

Respecto al moverse en el espacio y sentirlo, cuenta más lo que se observa a priori, en ese flechazo visual, lo que se intuye, lo que se insinúa, lo que palpita, que lo que se sabe, y en este consenso de apariencias y apreciaciones se construirá socialmente la realidad. (Delgado.

\footnotetext{
${ }^{8}$ Mientras que para uno es un espacio asociado a la afectividad, donde las familias y la vecindad constituyen un eje básico, siendo aquí donde se genera lo lúdico y que contempla al turismo como un recurso que consume en el barrio, el otro, lo significa como un espacio privilegiado por sus características, le da más importancia a la privacidad aunque también valora las relaciones con sus gentes, lo lúdico se extiende fuera de esta zona y entiende el turismo como un elemento perturbador de la tranquilidad que no aporta muchos recursos al barrio.
} 
2007). Desde los años 60, las ciencias sociales se interesaron en la percepción subjetiva de la realidad (Geografía de la Percepción), manifestando cómo nuestra experiencia personal llega a conformar nuestra realidad y esto constituyó un cambio de perspectiva ya que "durante siglos el espacio 'se descubría', se cartografiaba y se estudiaba. Era una realidad objetiva y nadie se planteaba este carácter subjetivo" (Vara. 2010:338). Se descubrió que Ixs individuxs y los grupos sociales poseen una percepción propia de la realidad en función de sus valores culturales, sus experiencias y sus aspiraciones, elementos que llevan a edificar un universo en el que cada persona se coloca en el centro y desde aquí se organiza tomando como base la referencia más cercana, de la que se tiene una información más real, más tangible (Millán. 2004). Me interesa esta perspectiva como una herramienta para analizar las relaciones entre ideología y representación (Goonewardena. 2005, en Vara. 2010:340)

La ciudad es aquello que no puede ser alcanzado con nuestra mirada, tampoco un conjunto de imágenes o representaciones podrían otorgarnos una foto global, pues esta estaría impermeabilizada de lo emocional, característica que está presente en la vivencia de la ciudad. Tampoco sus elementos inamovibles podrían concedernos esa imagen de la ciudad. Lo legible de la ciudad depende de cómo se integren sus barrios, sus monumentos, su transporte, esto nos remitirá un esquema mental, así parece que la ciudad se entendería como la interacción de ambos, lo que la ciudad es en sí y las emociones aunadas a ésta, lo que hay y lo que es percibido por sus habitantes.

El área percibida en un estudio en los Ángeles mostró que era menor entre mujeres que trabajaban fuera de casa respecto a mujeres que trabajaban dentro del hogar (Sabaté, Rodríguez y Díaz, 1995: 289), ya que aquellas disponían de menor tiempo para compatibilizar la jornada de trabajo y familiar, sin quedarle apenas tiempo para lo personal. Los hombres mantenían relaciones con el espacio de una manera más ancha, no estaban acotados a la circunferencia doméstica, sus relaciones estaban dispersas mientras que las casadas que 
trabajaban en casa sí se relacionaban más con su barrio, relaciones también ausentes para las que trabajaban fuera.

Otro estudio en Segovia muestra cómo mujeres y hombres nos movemos por distintos sitios, con distintos límites y bordes, percepciones que cambian en función del nivel socio-económico, el nivel de instrucción y la edad. Las personas mayores se mueven de manera más reducida, como cabe esperar y las mujeres en buena posición socio-económica no varían tanto de con los hombres en la misma posición (los recorridos, no la percepción) (p.291).

La percepción del miedo está permeando nuestra forma de movernos, transitar, de relacionarnos en y con los espacios y en definitiva están cambiando nuestra forma de contemplar el mundo, nuestro mundo cercano, al que nos enfrentamos cada día cuando abrimos la puerta de nuestra casa y nos penetramos en la ciudad. Continuando con el contexto mexicano, Reguillo (1998) apunta que la sensación de peligro decrece cuando esa área es conocida, pero esta territorialización se complejiza cuando se anexionan los datos socioeconómicos, que vuelve a zonificar como seguro no sólo lo conocido sino donde es invisible los trazos de pobreza. El miedo es pues el que opera, en base a creencias, en el mapa transitable de la ciudad.

\subsubsection{El Devenir Lugar}

Existen otras formas de experimentar la ciudad con distintos ojos, como los de la persona turista, que llega a la ciudad, recorre ciertos hitos importantes recomendados en la guía turística o la persona mochilera, que probablemente se abocará a lugares más "reales", más inusuales para un turista, que anhela vivir la ciudad de una forma más tangible, más en contacto con el fluir y el transitar cotidiano de la ciudad, aunque solo sean por unas horas, a la mañana siguiente amanecerá en otra ciudad u otro país, se encuadrarían dentro de los que 
Manuel Delgado ha denominado como identidades nómadas, pudiendo ser éstas étnicas (gitanxs, quinquis ${ }^{9} \mathrm{o}$ mercheros $^{10}$.), místicas (peregrinos $\mathrm{o}$ personas en sus búsquedas espirituales) o profesionales (circenses, comerciantes, trabajadorxs aéreos). También otros como hippies o travellers, que tienen experiencias geográficas múltiples, viviendo por cortos periodos en diversas ciudades/países, trabajando en espectáculos callejeros o trabajos temporales, hasta las personas inmigrantes. (Delgado. 2007). "Todos aquellos que, voluntariamente o no, van de un lado a otro, viviendo la experiencia de esa no-ciudad que son todas las ciudades por las que transitan sin detenerse apenas lo justo para reposar o llevar a cabo un propósito concreto." (Delgado. 2007: 75).Este vagabundear por el mundo, estas situaciones que te hacen tener ante los ojos un tapiz sin pintar, sin significado, con percepciones, observaciones y vivencias claramente contrastables, inéditas, extrañas, podrían aportar ricas aportaciones a este deambular teórico, antes de que la familiaridad te haya imbuido y ya no sea tan identificable la diferencia, el espacio se aproxime a lo cotidiano y ya se empiece a mirar el lugar además de con los ojos con las emociones, el sentir de aquel evento sucedido en esa noche de invierno, donde el suelo y las ruedas de la bici se vierten de una tupida capa de nieve, aquel indomable palpitar que me acontece cuando cruzo el puente, que ya no es un lugar con detalles descosidos en la extrañeza sino un conector de significados, de vivencias, de sentimientos. Esto daría lugar a la idea del Sentido de Lugar que no es único como diría Rose (1995:88), un término acuñado por la geografía humanista primero y la cultural después, que considera el lugar como una construcción social o una subjetivización de los lugares y permite analizar la forma como el espacio, entendido como algo abstracto y genérico, se convierte en lugar gracias a la experiencia y a la acción de los individuos que, viviéndolo cotidianamente, lo humanizan y llenan de contenidos y significados. (Massey. 1995). Los

\footnotetext{
${ }^{9}$ O quinquilleros, un grupo social que comparte rasgos comunes con el colectivo gitano pero tienen distinta procedencia. Se dedicaban a la quincalla (a vender metales) y hablaban distinta lengua.

${ }^{10}$ Se dice de quien tiene padre gitano y madre paya o viceversa.
} 
lugares quedan investidos de significado por ser el foco de emociones y sentimientos personales. Las relaciones que se han superpuesto durante el tiempo en un lugar producen una intensa "sensación de vida" (Hall, 1995: 180).

Gillian Rose (1995) siguiendo a Massey, apunta el sentido del lugar como un proceso que establece la diferencia social desde la demarcación de límites espaciales, límites que revelan las estructuras subyacentes de poder. Los sentidos del lugar están íntimamente ligados a la desigualdad, la que se inscribe en adscripciones étnicas, de género y de clase, caracterizado por un reparto ordenado del espacio y con esta espacialización de las diferencias se construyen topologías sociales en las que se dictan la legitimidad del derecho a la ciudad (Lefebvre, 2009, en Núñez).

\subsubsection{El Derecho a la Ciudad}

En cuanto al uso de la ciudad, desde una perspectiva anti-neoliberal, se pensó en invertir los poderes, la ciudad como servicio de quienes la habitan y no habitantes bajo el poder de la ciudad (Purcell, en Sugranyes y Mathivet), es lo que se llamó el Derecho a la Ciudad, una propuesta política de Lefebvre (1968) que reivindica la apropiación de la ciudad por parte de la ciudadanía, quienes serían los elementos principales y la ciudad el escenario que hace posible la constitución de la vida colectiva, la pertenencia a una comunidad política, no ya en base a la ciudadanía legal, formal, sino basada en la habitancia. Dentro de este concepto incluye: el derecho a apropiarse del espacio urbano, el derecho de uso pleno y el derecho a la participación (toma de decisiones en la producción del espacio urbano). David Harvey añadiría a este derecho: un lugar de posibilidades, de participación, de acceso y de sueños. Aunque Henri incluye el derecho a la diferencia dentro de este concepto, diferencias a esas categorías establecidas por un poder homogeneizador, sin embargo, se centra más en el "ser" más que en 
la diferencia y no cuestiona lo referente a identidades y género, así no contempla esta dificultad para el ejercicio de este derecho. El género está ausente en este modelo, junto con otros aspectos de la identidad

El Derecho a la Ciudad de Lefebvre se ciñe al ámbito de lo público, la oeuvre, percibida desde la crítica feminista como ese lugar donde domina un hombre blanco, heterosexual, de clase media-alta. En las ciudades (occidentales o no) las mujeres no pueden hacer uso de las plazas y calles, si están solas, como nos recuerda Massey (1994) y en algunas culturas no pueden pasear por ellas bajo ninguna circunstancia, ya que pertenecen a la esfera "privada" según Fenster, quien desvela en un estudio llevado a cabo con mujeres en Londres y Jerusalén que las mujeres no ejercen ese Derecho a uso aun ni en el espacio privado. Una de las mujeres comenta cómo no se siente cómoda ni perteneciente a su hogar, el decorado y el uso es acorde a su pareja sin que ella esté implicada. El control del hogar no tiene por qué ser extrapolado a la ciudad, así, otra de las mujeres comenta cómo relaciones patriarcales muy estrictas en casa la hacen que sienta un sentimiento de pertenencia mayor a la ciudad, constituye éste un espacio de liberación, es ese lugar en el que ella se despoja de todo ese control que su familia ejerce sobre ella. Encuentran, otras mujeres, este espacio de la calle como un espacio donde negociar su sentido de pertenencia. Para Michel de Certeau la pertenencia es un sentimiento que se experimenta a través del tiempo de la vida cotidiana y del uso de los espacios, dando lugar a un proceso de territorialización y apropiación, en el que "la pertenencia y el cariño se construyen sobre la base del conocimiento, el recuerdo y las experiencias físicas de carácter íntimo acumuladas a partir del uso cotidiano principalmente a partir de la acción de caminar" (De Certeau, en Fenster. 2010:72).

Hemos de asumir que de la misma manera que todas las personas somos construcciones sociales, a través de categorías de género, entre otras, también lo son los espacios, como diría Koskela (1999), el espacio también es una producción social y simplemente no existe. Igual 
que las personas no somos neutras tampoco lo son los espacios y es aquí donde tenemos que incluir el análisis de género (un análisis que examine las desigualdades, identifique y satisfaga las necesidades), pues las prácticas de mujeres y hombres en las ciudades están moldeadas por estas interpretaciones sociales de género y espacio. El espacio es construido por las prácticas sociales que en él toman parte, por tanto es un producto a su vez, de estas relaciones sociales y de poder. (Koskela, 1999, en Buckingham, S., 2010).

El miedo y la inseguridad que muchas mujeres experimentan en la calle, en el transporte público y en los parques limita el Derecho a la Ciudad (Valentine, 1998 en Fenster, 2010), es identificado también con el diseño de los espacios urbanos, los que han sido denominados por algunas mujeres como una "trampa planificada", espacios planificados por hombres sin tener en cuenta la sensibilidad de los géneros, sin prestar atención a que las mujeres tienen ese miedo al arrebatamiento sexual de sus cuerpos que los hombres no conocen. Los parques son percibidos como "áreas masculinas hostiles", "el miedo es un sentimiento que transforma los parques urbanos en espacios prohibidos después de cierta hora del día” (Fenster. 2010:77). Madge (1997, en Fenster, 2010) advierte esta falta de uso afecta a todas las personas, también a hombres.

Fenster (2010) asevera que, se dan muchas prácticas cotidianas que excluyen del Derecho a la Ciudad basadas en el género, como consecuencia del miedo y de normas culturales, prácticas dictadas por el significado simbólico-cultural de los espacios.

\subsubsection{Público/Productivo vs Privado/Reproductivo: vestigios dicotómicos}


A finales del S. XIX las mujeres de clase media fueron consignadas a la esfera privada, sino en la praxis sí en la ideología. Lo relativo al mundo público del trabajo, los bares y cafés ${ }^{11}$, la vida de la ciudad les fue prohibida pero la realidad es que las mujeres también pasaban tiempo en lo público, doméstico pero yendo de compras, ese espacio que sí les estaba permitido, resultó exitoso el auge por las compras, las modas, a pesar de que éstas formaban parte del espacio público eran vistas como una prolongación de lo privado. No importaba si las mujeres eran acosadas, molestadas, miradas fijamente o agredidas porque para la ideología de la época ellas estaban aun en el hogar (Wilson, 2001), contempladas entonces como vehículos de consumo. Las ropas que compraban eran propiedad del marido, como también lo era simbólicamente la mujer que las llevaba. Las ropas se elegían en función de la categoría social del marido, hecho éste que todavía sigue sucediendo.

Michelle Rosaldo (1979) apuntaba cómo la desigualdad de las mujeres reside en la dicotomía público/privado, que designó roles inamovibles con sus tareas asociadas, a ellas se les adjudicaba todo aquello relacionado con la domesticidad, funciones que aun siguen vivas en algunas esferas, en algunos lugares, en algunas prácticas, en las sutilezas, como diría Teresa del Valle, sigue vivo en un lenguaje que proyecta a cada unx en su espacio y a través de otros múltiples detalles no observados en los discursos pero sí en las prácticas, los que hacen referencia a la forma en la que unos y otras se mueven por los espacios, mi madre siempre con prisa cuando está en el afuera y como mi madre muchas otras mujeres que sienten que su espacio, suyo, está en la casa. Soledad Murillo hacía una crítica a este término de privado, afirmando que las mujeres no han tenido jamás un espacio privado, el que Virginia Woolf contemplaba como aquel donde tiene cabida el tiempo libre, las aficiones, la lectura, ... del que los hombres sí han dispuesto. Sería así más apropiado hablar de espacio doméstico, ya que el

\footnotetext{
${ }^{11}$ Más tarde se abren cafés destinados a mujeres.
} 
otro conllevaría contradicciones, aunque me siga refiriendo a este espacio como privado tengo en cuenta esta reflexión.

Hay una idea introspectada de que las mujeres y el espacio público no son las mejores compañeras. Todavía ahí dentro, en nuestra forma de pensar, actuar, esperar, está la idea de que ése es un espacio inapetente para las mujeres, como si aún no lo hubiésemos "conquistado". Siempre nos han apartado de la calle, nos han recluido mental y simbólicamente a espacios cerrados. Serán tantas y tan sutiles las maneras en que han intentado lograr tal efecto, por mencionar alguno, la asociación del uso del espacio público por parte de mujeres con su consiguiente apelativo, quienes estaban ahí fuera eran las mujeres públicas, las prostitutas mientras que ellos no se han acogido a categorías al respecto, ellos fuera de todo apelativo.

Según Del Valle, tratar de encasillar a mujeres y hombres en estos espacios es una forma de acorralarles, cercarles, no reconociendo que los espacios no son impermeables, sobre todo desde la consideración de que las nuevas tecnologías han invertido estos denominativos, ya no podemos hablar de estos espacios como distintos y separados, cada vez son más las personas que trabajan en casa, internet les lleva a lugares remotos sin moverse desde la vivienda y desde ahí se gestionan y crean redes muy distantes de aquel viejo concepto de privado. A la vez que lo domestico se organiza en muchas ocasiones desde lo público, desde el trabajo.

La planificación urbana sí ha tenido en cuenta dicha dicotomía, según Martínez (2008) los espacios urbanos se han diseñado para valorar la producción y menospreciar la reproducción, lo que obstaculiza aún más cuando se experimentan los dos ámbitos. No puede construirse una ciudad neutra porque se infringirían las necesidades de muchas personas que no estarían incluidas en esa planificación normativa, el derecho general no puede obviar las particularidades, el Derecho a la Ciudad para todxs implica pluralidad más que neutralidad. 
El espacio moldea nuestras experiencias de vida y las interacciones sociales que en él tienen lugar.

En una encuesta sobre percepciones y usos del espacio urbano en Guadalajara (México) ${ }^{12}$, se pretendía examinar la consistencia de los significados de la ciudad y elaborar un mapa de los imaginarios con los que se vive y se transita la ciudad. Se halló que existe una distancia entre la ciudad vivida que se encoge cada vez más y la ciudad como sistema que se describe como un todo caótico y amenazante y para organizar dicho caos, Ixs actorxs sociales conforman, mediante representaciones simbólicas e itinerarios elegidos un espacio urbano manejable. Este transitar se somete, más que a una economía espacial, a lecturas simbólicas del espacio: una calle puede significar la muga entre lo seguro y lo inseguro, un parque, puede convertirse en la representación del mal, un barrio en un suelo escurridizo. Estos lugares revelados como precipitadores de riesgo inminente son las periferias, los barrios pobres y populares, los mercados tradicionales y la zona roja. Las personas encuestadas admitieron no haber estado nunca allí. Y a estos lugares les anexionan figuras peligrosas como serían el "cholo" (relacionado con las bandas), la policía, el narco, el asaltante o el violador. Y así, ordenan sus universos geográficos, sus cartografías del miedo y fabrican dioses y demonios. "La ciudad es exceso, perdición, pero esencialmente peligro” (Reguillo, 1998:10). La representación del espacio urbano se muestra, según Reguillo, desde una perspectiva masculina, en la que los hombres ostentan lo público, el afuera, como resistentes a los peligros que éste concierne, mientras que las mujeres y niñxs son vistxs como más susceptibles y deben quedar bajo el amparo de lo privado, la juventud, sin embargo deben ser escudriñada continuamente.

Según Fhara Ghannam, en su estudio sobre el Cairo, remarca que el mundo árabe se subdivide dicotómicamente entre un espacio público que pertenece a los hombres, el universo

\footnotetext{
${ }^{12}$ Encuesta sobre Percepciones y Usos del Espacio Urbano en Guadalajara, Seminario de Cultura Urbana del ITESO, 1995.
} 
de la religión y el poder y el privado, que concierne a las mujeres, donde se cobija la sexualidad y la familia. El cruce de un espacio a otro se hace efectivo para las mujeres sólo de manera material, pues simbólicamente siguen refugiadas en su espacio privado, a través del velo, que deja a la mujer "invisible" en la calle (Mernissi, 1987:143).

Parece que lo público es definido por los varones, aquel lugar en el que ellos se hallan, mientras que las mujeres siempre se hallan en el privado, no es el espacio quien les construye sino que ya van cargados con la categoría de espacio al que pertenecen, así mientras los hombres están sentados en algún lugar de la calle son considerados como parte de lo público, las mujeres que cargan agua en el pueblo son percibidas como parte de lo privado (Gilsenan, 1982). No sólo cuando cargan el agua, sino que casi todas sus actividades están asociadas a éste, la compra en el mercado, la visita al médico, todos ellos comportan una extensión de lo doméstico. Para abreviar, las mujeres son vistas constantemente como privatizadoras de lo público (Ghannam, 2002:91).

Según la autora, esta diferenciación de esferas no es tan rígida y hay que inspeccionar en quien define estos espacios, a la vez de quien, cuando, porqué ciertos espacios se incentivan y otros se evitan y por quien se pueden alterar, incluyendo esta categoría de género pero también edad. Es evidente que las mujeres sufren más restricciones, pero también los chicos jóvenes.

\subsubsection{La Arquitectura Del Miedo}

Susana Reguillo advierte que nuestros miedos se están reconfigurando en base a tres factores: por un lado, la globalización financiera que ha provocado la exclusión económica de muchos 
países que se han abocado a mayor pobreza y flujos migratorios, por otro, la mundialización de la cultura que ha reunido en los mismos lugares culturas ${ }^{13}$ tan variadas como remotas y que gracias a dispositivos tecnológicos, como la televisión, han producido un efecto de inmediatez, y finalmente, el descrédito de la política como espacio para regular el pacto social. Las instituciones no pueden garantizar respuestas a los desafíos actuales. Se ha generado un sentimiento de inseguridad y miedo procedente de esta carencia de protección (Svampa, 2004 en Sánchez y Merino, 2007).Como sostiene Castel, la sensación de inseguridad es el "efecto de un desfase entre una expectativa socialmente construida de protecciones y las capacidades efectivas de una sociedad dada para ponerlas en funcionamiento" (2004: 13).

Sergio Merino y María Marcela Sánchez añaden que el impacto del modelo político y social provoca un aumento de exclusiones y de migraciones forzadas, de pobreza, de precarización de empleo, de violencias sociales, entre otras, y cuando todo esto concurre en un lugar se crean también nuevas expresiones sociales, relaciones con Ixs otrxs y formas de vivir, lo que a su vez aboca a nuevos sistemas de protección, he aquí la seguridad privada, que construye barrios privados o urbanizaciones amuralladas (gated cities), los cuales aumentan las desigualdades sociales. La inseguridad se materializaría en lo que Bauman ha llamado el cuerpo de los "superfluos" o Castel "las nuevas clases peligrosas", como inmigrantes, que se perciben como imposibles de asimilar, lo que supone un retroceso en la escala social de las clases ya adaptadas y aquí se refleja sus miedos, los que repercuten en esta "Arquitectura del Miedo" en la que se busca la mayor homogeneidad y privación de espontaneidad, lugares inertes que dan lugar a una segregación espacial, quien no está en un gueto está en el otro, dando lugar a un odio que Bauman ha llamado "Mixofobia".

\footnotetext{
${ }^{13}$ Está resultando fácil a la gente, debido a los avances tecnológicos, mantener relaciones entre la cultura y el lugar. La gente viviendo en otros países diferentes a los suyos originarios se mantienen aun vinculados a estos, respecto a lo que allí ocurre gracias a la proliferación de tecnologías de comunicación. (Massey\&Prike, 1999)
} 
Los inmigrantes que según Manuel Delgado, deberían serle concedidos los mismos derechos, ya que según su máxima todxs somos inmigrantes en el espacio público aunque compartamos la ilusión de pensar que somos indígenas de algún sitio, en la calle todxs vamos de paso, como diría la corriente interaccionista "la calle es el dominio de la alteridad generalizada" todo el mundo es el otro, cualquiera puede ser nuestro peor enemigo o nuestro futuro amor y la noche, ofrece tanto una inmensa catástrofe como la más inaudita de las emancipaciones, un universo rebozante de incertezas. La calle jamás podrá ser controlada, es la antiutopía pese a los intentos de Ixs urbanistas de crear una utopía.

La seguridad ha sido apuntada en muchas ciudades como una de las más graves problemáticas que preocupan a la población.

La ciudad constituye un complejo escenario en el que las redes sociales están entretejidas en piezas que están cada vez más separadas, aisladas, desvertebradas y desintegradas debido al modo de interacción en ellas, lo cual provoca segregación, separación, espacios públicos cada vez menos públicos, enrejados, espacios cargados de violencia, peligro que real o no, nada cambia ya que las consecuencias son las mismas. "La diferencia entre ser perseguido por dragones o por el imaginario no modifica nada la situación. Aún menos modifica a los dragones. No existen, esto es lo único que sabemos acerca de la existencia de dragones" (Abelardo Castillo, Crónica de un iniciado).

Estamos forjando un urbanismo de recintos vallados, de plazas asfaltadas y con artefactos incómodos que no contemplan el acoger, la invitación, ni el afecto, lugares duros que no invitan a permanecer, de centros comerciales y de quehaceres que implican desplazamientos privados por autopistas, esos lugares utilitarios para muchas personas y que surten de poca satisfacción que moldean los patrones cotidianos ajustándolos a unas supuestas necesidades impuestas desde poderes externos que nos hacen asimilarnos a ellas, identificarlas como nuestras. 
Aunque todo poder con la intención de ejercerse con efectividad tiene una capacidad mutativa imparable. En esta sociedad de control, los muros, las rejas y las cerraduras están siendo sustituidas por otras formas invisibles de control: contraseñas, tarjetas de crédito, registros de datos e información digital, otras formas de transitar por los espacios, lo que Marc Augé identificaría con los no-lugares, lugares de tránsito que no tienen importancia de ser considerados lugares, tales como las autovías, los aeropuertos, los supermercados, lugares no habitables, sólo para transitarlos, donde el ser humano es anónimo y la interacción se mide en términos de consumo, lugares lineales, fáciles de conducir, ideados para una nueva forma de moverse, no sólo materialmente, también mentalmente y como se trata de recorridos se miden en unidades de tiempo y un ejemplo de ello son los vuelos intercontinentales que van ofreciendo una visión detallada de por dónde se va pasando a cada instante, incluso acompañada de una explicación por parte del comandante: “a la derecha del avión, pueden ver la ciudad de Lisboa. De hecho no se percibe nada: es espectáculo, una vez más, sólo es una idea, una palabra" (Damiano, Patricia). Las personas usuarias de los no-lugares siempre están obligadas a probar su inocencia, sólo encuentran su identidad en el control. Tampoco construye una identidad singular ni acarrea interacción, pero sí soledad y similitud al resto, en este hacer como los demás la gente se encuentra a sí misma.

\subsubsection{El poder que se filtra en los poros, de donde también brotan sus resistencias}

Foucault describe dos modelos de poder: el de la peste que se ejercita desde la exclusión y el de la lepra que se logra desde el control (Foucault. 2001: 55-59). El primero se caracteriza por la disciplina, el espacio es hermético, vigilado, controlado y con sus estrategias individualizadoras. Se asignan los lugares funcionalmente, las mujeres, las personas locas y los estudiantes, cada persona en su sitio. El segundo, opuesto a éste, separa a las personas 
dicotómicamente en leprosos y no leprosos y a los del segundo grupo se les expulsa al "afuera", fuera de extramuros, fuera del ejercicio de la ciudadanía. Estoy pensando en los pobres, en las personas inmigrantes, en las trabajadoras sexuales, aunque bien creo que se pueden utilizar estos modelos aunque parezcan opuestos, primero se divide, se separa, se excluye, después se ejercita el control individualizado con el interés de conocer las formas de ser más efectivo en dicho control.

Manuel Delgado expone que no se ha sabido siempre reconocer cómo la maquinaria del poder se ha colado en nuestros cuerpos ejerciendo una dominación que ya no emana de una instancia divina o humana externa, sino de una voz autoritaria que se escucha desde dentro y no puede ser de ninguna forma obviada. "Esa fetichización del yo hace más tolerables las relaciones de sometimiento, interioriza la represión y se naturaliza como artefacto de control que, por mucho que se aparezca como fuente de imperativos éticos, no suele ser otra cosa que un dispositivo de disciplina social y políticamente determinado”. (Delgado, 2007:55).

En cuanto a la función de los mecanismos de construcción del miedo María Naredo (2010:83) opina que "la inseguridad de las mujeres es un ingrediente básico para el mantenimiento del estatus quo de las relaciones de dominación patriarcal”. Koskela (1999) añadiría que asumir el miedo y limitar nuestros movimientos en función de éste no hacen más que darle contundencia a la voz dominante masculina sobre el espacio.

Las mujeres que se comportan de manera menos insegura son aquellas que se sienten más en control de sí mismas y de sus vidas. La confianza se construye atendiendo a los recursos económicos, sociales y culturales, pero también sobre la base de la disposición y reforzamiento para correr riesgos más que para evadirlos, asumir riesgos crea confianza. (Naredo, 2010).

Mari Luz Esteban tomando el concepto de embodiment de Thomas Csordas, expresa cómo es en el cuerpo donde se encarna la estructura social, actuando éste como agente en la 
construcción social que la reproduce pero a la que también se resiste. (García, 2010). Tememos y reproducimos lo que tememos pero también resistimos y contestamos, como diría Foucault, allá donde hay poder encontramos también sus resistencias.

\section{AUTOETNOGRAFÍA: YO, EL ESPEJO Y LAS OTRAS.}

\subsection{Cuando no existía el miedo, cuando el todo era la calle}

He experimentado una gran diferencia en cuanto a las vivencias callejeras, a ese transcurrir en la esfera exterior, el afuera, desde el entonces hasta el ahora. Acostumbrada a las usos rurales de un estar siempre en la calle, a la casa se iba a comer y a dormir y en mi caso no siempre a comer, muchas veces hasta comía en la calle, la gente se sentaba al fresco en la puerta de sus casas y el dormir siempre se hacía con la puerta sin cerrar con llave. No había nada que robar en ella, tampoco había miedo. Recuerdo que no había tanta diferencia entre el afuera y el adentro, el tránsito era muy espontáneo, sin un gran contraste, utilizaba la calle como una extensión de la casa y la casa como continuación de la calle.

Los espacios dentro de la casa tampoco estaban definidos funcionalmente de manera tajante, no en mi caso ni en el de mis amigas de la calle. A veces comía en la sala, otras en el escalón de la puerta, como no teníamos ducha y el patio para mí era demasiado frio para ducharme lo hacía en la sala, dentro de un barreño, una foto que a ojos de Mary Douglas (2003) se identificaría como un lugar impuro, no por cuestiones higiénicas sino simbólicas, ese acto está fuera de lugar, el baño es el lugar adecuado para eso y la sala cumple otras funciones, cualquier violación a estos criterios lo catalogaría de contaminante y peligroso.

Eran tantas las horas que permanecíamos en ella que me permeó de un gusto extraordinario por este lugar, la calle era un lugar familiar, mi lugar, donde más confortable me sentía. 
Cuando pienso en el primer recuerdo que tengo de mi existencia, lo recuerdo en la acera, amarrada de un cordón por mi cintura y a la ventana, me recuerdo pataleando, intentando escaparme a la carretera, no llegaría a los tres años y ya encontraba ese poder magnetizante en la calle.

Los juegos casi siempre estaban acompañados de este espacio, el exterior, excepto cuando llovía que nos trasladábamos dentro, solía ser un juego grupal, o al menos implicaba a dos personas, interacción. Aun cuando estaba sola y dentro revertía el espacio conforme a mis necesidades de juego, las sillas satisfacían mi apetencia de jugar al elástico por ejemplo, aunque los mayores recuerdos están afuera, jugando al escondite, preparando ungüentos, disfrazándonos e interpretando roles de la vida adulta, cortando la calle al tráfico, patinando sobre tubos de desagüe... todas las ocurrencias eran posible en un contexto flexible, en el que niñas y niños gozábamos de bastante libertad, la única prohibición que tenía era la de aceptar un caramelo de un extraño, algo anacrónico y que provoca risa a día de hoy.

\subsection{Las prohibiciones y separaciones: desde el caramelo, a la comunión y a la discoteca}

Las niñas y los niños jugábamos juntos, no recuerdo mucha diferencia en nuestros juguetes, sí puedo recordar cuando empecé el colegio y a mí y a mi amigo nos pusieron a jugar a cosas distintas, yo con las muñecas y él con otra cosa que ya tampoco recuerdo, pero sí recuerdo nuestra separación aun dentro del mismo aula, yo andaba atenta más a nuestra separación que a lo que estaba jugando, aunque pronto entré a formar parte de ese universo, a naturalizar esa diferencia que en ese entonces no entendía.

También me acuerdo del primer límite espacial, además de aquel mencionado en el que se manifestaba más materialmente, a través de esa cuerda amarrada a la cintura, este otro era el 
“alpechín” ${ }^{14}$, nos prescribían no acercarnos, era una norma generalizada pero no sé por qué tenía la sensación de que mis amigos, se me evocan más las figuras masculinas, utilizaban más ese espacio, ellos elegían más esa zona para esconderse cuando jugábamos al escondite, yo optaba por otras, ahora pienso que era un pequeño miedo que se me iba metiendo en el cuerpo pero que chocaba con el uso que ellos hacían de él, sensaciones que hasta ahora no había sabido ponerle nombre, y es que ellos desde pequeños, son alentados a arriesgar más.

Las normas fueron llegando con la edad, las prohibiciones, las separaciones. Un momento crucial respecto a esto fue la comunión, antes de hacerla mi madre me envió un mensaje desolador, a partir de este hecho ya no podría estar en verano sin camiseta, como los niños estaban, no porque yo quisiera hacer lo que ellos hacían sino porque eso era cómodo y no entendía bien la restricción, pero se me iba explicando a través de la norma, y ya no me estaría permitido pasar tanto tiempo en la calle: comenzaba el proceso de domesticación. La frase de mi madre era algo así como -después de que hagas la comunión las niñas pasan más tiempo en sus casas- frase que me hacía presentir un intento de reclutamiento, no hablaba de mí sola, sino del conjunto del nosotras. Sería fallido en mi caso, no entendía el porqué.

Con los años se perdió el control de aquel espacio que correspondía a la infancia, las calles que han quedado relegadas a la cultura impositiva y a la vez socialmente admitida del coche, ya no se escuchan sus gritos, sus risas, sus ajetreos, sino motores rugientes, los dueños de la calle.

Paseando por las calles de Marruecos se muestra una foto tan remota como familiar, Ixs niñxs jugando en la calle me recuerdan a mi infancia, en ese abandono al afuera, ese lugar en el que se explora, se curte, se aprenden los trucos de la interacción, donde la calle se representa

\footnotetext{
${ }^{14}$ Líquido viscoso, oscuro y maloliente que se produce en la almazara tras presionar la pasta de aceituna, antiguamente era arrojado a un espacio enfrente de ésta y formaba una especia de lago con el que se representaba una especia de arenas movedizas, la cual constituía un peligro tremendamente alto, quien allí se caía, se decía era muy difícil pudiera salir.
} 
como una pizarra de escuela, en la que niñas y niños aun comparten el mismo espacio, más tarde vendrá también la separación. Me costaba ver a chicas adolescentes en la calle, imagino que usaban el espacio diferentemente y que aun en esa hiperregularización también encuentran sus grietas.

Aquellas vivencias de calle continua, de tiempo interminable en el "afuera" se fueron relegando a este otro modelo de hiperprotección que me iba encorsetando, la protección estuvo siempre, pero al principio no habría tantas cosas de qué protegerse, acorde a los ojos de mis progenitores, percibo que dicho corsé fue impuesto a la par de mi desarrollo sexual, entiendo que aquí había que proteger otros menesteres, quizá mi cuerpo, mi sexualidad y lo que ello conllevaba en ese contexto en el que yo nací, aún cualquier hecho que de ello se derivase afectaría no sólo a mi cuerpo sino a toda mi familia. Mi primera hazaña reprimida al respecto fue cuando aún tenía unos seis o siete años, la experiencia del pajar. Habíamos estado un grupo de niñas y niños en el pajar de uno de ellos, de pie, en círculo y con nuestras bragas y calzoncillos bajados, uno de ellos pasaba y nos ponía inyecciones en el culo con una panocha (la base de la mazorca del maíz, sin granos), cuando salimos de allí y le pedí a mi hermano que lo encontré jugando por otro lado que me ayudase a subirme la cremallera de mi mono, él aun sin saber nada, lo intuyó y fue corriendo a decirle a mi madre, él era el vigilante y ella quien me propinaría el castigo. A partir de ahí sentí el miedo a verme en una situación como ésa, ya sabía que jugar con los niños a "eso" estaba totalmente censurado, aunque con las niñas encontraba una fisura.

Recuerdo, más adelante, las restricciones de movimientos y tiempos, en mi caso no me ajustaba a los mismos parámetros que mis amigas, pues a mí no me permitían entrar en la discoteca (el portero consideraba que no era lo suficiente mayor puesto que mis rasgos sexuales no eran prominentes en comparación con mis amigas) y mi toque de diana era muy estricto, ya no recuerdo en base a qué se justificaba, más bien porque sabía que no era una 
justificación congruente, sino que detrás era un intento de mantener la relación de poder, mi padre era quien me imponía y mi madre quien me concedía exenciones, en ese juego de poderes y resistencias aprendía a moverme, pero siempre desde la superprotección y la vigilancia. Mis palabras debían dar cuenta de los lugares frecuentados, palabras que podrían ser contrariadas por otras palabras de agentes externos (vecinas o vecinos), casi todo se sabía en el pueblo y con estas fuerzas habíamos de manejarnos, encontrando huecos de intimidad, nuestros, donde pudiésemos ser más nosotrxs, esos espacios revertidos en significado con respecto al mundo adulto, la noche aun con sus sombras no estaba contagiada de temores sino su opuesto, un espacio de intimidad, protegido de la mirada observadora del poder, en este caso "el qué dirán". Hablo en plural pero no recuerdo que hablásemos sobre estos temas, probablemente fuese una percepción compartida, aceptada, de la que no había nada que hablar, estaba naturalizada. El control procedía no sólo de nuestras familias sino del pueblo, cualesquiera ojos podían estar observando, capturando sólo un momento, descontextualizado y eso me hacía estar atenta a que no hubiese disonancias, que nada se hablase de mí, de lo contrario me destinaba al castigo, castigo que incrementaría más aún el control. Recuerdo que regresaba a casa musculando los gemelos, acelerada, con el miedo no sólo en mi mente, también se extendía a mi cuerpo físico, llegaba tarde. Me parecían tan injustas estas situaciones que no me quedaba otra posibilidad que aceptar que yo vivía en un mundo injusto, que era así y no lograría más libertad hasta que no fuese mayor o hasta que tuviese una pareja, hecho que en mi contexto hacía equiparar a la mayoría de edad, aunque no era algo en lo que yo pensase como solución a estos logros. Por supuesto yo encontraba mis grietas en esos muros que me contenían y aprendí a desarrollar estrategias varias, una de las más eficaces la técnica del eludir información, asumiendo riesgos con sus consecuencias paralelas.

Intuía que detrás de este empeño de resguardo se guardaba algo más, se me hablaba de sexualidad sin nombrarla, también de ámbitos, los movimientos espacializados que me 
correspondían siendo una chica. Esto me lleva a pensar en Foucault, en su Historia de la Sexualidad, cuando en la época victoriana hay una impresión de que el sexo no se habla pero basta echar una mirada a los dispositivos arquitectónicos y a la organización interior para ver que está siempre presente. Los poseedores de autoridad mantienen una estricta atención a las precauciones, las disposiciones, los juegos de castigos y responsabilidades, los espacios de la clase, la forma de las mesas, los patios de recreo, la distribución de los dormitorios, la vigilancia a la hora de dormir (en centros internos). Todo esto remite a la sexualidad de niñas y niños y con ello se dice que la sexualidad existe, es precoz, activa y permanente. Desde aquí hay una incitación, se activan los discursos en torno a la sexualidad pero desde el poder, con la intención de regularización. "Lo propio de las sociedades modernas no es que hayan obligado al sexo a permanecer en la sombra, sino que ellas se hayan volcado a hablar del sexo siempre, haciéndolo valer, poniéndolo de relieve como el secreto" (Foucault,1991: 47)

\subsection{Ampliando los recorridos, experiencias negadas: los enfrentamientos.}

Llegó el momento del enfrentamiento, mi mente necesitaba ampliar recorridos y pese a la negativa de mi madre de viajar al País Vasco, a eso de los 16 años, donde tenía una buena amiga y amigo, descubrí que las consecuencias no serían tan severas, aunque cierto temor se albergaba en mis adentros había una fuerza interna también que me obligaba a arriesgar, ya no me afectaban tanto como cuando era niña, supe que los límites también se franquean. Y esto se convirtió en un interés perpetuo, no el transgredir sino el movimiento, lo que mis ojos veían ahí fuera contagiaron a mi cuerpo por el deseo de descubrir, de vivir todo esas otras experiencias que me eran negadas en el ambiente del pueblo. La primera vez que me subía en un tren, fuera del recorrido conocido, Leioa-Bilbao-Zumárraga, un pueblo de Guipúzcoa, donde mis amigos vivían, me provocó una amalgama de sensaciones contrarias, miedo y excitación, 
regocije de paisajes con nudos en el estómago y la culpabilidad del desafío. Dado que la experiencia resultó más que satisfactoria ya no había quien me parase, estaba dispuesta a resarcirme de todas esas normas morales de la sumisión y el acatamiento para descubrir algo nuevo por mí misma, descubrirme a mí sola, yo con mis recursos personales en construcción.

Esta vivencia fue absorbida por los poros de mi piel, los que se hicieron adictos, dando lugar así a un periodo de experiencias varias constituidas por mí, sola, en lugares desconocidos, lienzos blancos esperando ser significados aun sin mi decisión, cada encuentro con alguien en un lugar, colores nunca vistos (no podía imaginar los innumerables tonos verdosos que existen, el sur entiende más de marrones), el sonido de unas campanas, los pájaros como programados empezando a cantar a la misma hora, las sensaciones despertadas por el cántico de unos rezos, el cuerpo lleno de dragones (lagartija típica de las Baleares), los sabores inusitados, los temores que albergan cada lugar con la excitación de lo inimaginable, el olor de la humedad de la madera de un barco abandonado, el dormir en otro que se mece sobre agua, una tormenta eléctrica contemplada desde su escotilla, yo sola en la oscuridad de la noche, bajo una sabina, aprendiendo a lidiar con las sombras, con los recorridos solitarios por caminos a la luz de una dinamo, con olores a tierra mojada y lavanda, todas ellas constituirían sensaciones sinestésicas múltiples que configurarían la historia de cada lugar y mis deseos de franquear mis mugas, aquellas que aunque parezcan lejanas aun me acompañan en el cuerpo. Nuestras subjetividades decoran esos lienzos que terminan siendo pintados, pero con una pintura que se difumina, se diluye, se intensifica e incluso que cambia de color. Así cada persona dibujamos nuestro espacio, distinto tanto como diversxs somos, pero aún dentro de toda esta diferencia se pueden encontrar muchas similitudes, puesto que lo que nos llega a través de la mirada está ahí, repitiéndose, y ya deja de ser extraño y los colores acotados. El lugar está ahí fuera, esperando ser pintado con unos ojos distintos, con colores llamativos, pero un tiempo después las pinturas tienden a igualarse, los colores a difuminarse, aún con nuestra capacidad creativa 
el espacio se resiente y empezamos a observarlo quieto, resistente, con sus formas fijas, con sus calles duras, las esquinas afiladas, los parques domesticados y las farolas que siempre proporcionan las mismas siluetas.

\subsection{Ensanchando el espacio: el encuentro con la diversidad cultural y el acecho del miedo.}

En mis deseos de conocer lugares nuevos, de observar lo inimaginable, en aquellos días en que el internet era sólo un proyecto futuro, no sólo me impulsó mi infancia sino que el encuentro con la Antropología me proveyó de alas invisibles y también de lentes para mirar a los fenómenos acontecidos cuando cultura y espacio se encuentran, interactúan.

Tras este aporte de la Antropología mi forma de moverme en los espacios cambió, se hizo más consciente, más reflexiva. Cursando la asignatura de Antropología del Género, impartida por Carmen Gregorio, quien me hizo pensar en ideas hasta ahora sin cabida en mi mente, a través de su específica metodología, guiada pero no impuesta, sin jerarquías, promoviendo el debate y el resurgir de ideas propias, individuales, enseñando a cuestionar, hubimos de realizar un acercamiento al trabajo de campo, a la observación y en grupos anduvimos observando los espacios que nos habíamos asignado para trabajar sobre ellos, basado en un libro de Teresa del Valle, Andamios para una nueva ciudad. Este trabajo me aportó una nueva mirada en este campo, en cuanto a cómo se conforman los espacios, sus usos, límites y jerarquías, la espacialización genérica, entre muchas otras cuestiones que jamás me había planteado. Desde este justo momento mi transitar por los lugares comportaba pensamientos nuevos, más cuestionadores, más analíticos.

En mi tránsito por distintos países presto atención a la organización del espacio, siempre atraída por las "periferias", no sólo localizadas en los márgenes, también en los centros y 
barrios en los que se escurre lo normativizado, aquellos lugares que dan lugar a construir algo distinto a lo estipulado por quienes ejercieron el poder de definirlos, de construirlos. Se puede planificar la ciudad pero no lo urbano como reporta Manuel Delgado, aunque se intente hacer lo contrario. En Inglaterra okupé con otras persona algunos espacios, con la intención de crear un lugar distinto, en consonancia con las relaciones que quería construir, más igualitarias, sin jerarquías, asamblearia, otra forma de conceptualizar la casa, un proyecto poco exitoso. La mayor parte del tiempo éstas se encontraban localizadas en el barrio jamaicano, St. Pauls, lo que constituyó el guetto y derivó en uno de los espacios más heterogéneos, donde más población con culturas distintas reúne, con una minoría blanca. Este barrio me provocaba perplejidad ante las diferencias, me chocaba rotundamente el encuentro de la cultura jamaicana, con su relación hacia el exterior, sus formas de moverse, de caminar, de ocupar la calle, con sus ropas que dejaban gran parte del cuerpo al descubierto y su apariencia extrovertida y "peligrosa" junto a la somalí, (dos de las mayoritarias en este barrio), con su relación más hacia el interior, también con sus formas de moverse, de usar el espacio público, sus atuendos, sobre todo los de las mujeres, que ocultaban todo el cuerpo, cubiertas hasta los tobillos pero que a la vez me volvía a sorprender el sonido de sus pies al caminar, vestían zapatos de tacón, a pesar de que el Corán advierte que no es positivo hacer ruido al caminar, el anonimato en la calle. A la vez que ellas cubrían sus cabezas y no era posible ni reconocer el color de sus cabellos muchas veces teñidos, al que sólo podían alcanzar a contemplar sus maridos e hijxs y otras mujeres del entorno cercano, las jamaicanas disponían de una amplia gama de pelucas, dispuestas en sus habitaciones para cada día concreto. Culturas dispares para mí, a simple vista que comparten un mismo entorno, moldeado, nuevo, en el que ninguna de ellas es la misma que sería en su lugar de origen.

Éste era el barrio catalogado como "peligroso" y en mi caso atraída por estos lugares, a sabiendas que son los que más carácter comportan además de tener la intuición que por algo 
se caracterizan así, no es "neutro" este calificativo ni su intencionalidad. A mí siempre me atrajeron las lindes, los bordes, lugares que se contagian de lo uno y lo otro, de lo que intentan separar, por ser lugares donde las normas se resbalan, se esgrimen tras sus lindes, lugares que emergen ahí donde no se esperaba, resignificados, pienso por ejemplo en ese descampado que haría temer a mucha gente o ese parque que se convierte en una frontera nocturna para los pies de muchas personas, sobre todo mujeres y personas mayores, y cómo revierte su significado cuando es ocupado por jóvenes que encuentran en este emplazamiento su propio espacio, aquel que tiene connotaciones totalmente dispares a otras personas, aquel que yo y mis iguales buscábamos fuera del mundo regulado de los ojos adultos.

Esa etiqueta de "peligroso" siempre me atrajo, la percepción de este peligro relativo ha ocupado mi elección preferente en todos los sitios que he vivido o a la vez todos los sitios en los que he vivido han estado cargados de ese matiz, que no significa sea una mera característica, todas esas advertencias repetidas configuraban mi imaginario y no sólo el mío, lo cual me hacían pensar en situaciones sucedidas, instrospectarlas, y en definitiva hacerlas mías y compartirlas, el contagio de las advertencias. También en mi vivía la actitud crítica de "eso" que se decía, aún sin saber el porqué, necesitaba contrariarlo, abrir una ventana para la duda, intuía que no era tan verdad lo que se decía o más bien que las consecuencias de lo que se decía no eran las que serían más favorables a mi forma de ser, a la rotura de mis cadenas, de alguna forma presentía que estas advertencias robustecían aun más mis grilletes internos.

No ha habido viaje que no haya estado acompañado de advertencias, por la gente de este o aquel lugar, las guías turísticas, la voz de los aviones que más que advertir amenazan, cuando vas a hacer un trasbordo en lugares icono de esta cultura mediática del miedo, como Estados Unidos, en la que se hace mucho hincapié en todos las instancias a rellenar antes de pasar la aduana, el paso de uno en uno (individualización del miedo), excepto las parejas heterosexuales que sí pueden pasar conjuntamente (un miedo compartido que da menos 
miedo), a este respecto nos ocurrió algo gracioso en Miami, de camino a México, viajábamos mi amiga y yo, la pareja antes de nosotras pasaron el control conjuntamente y cuando nos llegó la hora a nosotras, nos llamaron la atención -de una en una-, a lo que nosotras nos negamos, cuestionando al policía el que si las parejas pasaban juntas nosotras entonces queríamos pasar juntas porque también éramos pareja, y ante su bloqueo nos dijo que teníamos que vivir juntas, esperando que este hecho fuese un improbable, pero nosotras vivíamos juntas, así terminamos esta experiencia de control de aduanas, entre risas y cuestionamiento. Estas advertencias acerca del "peligro" nos las ofrece mucha gente, incluso sin preguntar, sostenido con este carácter de cuidado o preocupación. Advertencias que en la mayoría de los casos dicen más de quien está hablando que de lo que está hablando, de ese poder encarnado en los cuerpos, que no necesita imposición ninguna, ya vive dentro con esa mirada regulada, como ese panóptico de Foucault, en el que estamos siendo observados sin ver a quienes nos observan, no necesitamos más un ejercicio de vigilancia externa, hemos autorregulado nuestras conductas con un estado de consciencia y siempre al descubierto, asegurando el funcionamiento automático del poder.

Recién llegada a Bristol (Inglaterra), un lugar que sólo me amparaba a nivel físico, no me daba cobijo a ningún otro nivel, ni emocional, ni mental, ni económico, ni a mis deseos, un lugar en el que no sabía interpretar los símbolos, no hablaba la lengua con lo cual, la clave más eficiente en mi interactuar con el lugar se basaba en lo no verbal, en las agudizadas observaciones, en las sensaciones despertadas, lo intuitivo. Ese no entender me llevaba a acercarme en exceso a las personas, no entendía sus palabras pero leía sus cuerpos, intentaba también leer sus ojos, distancia ésta que resultaba incómoda a mucha gente, lo que me recordó a Flora Davis con su Comunicación No Verbal y su análisis acerca de la construcción cultural de las distancias. Cualquier persona inglesa que viaje a Marruecos sin ser advertida al respecto puede sentir violada su intimidad, su espacio. A este respecto, me sentía más cercana culturalmente a gente 
de origen magrebí que británica, la forma de relacionarnos en y con el espacio, los saludos, los decibelios de la voz, la receptividad para dar pie a una conversación, a un acercamiento, hacía que nos definiésemos como mediterráneos en relación a estxs "otrxs", personas británicas, con todas las características que estaban implícitas en esta diferenciación.

En mi búsqueda de trabajo caminaba por este barrio, como una extensión de mis bordes que me iba marcando cada día a través de mi mapa conocido, sola, a las cinco de la tarde de un noviembre, de noche. Al llegar a casa y comentar dónde había estado me advirtieron "ése es el barrio chungo, el barrio jamaicano, el gueto”. Lo único que a mí me invadió fue la extrañeza, nunca había visto tanta gente jamaicana, tampoco sabía antes de la advertencia del origen, lo único que identifiqué a primera vista fue el color de sus pieles y entonces pensé que me estaba acercando a esto de la archiconocida multiculturalidad británica, de la que yo no conocía nada, nada acerca de sus orígenes ni rasgos distintivos de sus culturas pero sí que estaban vestidas de peligro, de amenaza (representada en los medios de comunicación), de diferencia. Durante cuatro años fueron tantas las anotaciones y avisos acerca de la aprensión de vivir, relacionarme o transitar sus calles que no necesité redefinir nada porque cuando comencé a darle significado al barrio, yo, ya era parte de él. Tuve la fortuna de venirme a vivir a él antes de escuchar demasiados consejos preventores, gracias también al poco nivel de inglés que manejaba en ese entonces, la información no llegaba del todo, lo que me hacía sentir vulnerable, pero tampoco esta otra información llegaba, la cual habría aumentado esta acaparadora sensación. Este discurso sobre la peligrosidad de St. Pauls resonaba incluso en la periferia, en los barrios "marginales", en esos otros barrios catalogados como peligrosos también para la ciudadanía del centro, pero que como estaban más alejados era sólo un peligro lejano, nada habrían de hacer estas personas en este barrio, no estaba de paso, como sí lo estaba el otro, el jamaicano, al lado del centro, así en las conversaciones estos barrios periféricos, Hartcliffe y Wittiwood no aparecían, sólo a modo de nombre volátil y acompañado 
de sonidos fantasmagóricos, pero nombres que no afectaban a la gente por no estar en contacto, con lo cual el peso de la sospecha inmediata recaía en St. Pauls, el lugar de la mixofobia.

Trabajaba en un autobús itinerante, íbamos a estos otros barrios "deprivados" que no existen en el imaginario de muchas personas, más que de oídas y a modo de mitos, a éste accedían jóvenes del barrio, el autobús era un punto de encuentro, con internet (que no funcionaba la mayoría de las veces), una pequeña biblioteca y un punto de información sobre uso y abuso de sustancias y educación sexual y para las relaciones, con la intención de ofrecer un espacio en el que la gente joven intercambiase con otrxs jóvenes y adultxs que trabajábamos en esto de la educación informal, tratando de retarles sus pensamientos (homófobos, sexistas, racistas, violentos, etc), darles herramientas para su empoderamiento. También allí, cuando me preguntaban sobre mis andanzas, abrían sus ojos con incredulidad, algunas de las respuestas eran "pero si aquello está todo lleno de armas y drogas, de violencia". Me resultaba paradójico que aquellos que conformaban una comunidad socialmente excluida proyectasen el peligro en otro sitio, también habían asumido el discurso de la peligrosidad, en el que ellos estaban insertos, pero había otros aun más peligrosos, de quienes no sabían nada excepto el lugar de procedencia, su color de piel y la asociación de esta comunidad con el crimen, imagen que los medios difunden atendiéndose a la realidad que habita en sus propios sesgos. Cada grupo construye su imagen del miedo, un miedo que siempre viene de otro sitio. El mal siempre viene de fuera.

Como punto de identificación en mi experiencia sobre la diferencia cultural me percaté que la diferencia no es una simple distinción, sino que está jerarquizada y que el miedo también jerarquiza. Se juzgaban los lugares en función de quienes vivían en ellos, con todos sus elementos socio-económicos incorporados: Cliffton, un barrio homogéneamente blanco versus St. Pauls, donde la mayoría son de origen jamaicano y somalí, incluyendo otras minorías, un 
lugar de gente de fuera, que por ubicarse en una zona anexa al centro, con mucho suelo que liberar, está viviendo un movimiento gentrificador que está trasladando a muchas personas a otra zona un poco más alejada, el siguiente barrio, más residual, el barrio de Ixs inmigrantes, también el más heterogéneo, el que engloba el mayor número de personas con orígenes variados y remotos, sus calles están plagadas de multiculturalidad, y dentro de este mismo barrio las diferencias también son palpables y la comunidad está cohesionada frágilmente, hay grupos diferenciados atendiendo a su origen pero que viven muy cerca. Forman un grupo homogéneo a los ojos de la gente de los barrios "ingleses" (todxs son inmigrantes) pero uno bien diverso y diferencial atendiendo a quienes habitan este barrio. Hay un gran empeño en la demarcación de límites en el que se pretende hacer visible quienes pertenecen a la ciudad y quienes no, "no hay identidad sin la presencia de los otros. No hay identidad sin alteridad" (Augé, La Nación). "Es estúpida la idea de que la multiplicación de los contactos con el exterior es una amenaza contra la identidad, algo que se escucha a menudo. Creer esto presupone que hay una identidad desde siempre constituida así, y nunca fue el caso". (La Nacion). Cada vez más personas viven en lo que Edward Said (1979:18) ha denominado una condición generalizada de orfandad, un estado en el que las identidades están siendo a su vez, más desterritorializadas. Las prácticas culturales no son "puras" ${ }^{15}$ sino que se mezclan y funden con otras procedentes de otras culturas, a la par las identidades, que ya no son estáticas como creíamos sino que se van reajustando en distintos lugares, generando otras nuevas. Las mugas divisorias entre el "aquí" y el "allí", el centro y la periferia se están difuminando. La movilidad que no es sólo física sino también social y cultural, no pertenece sólo a las personas que van de un lugar a otro, sino también a quienes se quedan, el intercambio conforma una cultura nueva que no es la de un lugar ni la del otro, sino otra emergente. La creencia de que un país lleva aparejada su cultura, como un ente esencial ya ha cambiado, no hay lugares

\footnotetext{
${ }^{15}$ Esta idea de pureza procede de Mary Douglas, desde una perspectiva simbólica en la que se entiende como una justificación contra las "invasiones" culturales, prendiendo la maquinaria para paralizar dicho efecto, maquinaria que funciona a base de miedo, lo que provoca una exclusión de lo diferente (o mixofobia).
} 
inmaculados, "puros", donde cultura y lugar están íntimamente conectados, coinciden en un sitio, sino que estamos conectados por flujos, movibles, mutables. "Lo inglés" por ejemplo, es una idea desterritorializada, es una idea imaginada más que un lugar fijo en el mapa.

Considero que se llevan a cabo políticas dicotómicas, asimilacionistas, por un lado un interés en el bienestar general, en eso acerca de la inclusión pero desde una forma limitada, regulada y ordenada desde el prisma del grupo mayoritario, hegemónico, lo que a su vez excluye lo diferente, lo que es mas diferente de lo que se tolera. Así, se lleva a cabo una espacialización de las diferencias de clase, el centro le corresponde a esos grupos mayoritarios y de clase social privilegiada, quienes imponen sus parámetros de civilidad inscritos en la compilación de normas de urbanidad, mientras que quienes se escapen de ellas, se escurrirán y se deslizarán a los márgenes (García. Jujuy).

El poder es una de las pocas cosas de las que raramente se ve un mapa. Sin embargo, una geografía del poder (...) es la que sustenta mucho de lo que experimentamos en cualquier área local. Y es sobre las intersecciones de todas estas geografías que tal "lugar" adquiere tanto su unicidad como su interdependencia con cualquier otro sitio (Massey 1995: 71, traducción mía).

No sólo se espacializa la clase y la etnia, también el género. El lugar que más lo evidenciaba era St. Pauls, Easton, St. Werburghs, con una numerosa población asimilacionista. Suponen lugares de contraste, de mezcla, de incoherentes razonamientos, de realidades instaladas en los escaparates "étnicos", en los bares, restaurantes o shawarma atendían hombres, las mujeres se filtraban a través de una ranura en las cocinas, algunas veces o en las tiendas de textiles pakistaníes, pero aún aquí, que podría ser considerado parte del espacio doméstico, pues en muchas ocasiones la tienda se encontraba bajo la casa, no permanecían solas, ellas siempre estaban acompañadas, caminaban acompañadas, no acostumbraba a ver muchas mujeres con sus ropas tradicionales caminando solas. Ellas estaban en los mercados, en las 
tiendas donde se hacían tatuajes de henna y se practicaba la depilación con la técnica del hilo, en las clases gratuitas de inglés, pero después de sus trabajos y/o actividades su destino era la casa, lugar en el que la mayoría de ellas sienten como su espacio propio, también sus patios con sus huertas que ellas cultivaban, donde pasaban tiempo tendiendo la ropa, comunicándose, resolviendo conflictos familiares, riéndose y quemando sus basuras, práctica ésta que me impresionó, como lo era el hecho de que muchas mujeres no supieran inglés, no lo necesitaban para su cotidianeidad, no estaban expuestas a la vida pública, al menos no con la población mayoritaria, entre sus familiares y conocidas hablaban urdú, parecía que no sería necesario aprender la otra lengua, la del lugar de llegada, al menos para las mujeres de determinada edad, ellas no tendrían que irritarse en el solventar la desconectada burocracia. Presumiblemente, los hombres mayores que han llegado acompañando al resto de la familia, tampoco lo hacen, aunque yo no me encontré a ninguno, aunque mal articulada todos chapurreaban. No es sólo la lengua ese indicio que separa a gente dentro del mismo espacio, son tantos y tantos símbolos los que nos hacen denotar las diferencias espacializadas, las exclusiones, las legitimaciones.

En mis lunes noche trabajaba como voluntaria en una organización que daba apoyo a las trabajadoras de la industria del sexo en Bristol (Inglaterra). En una furgoneta ampliamente identificable y familiar para las mujeres que ejercían este trabajo y también para sus séquitos, aunque sólo ellas podían tener acceso, nos dirigíamos a esas zonas de calles anchas, calles sólo para coches, cualquier persona caminando por ahí era sospechosa, si alguien pasaba tenía que hacerlo a ritmo acelerado que fuese reconocible que iba de paso, otro no-lugar, en el que no está permitido pararse, en el que flota la sospecha, un lugar resbaladizo. Este lugar ha cambiado múltiples veces su localización, conforme alguna norma jurídica nueva al respecto se promulgaba, lo que abocaba a las mujeres a lugares más recónditos, más inaccesibles, inhóspitos, alejados de la mirada reguladora de quienes construyen la ciudad, allá, a los bordes 
de las calles cada vez más anchas, más duras, en los pasos subterráneos, descampados o zonas industriales desoladas, inertes, inspiradoras del miedo. Lo que no ha cambiado nada ha sido el contexto, inspirador de temor y sospecha. Ellas subían en la furgoneta donde se dispensaban condones, lubricantes, comida y bebida caliente, además de una conversación, un intento de construir relaciones de confianza, de conocernos, de charlar, de aportarnos experiencias, información, opciones, un lugar de denuncia, de lloro, un lugar libre para expresar y seguro. Me decían que tenían miedo, miedo a los clientes -no sabes con quién te metes en el coche, puede ser un descendiente de Jack "el destripador ${ }^{16 "-,}$ miedo a los acosos, miedo a la policía, miedo a las enfermedades, un miedo que vive dentro del cuerpo ya acostumbrado, como esos tacones esclavizadores en los que aprendes una postura para hacer equilibrio y poder sostenerte en ellos durante horas, como esos ropajes que mutaban la piel de color morada donde el invierno hacía su estampa, ya incluso ese color lo hicieron suyo. Color que comparten con muchas chicas jóvenes que nada tienen de semejantes, éstas otras no trabajan como prostitutas y no gozan de esas medidas exclusógenas, ellas están en el centro, marcadas por el mainstream, se exponen a otros controles, son distintos, pero también perversos, en ambos casos suelen proceder de figuras masculinas. A todas las violan, todas son violables ${ }^{17}$. El cuerpo de las mujeres como disponible, como una representación de consumo, mujeres que vistas en entornos públicos, pueden ser confundidas con prostitutas. "Así las mujeres "libres" se convierten inmediatamente en mujeres públicas, es decir, presas permitidas para los hombres” Pitch, 2008:285) Tras una matanza de mujeres en el Reino Unido, en los '70, la policía asumió

\footnotetext{
${ }^{16}$ La historia utilizó el miedo a Jack el destripador para mantener a las mujeres en casa a final del siglo XIX, es contada por Judy Walkowitz.

${ }^{17}$ La diferencia es que unas no denunciarían porque su credibilidad estaría cuestionada. Hasta no hace mucho en Inglaterra en un juicio por violación o acoso sexual dicha veracidad de la verdad estaba afectada por la clase, no sería creíble que una mujer de clase baja fuese violada por un hombre de clase media, mientras que sí lo era si la mujer era de clase media y el hombre de clase baja, también dependía de eso que llamaban "pureza", el ser virgen o no, el haber tenido relaciones sexuales con otros hombres de alguna forma era algo que te hacía más proclive a que te pasase, de la misma forma que se justificaría que el que te roben en casa está relacionado con haber tenido antes amigos invitados en ella. Así las trabajadoras sexuales, violadas en muchas ocasiones también se creyeron que esto lo merecen por estar donde están, por pertenecer a ese mundo "sucio" de la noche, el sexo y el espacio público
} 
que eran prostitutas, por encontrarse en el espacio público, donde se las construye espacialmente, solas. La identidad sexual de las mujeres se determina a través de su localización espacial y movimientos.

El uso no recomendable de vagar por estas zonificaciones del riesgo me hacía más deseosa de explorar, pues entendía que algo ocurría ahí que quienes ostentan poder quieren aniquilar de la existencia, de la memoria y a la vez me cuestionaba acerca de la construcción de la peligrosidad, en mis observaciones se llevaban a cabo en base a la inmigración, de la que yo también formaba parte, de alguna forma, aunque blanca y con un nivel académico impensable para la media inglesa, sentí como a mí también se me construía, claro, que todo este imaginario construido en torno a ser española iba acompañada de control, sobre todo en las tiendas, donde la persona de seguridad persigue a quien esa lengua habla, de estereotipos respecto al trabajo, a la siesta, la fiesta, pero también impregnada de exotismo. Entendí y experimenté lo que significa ser una inmigrante, sospechosa. Sobre todo cuando no hablas la lengua y vives en universos separados y es en este terreno donde te sientes esa otra, posicionada jerárquicamente en un estadío más bajo, en donde las palabras no son las que discriminan sino sus silencios, lo que no se dice pero se ve. Me hice una experta en comunicación no verbal, no sólo por lo que siempre me atrajeron estos temas acerca de la teatralidad de los cuerpos y su no capacidad de teatralizar, sino por las necesidades que me aclamaban un perfecto detallar de los movimientos en orden a entender lo que sus palabras no me decían. Claro q sus ínfimos gestos algunas veces mencionaban grandes vocablos, a la vez que sus reacciones, sus distancias, sus caras de incredulidad, de asco, de despotismo, decían menos, aunque de estas personas dijese más, hablaban de sus estereotipos, sus prejuicios, sus subjetividades, el mobiliario viejo y sucio de sus mentes ordenado por la rigurosidad de la normatividad. Todo esto cambia cuando llevas un tiempo, cuando te mueves de una forma distinta en el espacio, cuando has incorporado las pautas culturales, las formas de 
comunicarte, no demasiado cerca pero en el mismo escenario, compartiendo el guión, no siendo demasiado intensa pero con ímpetu.

Pienso que lo que subyace de este aislamiento impuesto, de esta segregación y exclusión es el mismo miedo a estar ahí, a ser uno de ellos, así mejor lejos e invisibles a la mirada cotidiana.

El poder contaminante de las cosas a las que Mary Douglas hacía referencia puede también estar incluido aquí, personas que por no haber nacido aquí o no compartir las mismas pautas culturales son vistas como extrañas, una intromisión en la sociedad, se construye desde aquí la imagen del peligro, lo impuro, el foco de contaminación.

Tan solo tres experiencias relacionadas con el miedo en el espacio público me acontecieron, las dos primeras en St. Pauls, un hombre que parecía ir en una dirección y al verme salir de una casa su dirección cambió, vino detrás de mí y dudé si regresar a la casa de la que salía o correr hacía la mía q estaba cerca, opté por la segunda opción y a la llegada de la calle principal a paso acelerado había gente y el hombre se esfumó. Era un hombre de unos cuarenta años, blanco. Creo que se interesó por el ordenador que cargaba. La segunda tuvo lugar a escasos metros, en el mismo barrio, un chico joven, también blanco, con el que me acababa de cruzar la mirada, aparecía minutos detrás corriendo en silencio, yo iba en bici y algo que me hizo mirar atrás y sentir ese trotar desbocado y silenciado sólo me provocó lo instintivo del correr, pedalear rápido, a pesar de que mi casa estaba a pocos metros no fui capaz de parar en ella, sino que corrí por el barrio y me paré en la puerta de mi antigua casa, donde nadie había, nada que me cobijase más que la sensación de familiaridad con ese lugar. En este caso creo que también le pudo motivar a dicho maratón el color resultón de mi bolso y el contenido imaginario que en él pudiese confluir. La tercera, sin embargo, presentí que buscaba otros fines, me persiguió con un coche, de camino a casa, en mi otro barrio, en una zona donde hay nada, una fábrica cerrada durante el día y espacios oscuros y abandonados de 
la presencia pública, uno de esos pocos días que no llevaba la bici. Me aterrorizó, mi estrategia fue llamar a mi compañero de casa que justo acabábamos de despedirnos y se dirigía a un bar cercano, hablar con él para hacerle partícipe de lo que me estaba pasando, él seguiría al teléfono hasta que llegase a casa, una vez en la calle con casas y con la voz de mi amigo me llené de rabia, este tipo me estaba intentando intimidando pero no pude parar hasta que llegué a casa, cambiando de calle, pensando en rutas a sabiendas de que él iba en coche. Este hombre planeaba algo distinto del atraco, pensé en asalto sexual, sentí mi cuerpo peligraba, me dio miedo la perversidad de su mirada, de sus actos, no tan simples como los anteriores. En los días siguientes me cuestioné el tema de la violación, desde los componentes que en ella se reúnen como el quienes, tanto víctimas como perpetradores, dónde se suelen cometer, etc., y el cómo gestionaría yo esa terrorífica situación. Me di cuenta que me atemorizaba la planificación, los dos primeros me parecieron fruto de la espontaneidad y aunque ésta puede asustar por lo impredecible, alguien que actúa en estas circunstancias no sabes cual puede ser la siguiente respuesta, siento que la otra, la acción planificada es más malévola, está introspectada, lo que ha requerido de reflexión, tiempo y estrategias. En los tres coincidió, además de ser hombres, el uso de la mirada, no encontraron en mi forma de mirar competencia alguna, fortaleza o hacerles dudar, imagino me percibieron presa fácil acorde a su imaginario en estos temas, las mujeres construidas como seres débiles, fáciles de manipular y agredir.

Cuando regreso de Bristol para comenzar el máster GEMMA en Granada, me encuentro con un miedo que no conocía, o que ya había olvidado, se me hizo nuevo, tras cuatro años fuera en los que era excepcional el día que no regresaba a casa con bicicleta, me vi en mi barrio, el borde del Albayzín con Haza Grande, el sentirlo intransitable, no había camino exento de riesgo a esta nueva forma de vivir mis noches, donde la bicicleta no llegaba, había de hacerlo a la velocidad de mis pies errantes. De repente la noche se llenaba de fantasmas, me invadieron las historias acerca de los sucesos del Albayzín, los distintos robos, cometidos incluso a 
amigas, la supuesta violación ocurrida en una de las puertas de acceso a la urbanización donde vivo, que no sé si era real o no, pero ese pensamiento ya se había instalado de manera poco liberadora, robos, atracos, agresiones... todas ellas colocan una trampa a mis pies, que se vuelven endebles, enfermizos al empedrado albayzinero. Me recuerdo dubitando en una situación incluso acompañado por mi amiga, un miedo compartido que así se amplificaba: subir por los callejones o regresar en autobús, no fue el cansancio lo que nos llevó a tomar una decisión sino el miedo, contagiado por múltiples sucesos. Ese año pensé mucho en él, en las limitaciones que me ocasionaba, en que ya no sería capaz de regresar a casa sola caminando la noche oscura. Fue un encuentro con mi lugar, en ese mismo barrio donde residía antes de irme fuera, pero con ojos astigmáticos, veía cosas que antes estaban cegadas, no estaban. Fueron pensares y sentires acelerados en los que no tuve tiempo de hacerme de un racimo de opciones, volvía a casa casi como práctica obligada por el hecho de no sentirme coartada en mis pasos, pero el temor también venía conmigo. Miedo que exterioricé y mis amigas fueron partícipes, les pedía que me acompañasen. Ahora miro atrás y pienso qué fortaleza tenían ellas que yo no tenía y cómo veía lo que tenía enfrente que antes no veía. Me cuestionaba qué había cambiado, porqué me había invadido el miedo. Aún no lo sé, creo que la mezcolanza de todas esas historias que rondaban mis oídos, el factor afectivo en estas personas que te hablaban del miedo y quizá el observar mi espacio, el afuera de mi casa, el acceso a ella, en términos de urbanismo y planificación y sus carencias, como la insuficiente luz, descampados en los que el calor que en ellos se exhalaba procedía de los coches aparcados, ningún respiro, ninguna presencia perceptible, una zona desolada, un lugar que no invita a su paso.

Estos miedos que parecieron ocupar parte de las decisiones en mi cotidianeidad, que afectaban a mis itinerarios planeados en los que incluía el regreso a casa y en los que incorporé un nuevo elemento antes inexistente como es el taxi, se diluyeron al encuentro con otro lugar, otro nuevo lugar: México. Allá iría para una estancia breve de un par de meses como 
parte del programa de estudios (Acción 3), allá el miedo se volvió grande, intangible, amplificado, ya no estaba solo en el regreso a casa aunque también aquí. Los comienzos me parecen tan vivificadores, excitantes, un lugar en el que te encuentras con todo lo extraño también con sus fantasmas. Estos comienzos están repletos de exhortaciones y consejos. Cuando buscas casa con lo primero que te topas es con los lugares prohibidos, con las líneas francas, los trazos vedados, geometrías parceladas, los itinerarios permisibles y los circuitos amurallados, murallas invisibles que la gente bien reconoce aunque no están inscritas en ningún registro ni dibujadas en ningún mapa.

El primer lugar prohibido que me publicitaron fue el mercado (tianguis) de Tepito y La Lagunilla. Fueron muy numerosas las voces que auguraban amenaza. El miedo se me iba metiendo dentro pero también la curiosidad. Nos aconsejaron ir mal vestidas y sin ningún signo notorio de posesiones, lo que no era necesario ya que nosotras no tenemos un aspecto que hayamos de disfrazar a este respecto. En menos de una semana estaba con mi amiga en el metro dirección mercado. Ambos tianguis, por su extensión y cercanía llegan a conformar un solo mercado, ya no se sabe donde termina uno y donde empieza el otro, a priori, no por la disposición de sus puestos, pero las gentes de allí los distinguen. Todo estaba repleto de cosas, colores, gentes y ruidos. Las cosas no eran las que encuentras en otros mercados, sus productos eran más inusuales. El primero se distinguía más por productos relacionado con las "antigüedades", lo que incluía artefactos que no podías interpretar su funcionalidad, tornillos, mochilas, pendientes, artículos de decoración, de cocina, expandidos por mantas en el suelo, de todo lo más inimaginable, me recordaba al mercado de la Alameda de Sevilla, hace ya años, el otro mercado el de La Lagunilla, no me recordaba a nada, nunca visité un lugar parecido a ése, una representación de drogas, sexo y armas, estereotipos mexicanos. Tan sólo adentrándonos ya nos ofrecieron sustancias, mota (marihuana), a la vez que íbamos divisando una mesa que no tenía fin donde se mostraban artículos sexuales, películas, dildos, muñecas 
hinchables y otros juguetes, con sus particulares vendedores que también nos ofrecieron alguna sustancia relacionada con la erección y los juegos sexuales. Tras esta zona aparecía la de minerales y piedras semipreciosas y en una esquina donde no se sabía que acontecería aparecían piezas de animales salvajes, pieles, cuernos, que se usan no sólo como ornamento sino como útiles para limpias y actividades mágicas. Cuando ya creí que mis ojos se habían acostumbrado a aquel contraste, apareció ante mis ojos un puesto de armas, no parecía que fuese necesario tener permisos especiales para adquirir una. Ambos mercados compartían artículos comunes como la venta de películas, música y muchos productos textiles y electrónicos falsificados, además de comida y jugos. Lo que más me sorprendió fue todo eso ahí dispuesto, todo junto pero separado, conviviendo, en un ambiente tan caótico pero lleno de interacción, sin aparentes normas a los ojos de las personas que visitan pero con ellas para que estos nodos tengan lugar. Economía sumergida, pobreza, desigualdad, ímpetu de supervivencia, era lo que brotaba en aquellos lugares. Entendí que eso es a lo que se tiene miedo, lo que se rechaza, lo que no se quiere ver, como si el mero hecho de no verlo hiciese creernos que no existe. Pero allí también hay miedo. Percibí que eran grandes devotos de la Santa Muerte, un culto marginal y contestatario que procura la búsqueda del sentido a la vida en una ciudad caótica como México. Apropiada por quienes permanecen al margen de la ley: narcos, contrabandistas, sicarios y ahora también jóvenes y niñxs, madres solas y personas mayores. Otro artículo más de consumo para curar el miedo. La iglesia implementa santuarios que operan como espacios de poder y control frente a una realidad indomable, con el propósito último de construir la ilusión del orden.

También encontré otras figuras importantes en la cultura mexicana, como La Llorona, dando un paseo en trajinera (barca) por Xochimilco, el lugar que aún conserva el México originario, la única conexión con su pasado, cuando esa ciudad, con más de 20 millones de habitantes, era un lago. Hecho que a día de hoy me sigue asombrando, es un ejemplo del que todo se puede, 
a mis ojos un ejemplo de que cualquier cosa es posible. Dicen que la Llorona aun vaga por las chinampas (islotes fabricados en periodo mesoamericano) buscando a sus hijxs ahogadxs. Me contó el dueño de una de las trajineras que él mismo se encontró con un perro gigante, negro, muy extraño, en la oscuridad y que se llenó de terror, figura que él identificaba con La Llorona, fruto de su capacidad nagual, de transformarse en animal. Corrió y no quiso mirar porque si te cruzas por su camino te lleva con ella. Cada día de muertos se le hace una conmemoración y contaban que a veces ella se presenta a modo de espantosa tormenta que llega a volcar las barcas y a quien en ellas se concentra.

La primera vez que estuve en este país, en Chihuahua me encontré con otros miedos, los procedentes de un lugar inidentificable pero que se instauran en las casas, son los referentes a esos seres que viven en ellas, una especia de duendes o gnomos, pero traviesos o un tanto perversos. Me contaron que aparecían en la noche, cuando no podían ser vistos y alteraban el orden, desde cambiar las cosas de sitio o romperlas hasta arañar, arañaban las piernas. Esto de los arañazos era muy repetido. Le preguntaba a un profesor de la escuela de Antropología en Chihuahua si él también creía en estos seres, a lo que él me respondió: ¿me preguntas como persona o como antropólogo?- yo quise conocer las perspectivas encontradas, pero su respuesta fue tan solo una afirmación, -sí, creo en ellos, desde ambas miradas-. Me hablaron de animales mutados, sobre todo en la zona del desierto del Silencio ${ }^{18}$, reptiles e insectos con caras de bebé, me lo manifestaban con una mezcla de extrañamiento y miedo. En la Sierra, donde habitan las gentes rarámuris, en su cosmovisión los miedos son otros, procedentes de la naturaleza, miedo a las tempestades que aniquilan las cosechas, a los espíritus de los muertos

\footnotetext{
${ }^{18}$ Un lugar misterioso (sabiendo que lo misterioso sólo se mide en términos de ausencia de datos) donde aparentemente hay un campo electromagnético que atrae meteoritos y otros hechos insólitos, como la capacidad de inhabilitar y alterar radios y otros artefactos eléctricos, brújulas que pierden el norte, y donde me dijeron mis fuentes de confianza que la NASA está instalada y ésta no se instala en cualquier sitio, pero no pude hallar dato alguno al respecto. Se dice que por sus características ambientales guarda especificas curiosidades como fauna y flora inusual, endémica, como tortugas del desierto (evidencia de que alguna vez este lugar estuvo bajo el mar, además del hallazgo de fósiles marinos) y nopales (higuera) morados.
} 
y al arco iris, de donde vienen una especie de seres y se llevan a Ixs niñxs, formas que explican la mortalidad infantil. Hay también un pájaro que está impregnado de cualidades mágicas, se usa para determinados logros pero también es temido por sus poderes hechizantes, es un instrumento de control por parte de los shamanes. Los miedos varían dependiendo del contexto en el que se suceden.

Otro ser mítico junto a estos otros es el chupacabras, archiconocido en aquellas tierras. "La pregunta de fondo no es si el chupacabras existe realmente, sino señalar lo que esta figura desata en términos de imaginarios y de interlocución social" (Reguillo, 2006:70).

Todos esos seres que forman parte del imaginario colectivo de una sociedad no son sólo fábulas, en ellas se compilan los miedos y a través de ellos se puede esgrimir tanto la vulnerabilidad que azota a la sociedad como los mecanismos de vigilancia y control insertos (Reguillo, 1996).

Otros miedos en la ciudad estaban relacionados con prácticas satánicas en cementerios, sus autores están asociados con sectas y tienen una estética muy específica, vampírica, manipulan su cuerpo para provocar miedo (visten de negro, afilan sus dientes y se colocan lentillas azules o blancas), prácticas corporales relacionadas con el miedo; otros relacionados con bandas y sicarios, también tuve la oportunidad de toparme con uno que debió de fantasear conmigo y me confesó todos sus secretos, los que yo no quería escuchar, pensando que sus actividades me sucumbirían, le vería como un tipo duro, valiente, violento, como si éstas fuesen cualidades a dilucidar. Probablemente sí, en su forma de clasificar. Me mostró sus artefactos, como recortes de periódicos, guantes y pasamontañas. Incluso le acompañé a un lugar, a casa de una familia porque tenía que recoger $\operatorname{algo}^{19}$, éste fue el momento en el que me dio a conocer sus hazañas y caminar a su lado se convirtió en un acto atemorizante, comencé a imaginar la idea de que

\footnotetext{
${ }^{19}$ Algo acerca de una maleta, las conversaciones versaban en torno a armas, a advertencias, amenazas, un lenguaje no inserto en mis códigos.
} 
alguien saliera de un coche en mitad del asfalto, con los neumáticos rechinantes y de inmediato le bombardearan a tiros, imagen enraizada de las películas, no tenía otro referente de lo que ser un sicario significa, por supuesto esto lo viví en silencio, no le transmití mi temor, sabía que él ostentaría ese lugar en el que se estaba posicionando y desde allá me colocaría a mi también, con un carácter frágil yo sería la chica a proteger. Preferí engullirlo y no transitar el afuera con él en adelante, al menos no sola. Alguien que quiso posicionándose a sí en un lugar concreto, posicionarme a mí, a su vez, en otro.

Recuerdo que nunca caminaba sola de noche, o lo procuraba, cuando así era sentía que me deslizaba sobre arenas movedizas, que ése no era un lugar garante para mi ente como mujer, había escuchado tantas veces que no me alcanzase la noche sola, que no agarrase un taxi sin que identificase que fuese de los legales ${ }^{20}$, que lo interioricé, el miedo me despojó imaginaria y materialmente de la ciudad nocturna. La casa tampoco constituía un lugar seguro por estos seres que habitaban en ellas. Allí sentí que el miedo convive más de cerca, la ciudad está más impregnada de miedo, el afuera y el adentro y que la vida tiene menos valor y por ende se necesitan más fabricaciones subterfugias a esta realidad.

Cuando caminaba por las calles de Chihuahua con un hombre mexicano, un contacto de un profesor en España, y que llegamos a ser buenos amigos, un introductor a la cultura mexicana y sobre todo tarahumara, no me permitía caminar por la acera en el lado de fuera, ése era su lugar, yo tenía que ir en el interior de la acera, me lo hizo explícito cuando le cuestioné porqué siempre me cambiaba el lado. Sus discursos no son únicamente representación sino que también son acción y los mitos una confluencia entre creencia y acción.(Reguillo, 1996).

\footnotetext{
${ }^{20} \mathrm{El}$ término "legal" era algo mutante, lo que se decía que era requisito para que así se considerase ya no era suficiente unos días más tarde, a priori tenía que tener una " $A$ " fuera, al lado del número de taxi, después tenía que tener su foto donde dicho número pero dentro, lo sentía como un riesgo siempre ilimitado.
} 
Deambulando entre ciudades he percibido como el miedo se ha filtrado a través de las ventanas de las casas, aún con rejas, alarmas, instrumentos de seguridad y ante esto me he cuestionado qué precede a qué, que intereses podría haber ocultos, si es porque tenemos miedo que fabricamos este nuevo escenario, o a la misma vez todo este entramado está provocando una instauración del mismo, ¿cuál es la causa y cuál es el efecto?, lo que es incuestionable es que todos estos artefactos están construyendo una nueva realidad, la percepción del riesgo inminente interiorizandose en los cuerpos, el peligro que acecha al cruzar la puerta de las casas, aunque también tenemos que negociar con él dentro de éstas ${ }^{21}$, al doblar una esquina, al cruzar un parque, en un mercado aun con multitudes, mientras paramos en un semáforo, el miedo nos acompaña a cualquier sitio puesto que vive en nosotrxs. La cultura del miedo está tan encarnada que no existirán suficientes medidas para evitarlo, para hacerlo desaparecer. Con este entero entramado de seguridad, publicitamos el miedo, lo contagiamos y lo popularizamos.

Frente a todo este espacio de desajustes ajustados, de espacios abiertos, no sólo los mercados sino la extensión a sus barrios, con un fluir constante de gentes, de desconocidos, de incertidumbres, que van y vienen, rondan, cada persona ocupada de su propio negocio, de su propia necesidad, vendiendo lo que puede, el "pegamento cola-loca" compite en una esquina del zócalo con las banderas, símbolos aztecas, inciensos, comida, gorros, pistolas con golosinas con chile, cacahuetes fritos con chile y un largo etcétera en un inclasificable listado sistemático, en un lugar en el que parece que impera la ley de la selva, cada quien grita más, eso sí con exóticos acentos a los oídos extranjeros, con basuras, sin orden, con caóticos

\footnotetext{
${ }^{21}$ En un estudio llevado a cabo en la ciudad de la Plata (Argentina), Ramiro Segura identifica tres espacios en base a su trabajo de campo que constituyen las fronteras del miedo: el privado, la casa, lo familiar, lo íntimo; el público, el de afuera, anónimo; y el tercero, que ha sido identificado como el "área", el distrito, un medio entre los otros dos, un espacio transaccional entre ambos, donde conocemos otra gente y otra gente nos conoce. En su estudio ha mostrado cómo la gente se siente segura solo en su esfera privada, alguna en su área, pero todas están de acuerdo que el "afuera", la ciudad, está llena de peligro.
} 
devenires, su opuesto sería un lugar regulado, ordenado, con normas, con vigilancia y con grandes muros, un lugar seguro, un espejismo, un lugar imposible.

Aquellas expresiones de miedo tienen sus consecuencias en la alteración de espacios, a través de la presencia policial o grupos militarizados, el uso masivo de cámaras ${ }^{22}$, rejas y candados, alarmas, posesión de armas y urbanizaciones encerradas (gated cities). Todas ellas constituyen prácticas regulatorias del miedo, las cuales se han incrementado en los últimos años. Con el levantamiento de un muro estamos creando un espacio cerrado y la regulación de la mirada a través de dispositivos de vigilancia y control.

En las calles mexicanas se percibía un sentir de desprotección, de segregación, de diferenciación, de aislamiento, de contrastes, donde los muros y otros artefactos de seguridad han conquistado la calle, entendida antes de uso público. Estos no-lugares hipervigilados se muestran como la panacea a los males del miedo, la máxima protección como antídoto que invierte su importancia en detrimento de las personas. Quien gobierna las calles es el miedo, miedo a la muerte, miedo a la agresión, miedo al otro, miedo a perder lo que se tiene, miedo al miedo. En lugar de menguar los miedos con esta imposición de artilugios en el mobiliario urbano, en las formas de planificar, estamos haciendo una mención constante de su presencia, aún en lo que no se dice, se siente y en lugar de prevenir la violencia estamos creando ciudades más exclusivas y desiguales que profesan más inseguridad, más miedo. Así entre barrotes y autocontrol, manifestaría Carlos Victoria que se impone la idea de una vida sin riesgos, a lo que yo añadiría, riesgos que son bidimensionales, llenan tanto como pueden

\footnotetext{
${ }^{22}$ Cámaras que están ya interaccionando con nosotrxs. En Londres hay cámaras que hablan a las personas peatonas, si alguien tira algo al suelo la cámara te pedirá si por favor puedes recogerlo y lo hará con una dulce voz de niña, una voz que no puede ser confrontada, como podría ser la voz de un adulto. También en la universidad, hay un registro de los movimientos desordenados. Si alguien se mueve de una forma que no ha sido establecida como "normal", una persona, por ejemplo, moviéndose de una forma agitada o sentándose donde no es adecuado o se espera, las distintas cámaras se dirigirán hacia esa persona, advirtiendo a esa persona ( $\mathrm{y}$ al resto) que está siendo observada, lo que entiendo como una forma de domesticar los cuerpos.
} 
arrebatar, sin ellos nos quedamos sin uno pero sin lo otro también, aunque la sensación de riesgo, por más medidas que asumamos a este nivel, será imparable. El temor llega a ser un elemento que conlleva aislamiento y desaparición del sentimiento de comunidad, además de que también se ha encargado de instalar una cobardía asimilada, un "ver, oír y callar" entre paredes. Todas las personas tienen miedo al atraco, a ser asesinadas pero también a ser embargadas, a la pobreza, a incidir en los asuntos comunes de la vida pública y ese elemento manifiesta una crisis institucional y crisis de desconfianza en las demás, en la que cada persona debe salvarse a sí misma, como pueda, desplazando el vinculo democrático por una seguridad privada, sólo accesible a las élites. Aunque no sólo lo sienten éstas, el miedo también se democratiza, se populariza, será lo único que una e identifique a todos las gentes con sus distintos estatus, ni qué decir tiene que el dónde se personifica dependerá de dónde estas personas se posicionan.

Me marcho de México, un lugar que como describo lleno de miedos también está lleno de inenarrable vida, en todas esas otras arenas no monopolizadas por este dominio securitario, sus gentes viven y hacen sus barrios cada día, los replegan cada noche cuando se van a dormir y los vuelven a desplegar cada mañana, sus frutas exóticas, sus burritos y gorditas ocupando el medio de la calle, Ixs niñxs con sus petardos e inventos caseros, chillidos y alborotos, rancheras y narcocorridos repetitivos y desbordantes de decibelios, con trocas, peseros y bicis compartiendo los centros de las calles, hay de todo, caos y coexistencia, un lugar que descomunalmente me asombra, como cada día el escenario aunque familiar pero distinto se vuelve a inventar. $Y$ me marcho sin apenas haberme percatado, todo tan fugaz que de repente estamos en el avión, con mi amiga del alma pero con el alma fragmentada, con unas doce horas de vuelo restantes para intentar hilar los retazos, mientras esa pantalla de televisión nos muestra virtualmente el paso de nuestro vuelo, imposible, se me quedaron cachitos en ese lugar, mis emociones enmarañadas, tantos cambios en tan poco tiempo, tantos 
espacios convertidos en lugares, tantos miedos en búsqueda de resistencias, sólo daría para configurar un collage con prémula, el puzzle emocional y mental no se conformaría hasta que mis pies descansaran sedentarios en otro lugar, en pocos días estaría viviendo en Budapest, a donde iría además de para completar el segundo año de máster, a tejer otra pieza de ese centón, la historia reescrita en símbolos a través de cada cuadro hilvanado de generación tras generación, una metáfora que representa el pasado, lo que para mi constituye otro fragmento narrativo que da cuenta de mi habitar interno, repleto de vivencias variadas, con sus itinerarios, sus bordes y esquinas, con sus temores, a veces vividos, limitándome, otras veces contestados.

Con todo mi entusiasmo y mis nostalgias del caminar la noche sola me recorro varios kilómetros de Danubio, buscando un barco para vivir, mientras pasaba repaso a todas estas vivencias, tenía que apresurarme porque llegaban otras, mis zapatillas mexicanas gastarían su suela en estos paseos y en la búsqueda de casa flotante, indescriptible la sensación del caminar y caminar tranquila en un lugar nuevo, extraño, sin significado aún, mi cuerpo fluía como sus aguas, hasta que alguien me habló de peligrosidad, esta vez presté mucha atención a los detalles, como siempre hago, claro, pero esta vez para saber qué prejuicios se guardaban más que para interiorizarlo en mi cuerpo. Me hablaban del barrio VIII, el barrio romá, donde gitanxs se habían instaurado, tras haber sido trasladados desde otras zonas tiempo atrás, área donde la pobreza se desprende de las paredes, de los contenedores vacios, ni basura había en ellos, pero sí por la calle, estaba abandonado de servicios, de atención administrativa pero las gentes hacían su vida en las calles, de ese otro modo que me hace sentir tanta curiosidad, desde los márgenes. La persona con la que hacía intercambio lingüístico me decía "si vas allí saldrás fresquita, en bragas, o sin ellas", le pedí que me acompañase, el intercambio de lengua nos hizo compartir muchos secretos, los intereses y los miedos entre otros y a pesar de que él es de aquí sentí como vivía su frontera, ese lugar era un "afuera" para él, nunca cedió, así le 
era posible reproducir todos esos atropellos de prejuicios. Por mucho tiempo los mensajes que recibía eran de este tipo, yo vivía muy cerca, justo en el borde, tanto me atraen estos lugares por lo casual, no sé si yo los elijo o ellos me eligen a mí. Blaha Luijza, ese lugar que divide el distrito siete del ocho, dos universos, arquitectónica, estética, social y económicamente, los dos llenos de vida. Expuesto a un proceso de gentrificación que observo prepotente de alguna forma, nueva gente que va a vivir al barrio, gente "cool" y aunque soy partidaria de las mezclas, de los aires contagiosos de novedad, de ideas imprevistas y súbitas que recorren estos espacios segregados, observo como en muchos casos no es este deseo de interacción, compartir, cohabitar, lo que les mueve a estas generaciones, es en su mayoría, sólo, un lugar con precios más bajos, pero ya no tan bajos como para quienes viven allá porque las condiciones que se someten a más requerimientos, es el vivir en un barrio "excluido" que a muchas personas les comporta de carácter, un carácter a modo de recuadro, en el retrato siguen siendo ellxs, con sus mismas formas, con sus mismos modos, como aquellos turistas americanxs que allá por donde viajan siguen experimentando la gastronomía del mcdonalds, sólo cambian el paisaje, no sus usos, lo único que cambia es ese marco decorativo. En el caso de un amigo que allí vivía así lo contemplaba, no hacía vida de barrio, no se relacionaba en él, no mantenía relación con sus vecinxs. Creo que su caso es extrapolable a muchas personas que van a vivir a estos sitios, donde esas ideas frescas nombradas no se desprenden de sus contactos ni de sus palabras inexistentes, cada unx con la suya propia, así sólo cambia la estética y el sentido de barrio también pero no a modo de mezcla, sino de imposición.

Recuerdo una mañana que me desperté en uno de estos pisitos, separado de cada uno por muy poco espacio, como muy aglutinados, compartiendo un patio central y unos balconcitos con sus barandas y sin cercas, toda unida, un lugar idóneo para el desarrollo de ese sentido de comunidad, para el intercambio pero no era así, no desde mi amigo al resto que es lo que yo tuve más de cerca, aunque estoy segura él pasaba inadvertido pues sólo se relacionaba de 
modo utilitarista, para dormir y estar en casa, sin interacción. Esa mañana con nuestras bicis, la puerta general no entendía de automatismos sino de patadas para abrirla, yo me resistía, intentaba utilizar mi astucia para abrirla de otra forma, un hombre que no caminaba bien se dirigía a la salida a la misma vez, observó mi ensayo y su logro, el pasar Ixs tres y nuestras bicis se hizo aparatoso, no dudé en sujetarle la pesada puerta y que él pasase primero, ese gesto me dedicó una gran sonrisa y unas palabras que aunque mi amigo me tradujo ya no recuerdo, pero sí recuerdo que ese hombre no se olvidó de mi, era fácil, la extranjera, las pocas veces que me lo encontré me miró de manera complaciente. Así creo que hay que entrar en un barrio, cediendo el paso, no rebasándolo.

Recuerdo también que cuando la noche anterior iba a casa de mi amigo, tarde, sin conocer bien el barrio, paré a preguntar orientación a una mujer y tardó poco tiempo en dármela, un poco más en advertirme que tuviese cuidado yo sola de ir por esa zona, aun con bici me decía esto, la bici me provee de fuerza, me siento más segura, pedaleo rápido si es necesario escapar, creo que mis piernas responderían mejor incluso que mis palabras. Me dio miedo porque todo estaba desolado, excepto la calle de mi amigo en la que había ajetreos sospechosos, sospecha que ya se había instaurado en mis pensamientos, y sentí miedo porque llevaba el ordenador conmigo, nunca me han atracado pero puede que algún día me pase y ojalá que sólo sea esto, pero para ello he de prepararme mentalmente, el que me quieran arrebatar algún bien material no es más injusto que la injusticia que a esas otras personas les acontece. Adversa era la foto de la mañana cargada de vida, de sol y de gentes, el mercado emergía a la salida de la casa, un lugar fogoso, colorido. Me hizo pensar en la diferencia de la noche al día, de esa apropiación que la noche hace del miedo, reflexionando acerca de él he llegado a pensar en su significación, como esa puerta que abre en ambos sentidos, quizá es una estrategia que comporta entidad a quienes de ello se valen, les hace sentirse más fuertes frente a la adversidad externa, es una herramienta de poder, la única 
forma en la que pueden apropiarse de lo que en sus barrios pasa, dando miedo, aprovechando este discurso se visten de él, quizá es la única forma en que se sientan empoderadxs, cuando no hay otros instrumentos a su mano, cuando esa minoría silenciada no encuentra forma de efectuar cambios, de que su palabra se escuche solo les queda el miedo, se han dado cuenta de que este es efectivo.

En mi último mes de estancia, meses que se dilataban, quedé abducida por los aconteceres imparables, mi mente se resistía al regreso y cuando me fue posible concretar una fecha con ticket de avión, algo que lo hacía real, tuve un hallazgo, conocí a alguien que como yo tenía gustos por los márgenes, a pesar de que otro amigo y cada uno de ellos, en definitiva, me habían mostrado la Budapest subversiva, éste otro me enseño el margen de los márgenes de la ciudad, allá donde sólo hay carreteras desoladas, con vías del tranvía, vacío, sin restos de ser transitado, campo, oscuridad, hasta que nos tropezamos con alguien, prostitutas en una carretera donde tal vez algún coche pararía, aunque nosotrxs no nos encontramos con ninguno, sólo dos tipos que nos gritaron algo y más lejos ellas dos solas, ahí abocadas a lo remoto, donde ningún grito las salvaría de nada, con ello no digo que necesiten ser salvadas. Mi amigo compartió con ellas algunas palabras amistosas, yo tan sólo pude saludar, el magyar (lengua húngara) sólo me dio para un sobrevivir en la cotidianeidad, palabras sin frases, solo palabras que unía aun sin conectores gramaticales, sí con gestos. Hasta que llegamos a un lugar incierto, en mitad de la nada irrumpía un edificio de pisos sociales, un lugar agreste, sombrío, lóbrego. Allá paramos, mi amigo quería enseñarme el cuadro de cerca, tocarlo y me empezó a señalar los pisos vacíos, tapiados, compartiendo pared con otros ocupados, me preguntaba cómo sería el vivir con muros cercados, salir fuera y sentir lo intranspasable, lo áspero que esos muros simbolizan, prohibición, sospecha, el no uso porque no hay dinero para pagarlo, mejor tapiado. En lugar de generar un deseo de convivencia, generaría otro de violencia, de desapego, de no hacerlo valer. La verdad, su carácter, sucio, oscuro y prohibitivo 
me dio miedo, no me invitaba a estar allí. "Existe el miedo que expresan algunos lugares y existe a su vez el lugar como expresión del miedo" (Merino y Sánchez, 2007). Éste era uno de ellos. Aparte de esta sensación momentánea, diría que Budapest no está muy construida en torno al miedo que se personifica en Ixs gitanxs, quienes cargan con el miedo de la pobreza, de la exclusión, donde se les acusa y reprocha de cobrar ayudas sociales que le son negadas a muchas otras personas de "allí", como si el colectivo romá que lleva viviendo años allá fuese menos de allí. De nuevo la construcción de "otrx" malo, con esta lectura del afuera, "el mal siempre viene de fuera".

Una vez en Granada, de vuelta al Albayzín, un barrio familiar al que quiero mirar con esos ojos de extrañamiento que me evocan los lugares en los que me he movido cuando todavía no estaban dibujados por aconteceres, aun cercano y plagado de emociones, quiero vivirlo en la distancia, cuestionándome sobre prácticas cotidianas y arrancando el esencialismo de las paredes, las que parecían estar allí de siempre, hecho que se ha hecho casi irrealizable hasta el final, con el trabajo de campo. Extraño se hace, desde el principio, sobre todo cuando me dispongo a salir de casa en la mañana, con la actividad diurna planificada pero también dejando un hueco, una grieta de espontaneidad a mis noches, una resistencia lúdica a la monotonía, el momento de hacer inmenso lo que no tiene cabida en tiempo, un todo en pocos minutos, en el que no sé desde que zona, probablemente el Albayzín, regreso sola a casa, un todo en el que también cabe el miedo, que sería eclipsado por el pedaleo de mi bicicleta, pero el Albayzín no es escenario para bicis, con su empedrado característico que también parece estar allí desde siempre. Dudo, acerca de si llevarme la bici o no, de si llevarme el ordenador o no, de esto último no hay vacilación aunque me lo pregunte. Es en este momento cuando me estoy construyendo la vuelta a casa, incluso antes de salir de ella, un ejemplo más de prácticas relacionadas con el miedo, me estoy haciendo un mapa mental de mis rutas, itinerarios que se acortan no sólo en distancia geométrica sino temporal, pienso que la solución sería llegar 
temprano a casa, pero eso da igual, la noche llega pronta en el invierno. La ruta también da igual, las tres formas de llegar a mi casa (dos de ellas en paralelo), son igual de inhóspitas en invierno, en lo que a desérticas se refiere, una es atravesando todo el Albayzín, de abajo a arriba y salir de él por la carretera de Murcia, lugar en el que no hay nada hasta que llego a mi casa, bueno sí, un parking, sólo guarda la presencia de coches o no se sabe qué más porque una vez que lo pasas, la iluminación es más que deficitaria, un no-lugar que no invita ni a su paso. Obviamente la planificación no se ha hecho teniendo en cuenta las necesidades de las personas que viven y transitan esa zona, un lugar para aparcar los coches, aunque allí no los dejan ninguna persona del vecindario, son para quienes vienen a visitar el área, una especie de parking residual, que no acoge a quien tiene que atravesarlo cada día, se prioriza el uso del vehículo (que a quienes conscientemente decidimos no utilizarlo pensando en un bien general). Además está cerrado de un lado por la muralla nazarí, a mis ojos una paradoja simbólica. Una de las otras rutas es a través de la carretera de Murcia, o desde el camino de san Antonio que se cruza con ésta, parajes no más invitadores, ausentes de vida, sus pocas casas parecen vacías, huecas, ni un halo de luz sale por ellas, la carretera de Murcia se decora con alguna casa en ruina, la entrada a los cármenes de Rolando, la rotonda y una vez arriba coches, coches en fila, además de unas vistas sobrecogedoras que me hacen cambiar el sentido del miedo, el miedo se vuelve valiente cuando llego a esa parte. La planificación está abandonada, no existe en estas zonas, o existe desde un punto de vista, el masculino, las mujeres no están ni mucho menos pensadas. 


\section{CARTOGRAFÍAS DEL MIEDO: PERCEPCIONES EN EL ALBAYZÍN}

El miedo es descrito por Teresa del Valle (1999) como "un espacio desolado nocturno impregnado de imágenes que personifican las fuerzas amenazantes", y por las personas entrevistadas como una sensación que paraliza, como un mecanismo de defensa ante una situación peligrosa, una respuesta natural, una alarma que provoca angustia, bloqueo, no sentirse segura, una sensación de impotencia, de encogimiento de barriga y que hace mirar a todos lados y a algunxs les cuesta definirlo porque dicen no sentirlo fácilmente o nunca.

Me interesa el miedo desde una mirada construida social y culturalmente, acercarme a las percepciones del qué teme la gente que vive y transita el Albayzín, y algunos elementos que influyen en ello a modo de características de lugares, en qué momentos, quienes lo sienten y a quienes se teme, y destacar qué hacen con él (o qué nos hace él a nosotrxs), las estrategias de resistencia.

A continuación presentaré a cada una de las personas entrevistadas, intentando trazar una cartografía de sus percepciones en el barrio, en relación con el miedo. 
"SILVIA y el miedo a la incertidumbre, el miedo al miedo"

Mi primera entrevista tiene lugar allá por el invierno, una entrevista dual, a una pareja, me interesaron ambxs, personas que comparten espacio doméstico y sueños con trayectorias personales muy vivificantes y singulares. Una amiga les habla de mi en una cena por los temas de conversación que rondaban y a mi me habla de ellos, mi amiga acuerda una cita y allá nos presentamos, ella se quedaría jugando con la hija de ambxs mientras la entrevista podía tener lugar con un ambiente más distendido entre pasteles árabes (baklavá) y curiosos y sugerentes relatos.

Ella es Silvia, granadina, médica, de 38 años, lleva viviendo en el Albaicín seis años y ha tenido recorridos cuanto menos inusuales. Vivió sus primeros veinte años en la zona de Alhamar y se mudó a Almanjáyar después donde vivió durante diez años, en una zona bastante mal prestigiada: Molino Nuevo. Ha vivido en México, entre otros lugares, una mujer a la que parece que le gustan los riesgos, las aventuras. Silvia cuenta como ella se ha movido libremente por la urbe sin miedos, sin coartadas, de hecho su vivencia en Almanjáyar contagió a otras personas, como su hermana y una amiga que estuvieron viviendo un tiempo con ella, de otra visión del lugar, menguaron su percepción de riesgo, además de Chemi (su pareja) quien comenta que él no se habría imaginado en esta zona hasta que lo hizo y el codearse con el barrio le hizo también alivianar esas ideas de zona de riesgo. Vino a vivir al Albayzín, hace seis años, ella callejeaba autónomamente, como en cualquier otro de sus barrios, pero una experiencia $^{23}$ le ha afectado hasta el punto de que por un tiempo no era capaz de ir por esa

\footnotetext{
${ }^{23}$ Una noche girando desde Calderería a Cuesta Marañas, se tropezó con una mirada que cargaba un bolso en su mano, ella sabía que venía de robar, lo que no sabía es si quería robarle a ella también y su cuerpo indócil echó a correr, en el camino se encontró con un suceso, una mujer que gritaba haber sido apuñalada, Silvia le hizo un torniquete que la salvó mientras llegó el 061.
} 
calle sola, su calle, el Zenete, una mala experiencia que parece haberla impregnado de miedo persistente, un miedo que no se borra aunque sí se difumina.

Silvia no tiene miedo a la agresión sexual como comenta explícitamente, es el miedo a que la retengan, a lo impredecible, ese miedo al miedo que muchas personas podemos sentir.

"En la calle no es que tenga miedo a que me roben porque lo que tengo en el bolso no es... tengo miedo al susto, miedo a tener miedo, porque si luego lo piensas, puede que con 15 años tuviera mas el miedo metío, sobre tó las mujeres a violaciones y eso, pero ahora cuando vuelvo sola no pienso que va a haber un hombre que me quiera violar pero al susto, a que alguien me diga -dame lo q tienes- o a que me agredieran físicamente ¿miedo a ser violada? No es algo q yo piense"

No puede evitar, aunque es consciente de las implicaciones que tiene, el manifestar en qué figura pondría el miedo, le cuesta nombrarlo por la lectura racista que se podría derivar, ya que es un chico joven, de unos 16 años, marroquí, coincidiendo con el protagonista de aquella mala experiencia. A pesar de que ella sabe que el chico no quería hacerle daño, solo robarle, que fue un accidente, también sabe que esa imagen se quedó inmanente en su recuerdo y manifiesta que si se encuentra con un chico con esas características se carga de miedo. También le tiene miedo a alguien que no controle sus impulsos, no a una persona usuaria de drogas, es a alguien con síndrome de abstinencia, con necesidad.

Siempre que volvia de noche tenía que avisar a su pareja para que saliese a la esquina a por ella, vulnerabilidad que se ha ido aplacando con el tiempo y con el nacimiento de su hija, aunque todavía siente reparo en esta calle ya se ha ido mitigando, en un principio como un ejercicio obligado, pues si salía de noche y llegaba a casa caminando no le parecía oportuno avisar a su pareja que estaba cuidando de la niña, aquí pesaba más el tema del cuidado y el 
amor que la propia vulnerabilidad. Cuando ha salido de noche ha regresado en taxi o ha accedido a ser acompañada por amigxs. Sobre todo, intenta racionalizar lo ocurrido.

"CHEMI, sin miedo al miedo"

Tiene unos cuarenta y cinco años, trabaja en cuestiones relacionadas con juventud y es albayzinero de toda la vida.

A diferencia de Silvia, no siente ningún temor urbano, cree que como mucho puede perder algo, que cargue de más valor, como una cámara y cuando la lleva es cuando piensa que no sería un buen día para que le atracasen, pero aun así, él siente que nada tiene que perder, que un robo cotidiano es algo que forma parte de la realidad social que vivimos. A la vez revela:

"le tengo miedo a alguien q pueda hacerme daño a mi, porque si puede hacerle daño a alguien que yo quiero pero a mi no, me siento lo bastante fuerte para poder defender a ese alguien, entonces conclusión, alguien que pueda hacerme daño".

Es interesante cómo esta persona teme a que le hagan daño, lo que repercutiría en un no poder proteger a la persona que quiere, mientras que cree que es una idea remota, no tiene la percepción de que esto pueda ocurrirle.

Chemi expresa estar inmunizado a la sensación de inseguridad porque su socialización transcurrió entre robos frecuentes en los que él vivía la calle como un lugar en que a veces había que pagar tributos, cada uno en función de lo que tenía, él como no llevaba apenas nada, la contribución a su atraco era ínfima, sabía que solo era eso lo que podía perder, situación que extrapola al presente y expresa que el riesgo en el Albayzín es perder el dinero o algún porrazo. 
"El problema es que yo inconscientemente en mi vida no he sentido que mucha gente pudiera hacerme daño [...], yo me encuentro por la calle con un tío con mala pinta, con pinta de agresivo y no pienso q pueda hacerme daño, no siento miedo normalmente, quizá porque con 12 años nos atracaban tos los fines de semana, yo salía con los amiguillos a dar un paseo, tenia 30 pesetas en el bolsillo y nos lo quitaban los chorizos que tenían un año mas que nosotros, que los conocíamos por sus nombres y apellidos muchas veces, porque eran de la calle real y decía pues me ha atracao fulano o mengano, y yo me acostumbre a no interpretar aquello como una cosa peligrosa, sino que era como un peaje, ¿no? Jo, ya nos ha pillao el Cristobal... mi asignación era tan ridícula que no perdia nada, porque le daba al tio un duro que era lo q me quedaba, [...]. Nunca le he pegado a nadie, pero no me ha hecho falta, quizá por la propia seguridad que tengo, y esa seguridad es la que hace que no me ataquen"

Cree que su hermana recibió advertencias más severas que él, tiene un recuerdo vago porque cree que "le entraba por un odio y le salía por el otro", supongo que esto se deberá a que los mensajes que recibía desde las distintas fuerzas socializadoras serían distintas, quizá desde otra posición se le retaba a asumir riesgos, a tomar la calle incluso con los riesgos que conllevaba en términos de pérdida, probablemente fuese una pérdida ínfima que superaba las ganancias de la vivencia en ese espacio, todo lo que eso le aportaba, quizá el grupo de iguales, o quizá otros mensajes sutiles batallaban para que las recomendaciones de su madre no fuesen tan oídas como los oídas de su hermana, tal vez ella, extrapolado a un "ellas" no tenían esas fuerzas contradictorias porque todas las lecciones y mensajes recibidos comportaban un uno e inequívoco modelaje de sus cuerpos obedientes.

Aunque no sienta miedo en la calle, nunca cambió de ruta ni recuerda algún evento desafortunado que le ocurriera a él, sí recuerda como una vez le invadió el miedo estando en la cama, al escuchar un golpe, no sabía lo que era, descartaba la opción del ladrón, era un momento de incomprensión, algo que no controlaba, que probablemente su mente desconocía y ahí no podía asirse de estrategia alguna, porque las otras, las relativas a la calle, aunque no controladas porque la calle es ante todo un espacio de incertidumbres, donde nunca se sabe 
qué puede acontecer, son situaciones pensadas y no le teme, el control no está en la situación aunque él lo exprese así, entiendo que el control está en su mente, en su forma de conceptualizar el riesgo y lo que hace con él.

No conoce de límites espaciales, aunque sí identifica un lugar como inhóspito,

"un callejón estrecho que no tiene ninguna casa, un carril con unas escaleras que están mugrienta, llenas de caca de perro, ahí hay 150 metros sin casa alguna, a mi me parece objetivamente que es un sitio más peligroso a pesar que no recuerdo que hayan atacao allí nunca, toa la gente que he conocido la han atacao en calle Zenete que se supone que es una calle más grande, mas transitada y con muchas viviendas pero si tú me preguntas por mi mapa del miedo yo diría esa calle que si pegas una voz no te escucha nadie, es el único sitio donde nadie te oye de todo el Albayzín",

Este lugar se constituye más como expresión del miedo en cuanto a su arquitectura que como límite corporal.

En cuanto a estrategias él no necesita ninguna, aunque propone, como medidas para otras, la posibilidad de rescatar la figura de un sereno o el llevar silbato, con la conciencia barrial que debería llevar aparejado, propuestas que se han intentado pero que no han sido exitosas.

"A mi personalmente no me hace falta nada pero como lo viven los demás..., yo apostaría por una cámara cada dos metros y un policía cada cinco, creo q se pierde menos libertad con eso q con el miedo, para mi el miedo es lo q mas te anula, mas que la realidad, el miedo a que me apuñalen es peor a que me apuñalen porque vives con el miedo toda la vida, hablamos de pánico, casi prefiero que me apuñalen una vez y no tener miedo el resto de mi vida a estar siempre esperando que me apuñalen cada día, uno detrás de otro", 
"TAMARA y el miedo al invierno"

A Tamara me acerco porque la conozco y sé que es del barrio de toda la vida. Me interesa conocer su percepción a través de lo que le han inculcado, sus recuerdos del barrio, del cambio, si lo ha habido y porque es una chica joven, de unos 28 años que se mueve en la nocturnidad, vive dentro de la "zona prohibida" ${ }^{24 ", ~ j u s t o ~ d e b a j o ~ d e ~ C a r v a j a l e s, ~ e n ~ e l ~ A l b a y z i ́ n ~}$ Bajo. Es estudiante y a la vez profesora de música en su casa. Vive sola en una casa antiquísima, afín a ese apelativo de miedo, donde la entrevista tuvo lugar. Fueron tantas las historias que me contó que esa noche salí de allí más cargada de miedos, accedí a ser acompañada parte del trayecto, por ella y por su perra.

Tamara temería a una agresión física, tampoco menciona la sexual. Presenta una estricta espacialización pese a verbalizar que no se mueve con miedo, su recuerdo se ve condicionado en función de la estación del año, sin duda admite que el invierno es cuando mayor riesgo hay de atracos, desde octubre a febrero, ya que es cuando se necesita más dinero para las facturas y para la navidad, para los regalos, según comenta "siempre me han dicho eso de pequeña". En función de la hora, es a partir de las dos y pico de la mañana cuando puede sentir un incremento de posibilidades, más temprano en el invierno, marca el límite con seguridad cuando yo le cuestiono si a las una y pico de la mañana no, ella establece el horario, una hora no le parece arriesgada. Asimismo en función de las calles, resalta el entramado de calles que

\footnotetext{
${ }^{24}$ Me referiré con este término a las zonificaciones catalogadas de riesgo, las que la gente percibe como lugares a evitar, evocadores de miedo.
} 
son la boca del lobo, siempre presta atención a las salidas que tiene, ella establece que no pasa por San Gregorio en la noche, desde ahí hasta el Huerto del Carlos, con la archimencionada Placeta Nevot en su intervalo, conforman el icono de las calles prohibidas del mapa albayzinero que construyó desde que tiene recuerdos, además de otras como Veteta. Su cartografía del riesgo, por lo tanto, consta de espacios, horas y estaciones "vetadas".

Describe también la situación de hace unos años, cuando se intentaba acabar con la normalización de la delincuencia y los carteles de los vecinos y las sábanas colgadas desde los balcones anunciaban el peligro que a su vez ella entendía como una publicitación del miedo, excesivo, tipo parque temático. Señala como mucha gente se quejaba de aquello interpretando que esas prácticas eran traducidas como la llegada de gente nueva al barrio con un nivel adquisitivo superior y como una imposición en el intento de cambiar el barrio. "Eso no ocurría antes, es una nueva medida adoptada por los nuevos residentes". Con lo cual interpreto cierto rechazo hacia lo nuevo, detrás se lee el mas vale malo conocido que bueno por conocer, pues se está priorizando el que antes no se hacia incluso con los niveles de inseguridad que se manejaban, a nuevos métodos introducidos por gente que no es "del barrio de siempre" aunque eso pueda tener un efecto positivo en cuanto a la reducción de conflictos en este sentido. Interpreto aquí que hay cierto miedo en ese rechazo, un miedo a lo desconocido, desconfianza ante lo nuevo, lo que viene de fuera, lo diferente, el miedo a la alteridad y con ello la pérdida de cierto poder que concede el sentirte albayzinera de toda la vida, un no reconocimiento de las concesiones que te pueda procurar ese estatus.

"Cuando yo era pequeña eran gente del barrio, si tu eras del barrio a ti no te van a atracar, después los vecinos empezaron a actuar, se quitó a esta gente y los que llegaron fueron los niños marroquíes que son los más peligrosos de todos, de 15-16 años, que saben q no les va a pasar nada, esos son los chungos, los agresivos, pero que este año no están". 
A pesar de manifestar mayor inseguridad y violencia en el pasado con aquellas otras agresiones en las que había armas implicadas y una especia de ley de la selva instaurada en sus calles, ella remarca el tema de la peligrosidad de los últimos años en manos de los chicos marroquíes custodiados en el colegio Bermúdez de Castro. A ellos les atribuye la figura del "estrangulador del Albayzín" 25". Otros directamente te agreden con golpes, según lo que ha escuchado.

Me habla también de "Valentín el terror del Albayzín", en primera instancia lo cita como "un chungo" pero en su descripción lo mezcla con jóvenes, de nuevo marroquíes y describe sus actividades delictivas descomunalmente feroces, desde arrojar gente por la baranda de Carvajales hasta lanzar litros o quemarle la casa a un vecino porque les llamó la atención mientras estaban rompiendo una farola. Busco información sobre este personaje y descubro que es un chico del barrio de trece años que tenía atemorizados al vecindario, con un itinerario delincuencial exorbitante, desde agresiones sexuales a menores hasta atracos con arma, allá por el 2004. Tamara lo mezcla con los niños del colegio, de nuevo son ellos el chivo expiatorio, se han ganado una fama merecida y buscada por unos cuantos que se extiende ahora a la generalidad. Con estos relatos se tiende a asociar un chico de quince años con el colegio Bermúdez de castro, con el pegamento (que aunque no lo he nombrado también ha estado presente en varias de las entrevistas) y con la figura de un agresor y violento. Es la construcción de un enemigo, ese que Iván Díez en su estudio acerca del espacio en Sevilla señalaba como las nuevas figuras del miedo, el joven y el inmigrante, en este caso ambas categorías se engloban en una sola.

\footnotetext{
${ }^{25}$ consiste en la técnica del corte de respiración apretando el cuello y te inmoviliza por un momento, cayendo al suelo, momento que aprovechan para desvalijar a la persona.
} 
Tamara no percibe el barrio como inseguro, lo siente familiar aunque indica transitarlo bajo el prisma de la sospecha, hecho este que suena un poco incongruente a mis oídos, ¿cómo puede resultar familiar y seguro algo de lo que desconfiamos?

En cuanto a sus estrategias la primera que advierte es la ya referida atención a su cartografía, así, lo que deslimita los márgenes se convierte en acción, lo que no se ajusta a esa hora, a ese periodo del año y a esas calles, la mantienen libre de movimiento.

"desde que soy pequeña sé por dónde tengo que ir y a qué horas tengo que ir y cómo tengo que ir, a dónde miro, conozco el tema y sé que desde que empiezo a subir la cuesta, primero qué calles no pisar, aunque pienses que no pase ná y de todas formas por la calle que vayas mira a ver y lo ves venir. Mirar qué es lo que tienes a tu alrededor en todo momento y darte cuenta de si ese puede ser o el otro, porque puede ser ese, te persigue y te metes en la boca del lobo, pero si te das cuenta antes de meterte en la boca del lobo te sales, eso yo lo aprendí de chica".

La segunda sería el caminar con la perra, cuando se siente insegura la lleva amarrada junto a ella, es una perra enorme que intimida y si le preguntan si muerde, ella responde afirmativamente, una forma de construir lo que pretende, ahuyentar a otros. La tercera sería el callejear, el saber moverse sobre el terreno. Si observa algo inusual, extraño, se regresa, nunca continúa hacia adelante, rodea y vuelve al lugar. Por último, el uso de la pisada suave, evitar una pisada fuerte, notoria, llamativa, para ser ella la que sorprende, típicos trucos como ella designa, claro que los típicos trucos son diversos dependiendo de la persona. 
"LUNA y el miedo al barrio vacío, sin luz tras las ventanas"

A Luna me acerco por la calle, nos conocemos, ella es de mi pueblo, pero como yo, lleva muchos años fuera, nos conocemos de la ciudad. La entrevista tuvo lugar en su casa en un mediodía de domingo, donde compartimos unas cervezas, un pikislabis, intimidades y lo recóndito. Las horas transcurrieron fugaces. Tiene 53 años y ha vivido la mayor parte en Madrid, tiene una profesión liberal dedicada al mundo de la música. Llegó al Albayzín hace cuatro años, barrio que le parece de inconmensurable belleza, lo cual según ella debiera influir en la afectación del miedo, no debiera ser este un lugar que inspirase este sentimiento, pero no es así, sus calles estrechas, aunque encantadoras también pueden resultar asfixiantes "porque tienes menos margen pá correr, huir o esconderte, no hay margen de maniobra", también las plazas sin bares, ni vida, cuando llega la oscuridad, la noche esconde lo que el día oculta, este momento junto con el elemento de la lluvia, al contrario que Tamara, que la identifica con un momento salvo, encuentran lo propicio para que el temor se manifieste, a lo que además añade:

"lo q no puedo entender es que las ventanas de las casas estén cerradas, recuerdo no hace mucho pasar por cualquier ciudad o pueblo y ver luz en las casas, ahora no. Cuando hace mucho frio pues cierro por mantener la calor pero en general me gusta abrir la ventana y que se vea que hay vida".

Luna, por su parte, tampoco experimenta ese miedo a la violación, consciente, lo que más teme es la agresión física, "nunca he pensado en la violación aunque es algo que tienes en la cabeza 
[...], temo que me peguen una puñalá por 20 euros", es éste un miedo al daño, al dolor, al sufrimiento, a un arrebatamiento físico.

Quizá lo de la violación es una voz que habla sin megáfono, no es notoria pero se deja escuchar, se lleva todo el tiempo en la cabeza, como dice Luna, aun sin pensarse.

Luna expresa que le ha empezado a dar miedo el pueblo, algo que antes solo pertenecía a la ciudad se ha mudado también a este lugar pequeño porque ha sufrido un cambio con la inmigración. Recuerda las voces de su madre advirtiéndole sobre el riesgo de los ecuatorianos y sus hábitos con el alcohol y la violencia hacia sus esposas. Confiesa como esos mensajes han calado dentro de ella, en ese momento ella llegaba de Madrid, de un barrio conflictivo, Lavapiés, ambientado por pandillas de chicos marroquíes esnifando pegamento, donde si que fue agredida en varias ocasiones. A la vez que establece la figura del miedo concreta:

"no son ellos los culpables, pero es el pensamiento de saber que cualquiera que ha cruzao el estrecho en patera, es capaz de cualquier cosa por subsistir, el problema no es la inmigración, el problema son las condiciones con las que se encuentra al llegar o tienen que atravesar pa poder llegar a donde tienen que llegar. Llegaba al pueblo y la gente estaba asustada pero con esto igual que con la gente que iba el esparrago rock, se asustan de lo desconocido pero de alguna manera también te lo inculcan a ti, ¿no?”.

En el pueblo son los ecuatorianos y en Granada los marroquíes, como expone, acorde a las noticias del periódico principalmente, de donde su información deriva, una maquinaria discursiva poderosa que forja la realidad, aunque también esas voces vecinales haciéndose eco, que nombran y definen el entramado, incluso advierten, en la cafetería y hasta en la floristería cumplen aquí una función social, avisar pero también acercar, vincularse. Como dice Sergio García el miedo propio puede reforzar el orden pero también ser motor de sociabilidad, el contar una historia de miedo o alertar puede ser consecuencia de una instrumentalización del discurso dominante para interaccionar con personas que de otra forma no sería posible. 
Ella admite que hay intermitencias, como la vida misma, momentos en los que la gente está más revuelta, más gente necesitada significa más gente buscándose la vida. Ella contrasta este discurso, con su propia verbalización y con sus prácticas, "Lo que cuentan los periódicos es que son los chavales marroquíes. Son rachas, si los niños tienen sus actividades y mas o menos disfrutan con lo que tienen no necesitan salir a alimentar esa parte negra que todos tenemos".

Para Luna la forma de practicar el trazado urbano también atiende a una espacialización de los itinerarios, que quedarán reflejados en la cartografía, sí que remarca la dejadez de sus calles, lo que estaría intrínsecamente relacionado con este sentimiento de temor.

Entre este discurso del Albayzín como zona de arenas movedizas y lo que se interioriza a modo de prácticas en la trama urbana, la espacialización de los itinerarios ${ }^{26}$, se tropieza también con lo que Sergio García denomina las prácticas corporales del miedo. Luna me cuenta como cuando llegó a Madrid, su primer año, el trayecto desde que salía del metro hasta que llegaba al colegio mayor en el que estaba, se subía el cuello de la chaqueta, se escondía el pelo y caminaba como un hombre desgarbado y haciendo ruido con un bastón que lleva, pues tiene un problema con la pierna. En el Albayzín va tosiendo cuando camina por las calles solitarias y también silva, pensando que si alguien está escuchando y el sonido se interrumpe haría que esa persona piense que algo pasa. Al final de la entrevista me entero de que el tosido también es como una forma de mostrarse enferma, cuando me habla de que le tendría miedo a un borracho y el toser sería una forma de equipararse a él. También corre, el ruido es una fórmula que a su mente le mitiga el miedo. Muchas veces sube caminando de manera obligada para contraponerse a ese miedo que percibe y se siente más poderosa cuando llega arriba de la cuesta y ya está al lado de su casa, un ejercicio de empoderamiento.

\footnotetext{
${ }^{26}$ La enumeración de todo ese trazado intransitable y que dibujaré en la cartografía final. Espacialización que también tiene sus tiempos, hasta las nueve de la noche se puede, a las diez u once ya provoca miedo. Señala a su vez la subjetividad coyuntural, como una percepción personal.
} 
"Es un trabajo personal de cada un@ [...] no todos los días de mi vida me levanto con miedo, solo en situaciones muy esporádicamente, - ostias, las cuatro de la mañana, ahora tengo que subir y no tengo un duro, venga vamos! - en el momento que dices -venga vamos- ya no tienes miedo ya lo has superao aunque vengas un poquito cohibida [...] Creo que es un objetivo, el erradicar el miedo de nuestras vidas porque seremos mejores y mas conscientes de cosas que el miedo nos impide ver, voto por NO al miedo".

Otra de sus técnicas utilizada en las disuasión relacionada con el ruido es, una vez que llega a la plaza, donde vive, llama a su perra, es una forma en la que aún fuera ya se siente dentro. No obstante, a pesar de esto relacionado con el ruido, no le gusta que le suene el teléfono. Tampoco ir con falda, le hace sentir más vulnerable. 
"MOHAMMED SY y el miedo a nada"

A la siguiente persona que entrevisto es Mohammed Sy, de 32 años, de Mauritania, musulmán, lleva en Granada cuatro años y dos viviendo en el Albayzín. Nos conocemos desde hace tres años, solíamos estudiar en áreas cercanas, material y académicamente. Es la primera vez que la entrevista tiene lugar en mi casa, en mi habitación, debido a que era la parte más cálida de la casa. Ese día a pesar de estar en mi espacio no me sentí tan cómoda, habría preferido un lugar más neutro. Me hizo pensar en como el espacio moldea o produce sexualidad y configura el deseo. Apuntando de nuevo a Mary Douglas, los espacios obedecen a sistemas ordenados culturalmente, tal vez la habitación estaba fuera de lugar para acometer el propósito de la entrevista.

Mohamed Sy no tiene miedo a nada en relación a la trama urbana, nunca sintió miedo en el Albayzín, nunca. Vive en la Cuesta Alhacaba y sí zonifica sus áreas preferidas, decantándose por espacios más subversivos, fuera de lo turístico, como Plaza de Carvajales y el Huerto del Carlos. "El miedo es la última sensación que me recorre cuando pienso en el Albayzín, por la armonía q me dan sus paseos".

Le sucedieron varios percances, en su país, en los que intentaron robarle y aunque reconoce que sintió miedo en el momento, es algo acerca de lo que ha pensado y que esta reflexión lleva a encontrar un mecanismo de defensa distinto a tener más miedo, reacciona de otra manera, cambiando el punto de vista y entendiéndolo.

Al no sentir miedo a nadie teme, aunque reconoce que en sus primeros días le temía a los borrachos de la calle, cuenta como se le acercó uno para preguntarle por un lugar o algo y él 
salió corriendo. Probablemente estos personajes son bastante inusuales allá de donde él procede. También comenta que el silencio acaparante de alguna calle estrecha le hizo pensar en la posibilidad de que se rompiese con el ladrido de un perro ya que en Mauritania este tipo de situaciones no hay la misma actitud ante los perros y éstos atacan. Aparte de este ínfimo palpitar no hay ningún límite en su transitar por la ciudad ni por el barrio en concreto, sino lo contrario, emoción ante lo desconocido. 
"MARI y el miedo a la invasión de su espacio"

Mari es bailaora, con 34 años, de Málaga y vive en el barrio desde hace unos trece. Nos conocemos por amistades comunes y ha sido mi profesora de flamenco. Elijo que su voz figure porque la considero una persona valiente, siempre me ha parecido una chica transgresora, y esa es una de las motivaciones que me han hecho optar por ciertas personas que aquí se escuchan. Esta entrevista tuvo lugar en una tarde temprana en su casa, entorno a un te, teníamos el tiempo acotado y nos ajustamos a él de una forma casi irreconocible en mi estilo, ella influyó bastante en el ritmo.

No se considera miedosa sino confiada, no experimenta temor por el lugar en que vive, Cuesta Marañas, a pesar de que es señalado como "zona prohibida" por otras personas, ella lo ve muy cercano al centro, apenas ha de atravesar por calles estrechas que quizá sí le darían un poco de miedo, aunque reconoce que conforme se va haciendo mayor se va asiendo de más temores. Antes transitaba cualquier callejón pero ya no se ajusta a esos trazados arriesgados que eran parte de su cotidianeidad, no se ve en la necesidad porque su estilo de vida ha cambiado, no suele caminar sola a altas horas de la noche por el barrio. Si tuviese que atravesar el Albayzín hacia arriba en la noche evitaría el recorrido que en casi todas las entrevistas se señalan: el itinerario de San Gregorio.

Le daría miedo una mirada "sicópata" ${ }^{27 "}$ y la actitud de alguien que intentase invadir su espacio, el acoso físico, también el verbal. No pronuncia nada acerca de la agresión sexual, lo que no significa que no lo "lleve en su cabeza".

\footnotetext{
${ }^{27}$ Ya sea debido a una enfermedad mental o estar bajo el consumo de sustancias, miedo a alguien impredecible.
} 
Este tema lo ha hablado con sus amigas que sí experimentan en sus cuerpos temor a transitar la noche en las calles del Albayzín, pero sus amigos parecen no hablar de esto, quizá porque no existe en ellos o porque el no hablarlo es una forma de hacerlo inexistente o el no ser capaces de reconocerlo.

Menciona a los chicos marroquíes del Colegio Bermúdez de Castro como agentes del miedo pero intuyo que es más un discurso que una realidad vivida, oral, no corporal.

Si siente peligro, que no suele sentir, debido a este estilo de vida que menciona, sin riesgos, se pone las llaves en su mano a modo de arma y camina rápido. En el pasado solía llevar espray. Estos dos elementos que sí están presentes junto al no transitar la tardía noche ni en soledad constituyen sus herramientas en relación con el espacio y el miedo. 
"PAPA M'GOR y el miedo con el que siempre camina"

Caminando una tarde por el Aljibe de la Gitana, en dirección a hacer un ejercicio de observación al Huerto del Carlos y a la Asociación de Vecinxs del Bajo Albayzín, a proponerles una entrevista, me saluda por la calle un chico senegalés al que había conocido anteriormente pero que no recordaba bien y en poco rato estábamos concertando una entrevista para un par de días más tarde. Tiene lugar en mi casa, esta vez atendiendo al sistema clasificatorio simbólico de los espacios, en la sala. No nos conocemos de nada, así que es difícil volcarse en un tema en el que la gente va a hablar de sus miedos sin que le preceda cierto intercambio íntimo. Reconozco que es la entrevista que más fisuras de escape encontraba, a pesar del intento constante de reconducir la entrevista, y la más duradera, surgieron temas acerca de la diferencia cultural en ciertos ámbitos, de la familia, de las creencias e incluso confesiones, producto de una conversación inusual por su parte.

Papa M’Gor tiene 34 años, nació en Dakar, pero lleva en "Europa” desde que tenía once. Es musulmán y buscavidas, vende coches o lo que puede y con ello y con su humor sobrevive, una persona con muchas vivencias. Vive el miedo como algo muy de dentro, con el que ha construido su identidad, una alerta que le hace pensar, le activa a la vez que le pone límites a su asumir riesgos ilimitados, no le paraliza sino que tiene una funcionalidad positiva en su vida.

Tiene miedo a las peleas, a verse abocado a una por estar en el lugar erróneo, en el momento inadecuado. Teme a que le hagan daño, temor que se agudiza cuando va acompañado porque 
eso le hace sentirse responsable y que debe fingir $^{28}$ su miedo y actuar en consecuencia a lo que se espera socialmente de su rol.

Sitúa el miedo en el verano, pues mucha gente local se va, muchas de las relaciones construidas durante el invierno se desmembranan y otra gente de fuera llega, hay un reemplazo de caras que le ponen nervioso, donde se lee cierto rechazo a esos otros desconocidos y hay que empezar de nuevo, con el recelo que eso pueda conllevar, se siente, así, más débil como consecuencia de la pérdida del sentido de comunidad. Esta sensación se reafirma cuando me relata la pérdida de un amigo, una persona que le daba garantías, ir con él era ser respetado y aceptado en todo el barrio, así la pérdida no era solo su amigo, sino lo que perdía con él, el reconocimiento social.

No encuentra límite en su mapa urbano, sus pies no conocen los vetos, aunque hay un lugar que le hace palpitar y prefiere evitar, la calle Conde y para ello hace un recorrido más largo pero esta opción depende de lo que he llamado la subjetividad coyuntural ${ }^{29}$,

"cuando estoy cabreado tomo decisiones que no riman con mi miedo, si me pongo nervioso, lloro y no soy yo quien habla, ese día puedo tomar decisiones distintas, por ejemplo, cuando me entra esta rabia paso por esta ${ }^{30}$ calle y llego hasta el Sacromonte, llevo un sentimiento más fuerte y el miedo no me cala en ese momento".

Y a la inversa, el miedo se hace imperante cuando le otorgamos su lugar.

Si percibe el peligro se da la vuelta, cambia de dirección, a la vez que evita esta calle que no le invita, éstas junto con el uso del teléfono mientras camina por la calle, simula hablar con

\footnotetext{
${ }^{28}$ si alguien le pregunta él nunca dirá que tiene miedo, es consciente de que los mandatos hegemónicos de masculinidad están instaurados en su cuerpo.

${ }^{29}$ La percepción del espacio dependiendo del estado de ánimo de ese momento. Por ejemplo, un día que me siento más fuerte, decido atravesar por el camino más corto, aunque lo perciba como más inseguro y a la inversa, algún día que algo me preocupa, extiendo esa sensación, ensancho mi mapa del miedo.
} 
alguien, en su lengua, woolof, lo cual le provee de cierto poder ya que es una lengua minoritaria. Estas son las prácticas que ejerce en relación con el miedo en la calle.

"MARTA sin miedo pero nunca en la noche"

A Marta la conozco de temas relacionados con su trabajo, una relación más o menos formal y un día comentando acerca de este proyecto me comenta que vive al lado de una de las calles insignia de la zona prohibida, Veteta y le propongo una entrevista, a la que accedió receptivamente. Esta vez tuvo lugar en un bar, el Ízaro, el cual tenía la música bastante alta y ha supuesto un añadido costoso a la transcripción.

Marta tiene 36 años, trabaja en administración y gestión de proyectos, es de un pueblo de la provincia de Granada y lleva viviendo en el barrio unos diez años.

Expresa que si tuviera que ir por los callejones oscuros, por los recovecos en los que no sabes qué te vas a encontrar a la vuelta de la esquina, o subir a la parte alta, a la que explicita ir pero durante horas diurnas, pues si tendría respeto. El camino a su casa es tan corto que no permite que una situación temerosa ocurra, ni imaginariamente. Esto, probablemente, está muy relacionado con sus dinámicas en la ciudad, porque no vive los momentos en los que los fantasmas se despiertan. A la vez pronostica que a partir de las diez de la noche en invierno ya no se sentiría tan segura. De esta forma observo aquí un límite espacial: Veteta y temporal: la noche que no vive, hábito este que de ser distinto, como enuncia, podría llegar a sentir cierto temor.

A Marta le ocurrió una negativa experiencia en las calles nocturnas de su pueblo, un tipo la acosó sexualmente, fue fugaz pues iba acompañada. Tras este incidente sintió un poco de 
sicosis en cualquier calle a cualquier hora, afortunadamente se le pasó y no ha vuelto a sentir miedo. Admite que lo que más temería sería una violación porque si es solo un robo no tiene ningún problema en despojarse de todo lo que lleve.

"Aunque no lo hemos hablado creo que los chicos tienen menos miedo porque desgraciadamente tenemos mas posibilidades de que nos pueda pasar una violación o una agresión, desgraciadamente hay hombres que se creen con la potestad de poder tocarnos, en cualquier momento, cuando a ellos les de la gana, sin conocerte ni nada".

Le temería a una persona con problemas de salud mental pero se retracta por el estigma que esto conlleva y explicita que lo que le daría miedo es alguien fuera de control, impredecible.

Expresa no necesitar estrategia alguna puesto que no vive ese miedo, no se expone a él, así sus estrategias de alguna forma son ese ausentarse de los momentos y los lugares que podrían ser arriesgados conforme a este mapa que muchas mujeres que transitamos el barrio hemos construido. 
"DERK y el miedo a los espacios fríos"

Durante uno de mis peregrinajes al Huerto del Carlos, con la intención de hacer una observación, me encontré con Derk, un chico alemán que sin conocerme me saludó a modo de ser una cara nueva por allí. Empezamos a hablar y aunque yo andaba buscando una chica, joven que no encontraba, terminé por proponerle una entrevista a él. Quedamos unas semanas más tarde para la entrevista, allí en el mismo lugar.

Es un chico alemán, al que olvidé preguntarle su edad, pero alrededor de unos 30 . Lleva nueve años viviendo en Granada, entre Albayzín y Sacromonte y siete instaurado en el Aljibe de Trillo donde además de vivir tiene su consulta, es masajista. Es una persona muy espiritual y que ha pensado mucho acerca de este tema.

Derk habla de muchos pequeños miedos que se compendian en un gran miedo: el miedo a la muerte, el que incluiría todos los demás.

Dice temerle a los lugares fríos, funcionales, donde las relaciones están desintegradas, nombra como ejemplo el Camino de Ronda y siente más miedo en los grandes cúmulos de gente, en manifestaciones o Semana Santa, a la vez que puede ser emocionante, piensa que una masa de gente es impredecible. Reconoce que hay ciertos lugares que no le invitan,

"por condicionamientos personales, por alguna experiencia, por la gente q hay en ese lugar, como Plaza Carvajales, donde hay muchos borrachos, una energía q no me atrae, aquí no me quedo. Plaza nueva me gusta pero no para estar mucho tiempo, los lugares turísticos tienen algo de frio, acoger al turista de cierto tipo se hace con distancia, no es el querer 
conocerles, sino el sacar dinero, también algunos callejones muy deteriorados, muy sucios y muy estrechos, debajo del Zenete hacia calle Elvira, nadie lo cuida".

A diferencia de la mayoría de las personas entrevistadas que experimentan miedo, la noche le provee de calma.

Expresa su malestar acerca de la poca libertad en el espacio publico, la restricción de la música cuando hay muchos otros ruidos mas desagradables, cuando los coches y otros ruidos si están autorizados y cuenta como ha llegado la policía y les han quitado los instrumentos, él le tiene miedo a perder su violín, no se atreve a sacarlo porque piensa que la policía se lo va a quitar, tiene miedo a la reacción de la policía, al sentirse subordinado frente a ellos, a que su opinión no cuente, a las relaciones de poder que de ahí se desprendan. Así parece que su miedo está más relacionado con la pérdida de poder.

Derk no localiza el miedo en una figura, aunque yo me atrevería a inferir que la policía podría ser una de ellas por lo que se desprende de la conversación, a la vez que las grandes masas de gente, sino que lo posiciona dentro de las personas, habla de la construcción de enemigos comunes, cabezas de turco,

"la gente busca sus miedos y los vive. Si necesitan tener miedo de algo lo inventan, por ejemplo el III Reich en Alemania, se dijo que los judíos tienen la culpa de nuestro malestar, uno se siente mejor exteriorizar y coger algo que tenga la culpa, un enemigo y tomarlo como el culpable, se busca en el exterior el darle nombres parar ordenar el mundo mejor porque con el caos y el desorden no se siente bien".

Cuando siente miedo, respira. A pesar de que ha vivido varias experiencia en su calle, ocurridas a otras personas, no siente el peligro en su piel, su técnica disuasoria del miedo es la reflexión, el imaginarse las situaciones y el cómo él reaccionaria, una forma de anticiparse al miedo, una forma de aprender a gestionarlo, una forma de posicionarse ante el mundo, "una oportunidad para comprender mejor, no cargarte de más odio, ni de más miedo, sino de entendimiento". 
Entiendo que es esta una forma de responsabilizar individualmente a las gentes de sus miedos que no atiende a particularidades y ni mucho menos a la socialización de género respecto al miedo.

"PAULA y el miedo que encoge la barriga"

A Paula la conozco desde hace años, tenemos amigas comunes y también me ha parecido como Mari una de esas voces transgresoras, una de esas mujeres que rescatan la noche como propia. Nos encontramos en una terraza, haciendo elogio a la primavera granaina, a las faldas del barrio, en calle Elvira, con todo ese fluir de gentes, cuyo rumor dejo constancia en el fondo de la entrevista.

Paula es granadina, de 36 años, procede de los Alminares, un barrio cercano al centro, pero lleva viviendo trece años en el Albayzín, en lugares muy variados.

Habla de ese estado de alarma que vive en casi todas nosotras, "por ser mujer he tenido la sensación de alerta toda mi vida". Tiene miedo a que le roben, pero sobre todo a una agresión sexual y a que le hagan daño.

Estos miedos eran compartidos con sus amigas aunque ya no habla sobre ello, quizás porque sus hábitos callejeros han cambiado, pero considera que estos miedos en la ciudad son comunes a muchas aun con todas las particularidades que implican las experiencias e itinerarios personales. Al contrario sus amigos, quienes pueden sentirlo, aunque no lo manifiesten, pero considera que son otros motivadores los que les proveen de esta sensación de temor, como la posibilidad de perder algo de valor que acarreen, pero recalca como ellos no tienen el miedo a la agresión sexual que todas nosotras cargamos. Para ellos actos relativos a la agresión pueden ser una "gracia" o una "tontería", desde el que alguien te toque el culo, hasta que alguien te grite desde un coche, pueden ser insignificantes a muchos ojos enfrascados en este sistema que no los contempla como acosos sino como "minucieses", 
formas y miradas legitimadas de reproducir la infravaloración hacia las mujeres, prácticas estas que enmarcan la violencia y que ni sus emisores son conscientes, en muchos casos, de lo que eso supone, al estar tan insertas y naturalizadas. El miedo es así un resultado de este sistema, aunque añadiría que también es un recurso, con el que cuenta para erigir su poder. "Caminar sin alerta no será posible, pero sin miedo depende, se requiere empoderamiento”.

Paula hace mucho que dice no experimentar miedo, de ese que le contrae por dentro, y pasa por donde le parece pero a la vez dice preparar la ruta a priori, no improvisa, lo tiene en cuenta antes de emprenderlo, su mapa como el de la mayoría de las mujeres, está preconfigurado y lo atiende con alerta, hace hincapié en que siempre va con ella. Imagino se refiere a que su mapa antes era un poco más estricto, menos improvisado, me cuenta como dependiendo de la hora elegía una ruta u otra, "Cuando vivía en la Tiña me iba por los callejones de San José en lugar de San Gregorio, eso si subo a las doce de la noche, si subo a las cuatro de la mañana subo por cualquier lado. A día de hoy subo por donde sea”. Aun así, manifiesta no sentirse segura en la zona de San Gregorio y sus aledaños, y enumera algunas otras calles, entre ellas la Cuesta Chapiz porque es donde está el Centro de Acogimiento de los niños marroquíes y es una ruta de turistas. Al contrario, la zona de San Bartolomé, y alguna otra le parece más seguro ya que es un área sin tanto turismo y donde hay más vecindad, más comunidad. Describe los lugares donde se plasma el miedo y estos son los callejones estrechos, las zonas donde hay menos viviendas y donde hay poca gente o una persona sola. También manifiesta como el Albayzín lo siente más seguro que otros barrios donde ha vivido como los Alminares y el Realejo.

Paula no personifica la figura del miedo, aunque menciona también a los niños marroquíes, como Mari, por la manera en que lo hace, me da la impresión que forma parte más de un discurso que de su realidad. 
Si experimenta miedo camina más rápido o más lento, dependiendo de si hay gente o no, desvía el camino, cambia la ruta dependiendo de la hora y a veces le da más valentía, un momento en que se aferra a pensamientos reforzantes, una dosis contra un instante de inseguridad, cuenta como con sus amigas, cuando había muchos ataques, allá por el 2005, se preparaban antes de entrar en la "zona del terror ${ }^{31 "}$ con los puños en alto preparados y decididas a defenderse si alguien quería coartarles su libre transitar, pero no evitaban correr, a pesar de ir varias. Otra de sus prácticas en relación al miedo era quitarse las joyas, ya que acostumbra a llevar mucha plata, el ser lo menos notoria posible.

\footnotetext{
${ }^{31}$ Me refiero a la "zona prohibida", alrededor de San Gregorio, la llamo así por darle ímpetu a aquel momento en el que ocurrían altercadas cotidianamente, protagonizados según la mayoría de la gente por los niños marroquíes. La Asociación de Vecinxs del Bajo Albayzín llegaron a registrar cada uno de estos incidentes de los que tuvieron constancia, publicándolos en su blog semanal.
} 
"PACO y el miedo al desempoderamiento del cuerpo por la edad"

Quise acercarme a la Asociación de Vecinxs del Bajo Albayzín, dado que es un punto de encuentro del barrio, un lugar desde el que se ha trabajado el tema de la seguridad y así aproximarme a cómo éste ha ido cambiando respecto al tema del miedo, cuales son las voces que se escuchan desde ese lugar, qué ocurre en el barrio, dado que es un lugar en el que la gente denuncia, conocer su percepción acerca de quienes temen ya quienes se les teme, qué se ha hecho con eso en términos de mediación entre el vecindario y las autoridades, que medidas o propuestas aportan, estrategias comunes, además de conocer de leyendas que la gente cuenta en torno al barrio, por ser un lugar de múltiples presencias, de clamores plurales.

Paco no experimenta miedo, no le teme ni a las personas ni a la calle, dado que no ha tenido ninguna mala experiencia después de tantos años de recorrer sus recónditas noches de callejones estrechos. Cree que lo único que le podría pasar es un atraco, y le temería que fuese con un arma o con violencia, además de creer que una persona mayor es más vulnerable, "si atacan a un hombre, atacan a uno que sea mas débil que ellos, y por eso podrán atacar a una persona mayor antes que a un joven, porque el joven puede responder mas fácilmente". No especifica acerca de las mujeres pero intuyo que ellas, todas, están dentro de la misma categoría que supone hombre mayor.

Señala el principio de los atracos cuando se da el cambio en la estructura del barrio, alrededor de los años setenta pero no los personifica en nadie, hasta llegar al 2007 donde si encuentran una figura clara: los niños marroquíes del Bermúdez de Castro, que atacaban y atracaban a 
plena luz del día y masivamente, a mujeres, mayores sobre todo, pero también hombres, fecha que se extendería hasta el 2010, desde cuando se goza de más tranquilidad que atribuye a que hay menos niños y más controlados, además de que la llegada de jóvenes de otros países como Rumanía cree mantener las rencillas en casa. No obstante Paco atribuye responsabilidad al colegio en tanto en cuanto no es escuela sino solo acogimiento sin parte educativa, al menos antes y parte de un proceso inacabado, "a partir de los dieciocho años les echaban, algunos se iban a su país otros se quedaban y esos pegaban tirones, y de los que iban y venían ha habido casos celebres, como el estrangulador del albayzin ${ }^{32}$, hará dos o tres años”.

Es patente el efecto que este colegio, con quienes lo integran ha traído al barrio, aparece como uno de los ejes del mal en casi todas las entrevistas, aunque distintas personas lo han dotado con distinto carácter, con distintos motivos de causalidad. Paco admite que "se sigue temiendo a los niños marroquíes, han dejado una renta aun recordable". Aunque hayan sido unos pocos, ellos le han dado nombre a un todo, por el tremendismo de sus actuaciones, que estuvieron latentes durante unos tres años, pero la historia de atracos del Albayzín es larga y diversa, aunque tendemos a recordar lo más significativo por su importancia, que no considero es solo debido a este carácter mencionado sino que también influye el que vienen de fuera.

\footnotetext{
${ }^{32}$ Su llamativo nombre me estremeció, trayéndome a la memoria a los antiguos jugadores de lucha libre con sus funestos seudónimos. Busqué algo de información y lo que hallé fue que de los nueve casos en los que aparece su rastro, siete sucedieron fuera del Albayzín, lo cual me hacía preguntarme acerca del origen de su apelativo y parece que este es debido a la procedencia, se asignó al Colegio Bermúdez de Castro, aunque el chico al que acusaban tenía veinte años y ya estaba desvinculado del centro, pero el mero hecho de su original ligazón a éste le hacía cargar con un nombre que hace referencia a un barrio que se ornamenta no solo de su belleza paisajística sino a su vez de este tipo de figuras. Esta información se deriva de periódicos y por lo que distintas opiniones me transmitieron entiendo que no es solo uno, sino que es una técnica exitosa de la que hacen ejercicio distintos sujetos, y efectivamente en varias de las entrevistas lo han localizado alrededor del Aljibe de Trillo, pero hay que recordar que también transitan por otras partes de la ciudad, cuyos nombres no suenan y reconozco que me hace erigir cierto enojo, pues concede al barrio mayor peligrosidad que a otros lugares.
} 
Paco enumera los lugares que componen la zona prohibida ${ }^{33}$, la zonificación del miedo en el barrio, pero a pesar de mencionarlos, no le afectan, cuando me cuenta el trayecto a su casa me doy cuenta de que pasa por el mismo sitio que antes me había establecido como lugar a evitar, no resultan un límite para él.

¿Estrategias?, no son necesarias para él.

"LOLA y el miedo a la vida de paso del barrio"

Anduve a la caza de Lola, también forma parte de la Asociación de Vecinxs y que Paco bien me habían recomendado entrevistar, tras varios intentos por fin nos encontramos y dada la cercanía que nos adentra en varias conversaciones con sus risas anexas, comenzamos una entrevista en la que me olvido de situarla, sé que trabaja en la Universidad de Ciencias Económicas pero me olvido de preguntarle su edad (calculo que alrededor de los 55) y el tiempo que lleva en la Asociación, sé que no es del barrio, creo que procede de la zona del Beiro aunque recuerdo este dato vagamente. Llegó al Albayzín allá por los años ochenta y a pesar de su integración e implicación en los menesteres del barrio, en algún comentario se desprende la separación de la persona albayzinera de toda la vida y quienes llegaron luego, notoria diferencia que ha sido remarcada muchas veces por autoctonxs.

Le tendría miedo a un asalto con violencia pero no muestra miedo, tal vez no se expone a esos lugares que ella viste con tales características.

Nombra a los niños marroquíes de nuevo como figuras del miedo y me cuenta una anécdota: una tarde hablando con un vecino en la zona de la Mancha Chica, por el Huerto del Carlos, se despidió e iba dirección Calderería, cuando se cruzó con un grupo de chicos marroquíes en una de las esquinas, ella sintió miedo y entablo de nuevo conversación con su vecino desde la

\footnotetext{
${ }^{33}$ Aparecerá en la cartografía
} 
lejanía, cuando se dio la vuelta ellos ya no estaban, pero si aún hubieran estado allí, confiesa que no habría pasado por esa calle.

Lola declara que si apareciese alguien sospechoso pues cambiaría la ruta y también sabría por donde ir, su familiaridad le hace sentirse segura, aunque no me especifica sus usos en el espacio que probablemente están sujetos a horarios y calles, cuenta como algunas veces se ha subido caminando en la noche, sola, me da la impresión que esto es una excepcionalidad y no la norma, aunque mantiene que más que por miedo el no subir es por la distancia y prefiere tomar un taxi. Se la percibe una mujer muy decidida y pienso que esto es básico para asumir esa libertad de movimientos.

Me cuenta también acerca de las manifestaciones desde allí organizadas y me cuenta cómo el tema de la campaña de las pancartas ocasionó controversia, gente en contra que pensaba que era perjudicial (a sus negocios), pero otro grupo cansado de que las administraciones competentes no tomasen medidas decidieron salir en prensa, lo que parecía como la única forma de que fuesen escuchadxs. Admite como la presencia policial es disuasoria y que no es suficiente que vengan ni en coche ni en moto, sino una peatonalmente. Desde la Asociación se ha solicitado por un lado que se denuncie, que es la forma de efectuar cambios, por otro, un pequeño retén policial, no solo con una funcionalidad prestablecida para cuando vienen al barrio, me da varios ejemplos de situaciones de inefectividad, se requiere otras funciones reguladoras más holísticas, desde prestar atención a una farola rota o un contenedor volcado a conocer a Ixs vecinxs y las necesidades del barrio. Establece como estrategia comunitaria, indirectamente, el Derecho a la Ciudad. 
"CHARI y el miedo a los pies negros"

Chari es archiconocida en el Albayzín Alto, yo solo la conocía por la tienda que tiene en la Calle del Agua pero nunca había intercambiado con ella una palabra fuera de ese ámbito. Conozco a su marido que a pesar de no ser del barrio "de toda la vida" tiene su fama por el bar en el que trabaja, el Torcuato y por ser pareja de una mujer autóctona. En varios encuentros cotidianos me preguntaba que hacia y cuando hablé de esto él no tardó en darme su opinión y la de su mujer. Pasé a concertar una posible cita con ella, ese día ya estuvimos charlando sobre el barrio durante un par de horas y días más tarde esta fue llevada a cabo en la puerta de la tienda, en la misma Calle del Agua, con gente pasando pero he de advertir que ella, aun atendiendo la tienda, tuvo una gran capacidad para estar dentro de la entrevista, sin dejar de saludar, note como está acostumbrada a un nivel alto de estímulo y atención a la vez. Su marido, Antonio, también participaba momentáneamente dando su opinión.

Olvidé preguntarle su edad, dado que nos fue fácil adentrarnos en el tema concreto, imagino que alrededor de los 50 años y vive en la misma casa donde nació. Me contó innumerables detalles e historias acerca de esa calle y de quienes la transitan.

Le tiene miedo a la agresión física al mismo nivel que una violación, "una no es más que la otra". 
Manifiesta sentirse segura en el Albayzín Alto, pero no en el Bajo, todos esos callejones le aterran y de noche no pasaría por ahí. Comenta un hecho acaecido en el que una vecina fue asesinada en ese tramo, desde el Bajo al Alto, a la altura de "La Virgencica" ${ }^{44 " ~ h a c e ~ y a ~ m a ́ s ~ d e ~}$ veinte años, pero en su memoria aún está presente cuando camina por ahí. Encuentra una limitación absoluta, no sería capaz de pasar por la Calderería de noche bajo ningún concepto, sola no lo contempla, en el caso de que esto ocurriera ella se imagina acompañada, y aún así dice que tendría miedo pero que como herramienta para intentar aminorar esa sensación caminaría más rápido y que se pondría las llaves en la mano, una de ellas le serviría como arma, por ser una grande y puntiaguda.

Chari y Antonio aluden a los niños marroquíes procurando quitarle importancia, apuntando que "probablemente son unos pocos que dan fama al todos", a la vez que disuaden a unos, responsabilizan a otros, así la figura que a ella le provocaría miedo sería la de "los pies negros, un greñuo ${ }^{35}$ [...], uno que lleve malas pintas aunque puede ser que sea mejor persona que uno que va con traje", me describe a alguien con características del tipo que frecuenta el Huerto del Carlos. Antonio añade el perfil de los senegaleses, dice no entender su uso en la calle y como la policía no les pide los papeles, se queja del consumo que hacen de marihuana y "litros" en Plaza Larga, con Ixs niñxs allí y le parece inapropiado, a la vez que les considera responsables del destrozo ${ }^{36}$ que según él han hecho en el Huerto del Carlos, a la vez que cree que pueden ser buena gente, que no se meten con nadie, "fuman sus porros y hacen su música" pero les

\footnotetext{
${ }^{34}$ Así denomina la gente del barrio a la zona donde hay un pequeño altar a la Virgen de las Angustias, justo al pasar la Placeta Nevot.

${ }^{35}$ No fue la única que menciono este perfil como figura atemorizante, lo escuche en otras voces, en concreto recuerdo a una mujer que trabaja en un edificio de la Universidad frente a la Asociación de Vecinxs del Bajo Albayzín, vive en Maracena y viene cada día pero el camino cuando sale se le hace insoportable si va sola, pues le tiene miedo a chicos que visten como "hippies". Su paso por el barrio siempre está ordenado por la prisa que le profesan sus alientos por salir cuanto antes de esos callejones. Una limitación cotidiana en base a un imaginario estrictamente encorsetado.

${ }^{36}$ Este mal uso de este parque ha sido nombrado también por Lola de la Asociación, la que conoce de las quejas del vecindario, acerca del mal olor procedente de la orina, sobre todo en la plaza del convento y en el callejón que va a Dar'Al Ahorra, además del incesante ruido de instrumentos. Un lugar estigmatizado para muchas personas.
} 
cuestiona su financiamiento, se pone a si mismo como ejemplo de trabajador para pagarse sus vicios, sin embargo ellos no son vistos como trabajadores.

"ANA y el miedo en las entrañas, desafiado por sus pies"

El tema a la violación no es algo que me ronde por dentro cuando transito el espacio urbano, no lo pienso, alguna vez algo me ha podido evocar su recuerdo, algún lugar en el que sabes que el cuerpo de las mujeres está ahí como más disponible, como en México ${ }^{37}$, aunque no hay que irse tan lejos, las posibilidades están en casi cualquier lugar aquí también se observa aunque toman otras formas menos obvias, como por ejemplo pasar por delante de un grupo de hombres y escuchar los comentarios/piropos, a veces ni hacen falta, una mirada habla por sí sola, una expresión corporal, pero en general no es un miedo que a mi me recorra por dentro en mi cotidianeidad, cuando mis miedos juegan a inventarse.. Lo he pensado en varios momentos porque también hemos recibido numerosas advertencias al respecto, indirectamente en mi caso, y he pensado en estrategias al respecto, un "si me viese en la situación, debería hacer ...", un intento de anticiparte, para hacerte de herramientas, pero reconozco que no es algo que extreme mi miedo, el que es más físico, sino que es más un miedo al miedo, ese que mencionaba Silvia, a que alguien interrumpa mis pasos haciendo elogio de poder y en última

\footnotetext{
${ }^{37}$ el hecho de que haya un vagón exclusivamente para las mujeres implica que hay mayor probabilidad de tocamientos y abusos, además de que se respira esta accesibilidad a los cuerpos de las mujeres de muchas otras formas, como si el cuerpo de una mujer valiese menos que el de un hombre o muchos hombres entendiesen que tienen como finalidad saciar las necesidades testosterónicas.
} 
instancia, un miedo a una agresión de cualquier tipo, a una que se prolongue en el tiempo o que sea muy violenta.

Crecí con el temor al "desconocido", un hombre siempre, que me quisiese sucumbir con algo, aunque a día de hoy no podría personificar la figura del miedo en alguien concreto, sino en una actitud, una forma de comportarse más que una apariencia, la forma de mirar, de caminar, de relacionarse con el espacio sería algo que me haría pensar en que esa persona me inspira temor. El pensamiento de Frederik Barth ${ }^{38}$ respecto a que las fronteras no son trazadas para separar las diferencias, sino que son estas, una vez delineadas las que construyen las diferencias, es extrapolable al miedo y a sus enemigos, a éstos los inventamos más tarde para legitimar nuestro miedo.

Mi mapa del miedo, como comenté en la autoetnografía esta extendido, en los distintos caminos nada invitadores de que llevan a mi casa, cargados de oscuridad y soledad. No temía a la Cuesta San Gregorio, sí a la ruta a posteriori, desde la Virgencica hasta la Plaza Larga, aunque a veces se puede extender hasta la propia casa, pues todo ese trayecto en la nocturnidad del invierno está totalmente desolado. Admito que este mapa es maleable no es fijo, y es influenciado por la subjetividad coyuntural momentánea.

Como práctica relacionada con el miedo he utilizado la técnica del difuminar mi cuerpo de mujer en uno más híbrido, cuando en la nocturnidad del otoño o invierno me coloco la capucha de la sudadera y guardo mi pelo dentro, camino rápido además de para reducir mi estancia en ese espacio, para que no se distinga a quién pertenecen esos movimientos, confundir es lo que busco, camuflarme. Lo que interpreto como una forma de asumir aquello de que los hombres están más legitimados para deambular por el espacio público. Pensamiento que a la vez me llena de rabia y me empodera mentalmente para dar más autonomía a mis pasos, así mi miedo tiene esta doble propiedad, me hace ir más rápido a la vez que me carga de mayor fuerza, me agarra más al suelo y a veces voy redactando un discurso mental para esa persona que me

\footnotetext{
${ }^{38}$ En Bauman, Zygmunt.
} 
pueda agredir, a lo menos sorprender, es un discurso feminista. Reflexiono en que nosotras somos vistas como posibles víctimas, como presas fáciles, no se cree de nosotras el que podamos pugnarles, no se espera de nosotras, de ellos no se sabe, se recela. Es esa ira de saber que en el fondo no es solo el miedo a la agresión, al daño, al dolor, ya que considero ostentar más riesgos para experimentar una posible caída, con su respectivo dolor, cuando desciendo la cuesta con la bici a velocidades desorbitantes, esta no es una alerta que me pare sino que me agudiza la vista, es mi mayor miedo, en definitiva, el miedo a la dominación, un miedo que está grabado en los poros y que a veces sin saber porqué, en alguna situación se filtra por mi cuerpo y éste reacciona, y me lleno de miedo pero también de coraje, y en esos momentos pienso "-ayy del pobre que se acerque, me robará, pero no se irá sin discurso-“. Quizá me quede bloqueada, no se sabe pero este pensamiento me fortalece, es una forma de empoderarme. Cantar también me da fuerza.

Durante este trabajo de campo, en los ires y venires deslizantes por sus calles empedradas, piedras con memoria, que solo por el valor que tienen no me permito que alguien me limite el pisarlas, los atajos, los silencios, la exaltación ante un balcón que nunca antes había visto, una alhambra que resurge en el intersticio de unas casas a las que se le cae la cal a cachos, esa sorpresa tras la esquina, un paisaje lleno de pálpitos, de emoción. Todo ello me reafirma en que éste es mi lugar y junto a ese coraje del que hablaba antes me cargo de ímpetu para salir en la noche, para transitarla como yo quiera, más rápido si tengo frío, prisa o siento alerta o más lento si me regocijo con lo que ese lugar me evoca, con mi ritmo inajustable a los relojes. Ese coraje es el que a la vez me hace sentirme autorizada, me infunde agencia. $Y$ de camino a casa, guardaba la grabadora en los calentadores si los llevaba o en las bragas, porque aunque mi mente contemplaba la posibilidad de negociar con ese que intentase arrebatarme mis bienes, la grabadora era irrefutable. Incluso me preguntaba si en lugar del sermón que mi mente maceraba no sería más productivo hacerle unas preguntas, acercarme a su punto de 
vista. Y aunque suena delirante, llegó un día en que tuvo lugar, cuando ya dejé de pensarlo, conocí a un atracador, a uno de esos archimencionados por muchas de las voces que en este trabajo aparecen.

\section{CONCLUSIONES}

El Albayzín, fue siempre un barrio de gente humilde, representado por muchas personas como un pueblo, donde la gente se conocía y entablaba relaciones de ayuda mutua, donde Ixs niñxs jugaban en la calle, un lugar vivo, desprestigiado por la miseria, como comenta Paco y por ser lugar de paso al Sacromonte por el que pasaban Ixs gitanxs, que siempre estuvieron devaluadxs. Fue este carácter de relaciones y unicidad, distinto de otros barrios, lo que le otorgó el reconocimiento de la Unesco como Patrimonio Cultural de la Humanidad allá por el 1994, lo que si atrajo a mayor afluencia, sobre todo de extranjeros y profesionales, a la vez que la gente de aquí se trasladaba a "barrios modernos" como el Zaidín o la Chana, lo que acarreo un proceso de despoblación continuo, localizado estable a día de hoy. Esto trajo episodios puntuales de violencia, por un lado debido al vaciamiento que iba sufriendo el barrio y por otro con la llegada de estxs nuevxs vecinxs y transeúntes, desconocidos y con un nivel adquisitivo mayor. Parece ser, según las percepciones de algunas personas autóctonas que antes no se sucedían estas situaciones relacionadas con la inseguridad sino que son el producto de esos cambios acontecidos. 
Se ha señalado el fenómeno de la despoblación, debido a las míseras condiciones de las viviendas junto con el característico trazado único de muchas calles, en el que solo es posible acceder caminando, que afecta a personas de una edad avanzada o con dificultad de movimientos, lo que ha llevado a un proceso de gentrificación, fruto de ese proceso de reurbanización iniciado con la concesión de título de patrimonio, que convierte el barrio en un lugar demandado para un tipo de población concreta, ya que como comenta Lola, se están construyendo viviendas (apartamentos) para una población que va de paso.

"con apartamentos pequeños que acogen a lo sumo a una pareja pero no casas para familias o alguien que viene a quedarse. Muchas de las viviendas se están transformando en hoteles o apartamentos turísticos. A la vez, hay una carencia de servicios, te encuentras tiendas de artesanías, hoteles y bares que el vecino no necesita"

Así, despoblación, desmembramiento de las redes sociales e inseguridad parecen ir de la mano, provocando un miedo acusante señalado por muchxs vecinxs, lo que a su vez lleva a que el fenómeno siga su curso, más gente se traslada a otras zonas como consecuencia, un rumbo contrario a su posible solución, un barrio más vivo, más cuidado pasaría por un barrio con más gente, sin casas vacías, deteriorándose, afectando no solo a la economía local, a lo social, a lo urbano, a la seguridad.

El barrio del Albayzín se construyó con una imagen a la vez que romántica, estigmatizada, y para paliar ese estigma se crean estrategias para domesticar los temores, a la vez que se buscan enemigos públicos. Como diría Iban Diez, el miedo y la sensación de inseguridad parecen preceder al rechazo al "otro", primero aparece el miedo y después se construye al enemigo, lo personificamos. Aquí los enemigos mayoritariamente mencionados son los niños marroquíes del Colegio Bermúdez de Castro, los "otros", los de "afuera". 
El discurso de la inseguridad en el Albayzín es un discurso antiotros, los que no son del barrio, los que vienen de fuera y sobre todo, los que se asocian a la pobreza, en este caso personas pobres son potencialmente más peligrosas a los ojos de muchas personas que han asumido un discurso hegemónico, aquel que equipara pobreza a peligro. En el barrio los senegaleses están mal vistos, la gente se cuestiona constantemente a qué se dedican, lo que se lee en sus palabras es que al no tener un trabajo estable visible y ser negros están asociados a la delincuencia.

Y en ese encuentro con la alteridad podemos encontrar otra vertiente, como Mohammed Sy asevera, el no tener miedo le ha hecho posible relacionarse con gente muy distinta, salvado de estereotipos, lo que le permite moverse libremente por el espacio, incluso algunos muy distintos al suyo, tan distintos como esas personas diferentes con las que se mueve, lo cual describe como enriquecedor, lo que Bauman ha definido como mixofilia. Así él asocia el miedo en lo urbano a la carencia de interacción con otras personas desconocidas que coinciden en espacio y tiempo, la mixofobia..

Lo que sí es común en todxs Ixs informantes es que la figura del miedo se personifica en un cuerpo de hombre, tanto hombres como mujeres temen a otro hombre.

Mientras que las estadísticas de crímenes reportados en algunos estudios (Massye \& Prike, 1999) muestran que son los chicos jóvenes los más propensos ${ }^{39}$ a experimentar violencias en los espacios públicos, son las mujeres quienes más miedo expresan ${ }^{40}$, dinámica aplicable al Albayzín, entre las personas entrevistadas son ellas las que más temor manifiestan, aun no teniendo esas cifras en relación a las víctimas, cifras que no serían funcionales a ninguna escala, dado que la percepción del miedo es subjetiva y son otros elementos los que la

\footnotetext{
${ }^{39}$ Quizá se puede justificar por el hecho de que son mayormente ellos quienes hacen uso de ese espacio a altas horas de la noche cuando dichos incidentes ocurren.

${ }^{40}$ Las estadísticas también dicen que es los espacios privados, las casas, donde se producen la mayoría de los abusos sexuales.
} 
constituyen, no los datos que aparezcan en un despacho. Esta percepción podría estar relacionada con la creencia instaurada de que las mujeres necesitan de protección, y que como apunta Teresa del Valle, constituyen esos miedos atávicos que se transmiten generacionalmente. Este tipo de uso diferencial en el espacio público se exhibe en las numerosas muestras de precauciones y límites que se llevan a cabo entre las mujeres, como expresa Tamar Pitch, desde la infancia se nos ha enseñado que las calles, la noche y los extraños son peligrosos para nosotras y también que nuestros cuerpos son más vulnerables, así crecemos con ideas y mandatos de que necesitamos protección, a "otros hombres" para que nos protejan de aquellos otros extraños que tememos, lo que es observable en las múltiples peticiones de chicas jóvenes a sus amigos acerca de que las acompañen a casa. En todas las entrevistas, las mujeres, en algún momento, hacen referencia a la soledad, al ir solas, en la noche, como ese momento en el que se despiertan los temores, ellos, sin embargo, no creo lo mencionasen en alguna ocasión, se visualizan a si mismos en la urbe, de noche, solos y sin miedo, o aunque alguno pueda expresar un mínimo temor no es algo que le ocupe tiempo ni le haga limitar sus movimientos. Los hombres se erigen al mismo tiempo en protectores $y$ predadores: "un verdadero callejón sin salida" (Pitch, 2008:285)

Tal vez operan vestigios inconscientes en cuanto a creer que la calle no era reconocida como un espacio de mujeres y que todavía hoy constituye un espacio negado. Considero que el caminar con miedo de alguna forma produce esa idea de que las mujeres no están autorizadas en esos momentos y esos lugares. Como decía Koskela, "al limitar su movilidad a causa del temor, las mujeres reproducen involuntariamente la dominación masculina sobre el espacio”.

Presumo que debe haber ciertas creencias, incorporadas en nuestros poros a una edad muy temprana, de las que no somos conscientes, por tratarse casi de otra piel y nos hacen sentirnos más incomodas cuando recorremos determinados lugares a horas señaladas, pero también debe de haber ciertas realidades invisibilizadas: cada día las mujeres tienen que enfrentarse a 
distintas situaciones como invasiones a su espacio, gestos inapropiados, que incluyen miradas que no necesitan palabras para ser manifiestas, y comentarios acosadores, a modo de piropos, entre otros. En definitiva, sabemos que nuestros cuerpos son violables. Las mujeres tienen un miedo a la agresión sexual que los hombres desconocen, aunque no todas manifiestan este mal como el peor, la idea si existe, incluso en el momento de negarlo, de admitir que no es algo en lo que se piensa. Ellos no enuncian nada al respecto, aunque hay quien sí ha hecho mención acerca de este temor específico a la violación que vive en nosotras, la percepción de Chemi es que la violación sexual no es muy probable en el barrio, así "mujeres y hombres tienen lo mismo que perder", aunque lo que recuerda es que su madre le repetía a su hermana que "las mujeres tienen mucho más que perder". Por un lado rescatar este miedo que a todas nos inculcan a una figura masculina posible potencial de abusar sexualmente de nosotras, de donde ya se extraen otras lecturas: ellos como agresores potenciales, con una sexualidad incontrolable y nosotras como víctimas, sujetas a sus deseos imparables y que en lugar de responder a ellos mediante la defensa de una igual, se nos enseña a evitar, a limitar, a no estar, a obedecer sus mandatos. Por otro lado, quizás, un hombre jamás podrá saber lo que esa mirada, gesto o comentario pueda suponerle a una mujer, las agresiones están tan naturalizadas e invisibilizadas como cotidianas son.

Cierto es que mujeres y hombres tienen formas distintas de acceder al espacio publico urbano. Todas las informantes han mostrado su cartografía del miedo en el barrio, aunque muchas no han sido conscientes de sus lugares negados hasta que no hemos hecho el ejercicio de reflexión; todas han mostrado menor o mayor grado de limitación, temporal y/o espacial, no reconocido a priori, que en algunos casos altera recorridos, veta lugares y moldea ritmos, reduciendo sus derechos a usar el espacio público con la misma libertad que los hombres. La ciudad no es un espacio neutro. Aquí se produce control, jerarquías, exclusión y violencia. El patriarcado aún se esconde en los recovecos de las calles laberínticas. 
Parece que la edad desempodera los cuerpos según se infiere de los comentarios de Paco, pero también de Pepa, una mujer de 70 años con la que conversé sin grabadora (ya que fue algo espontáneo y creí que sacar la grabadora era una tanto invasivo), admitía que ya se sentía más limitada para regresar tarde pero que por el día salía. Lola también hace mención al respecto, conocedora de las dinámicas del barrio, comenta que muchas mujeres, con la edad, no salen porque se sienten más débiles dadas las características específicas del barrio y de sus cuerpos.

Parece que la socialización es fundamental en cuanto a cómo nos posicionamos en el espacio y ante el miedo, siendo éste un elemento que construye género. Son múltiples las advertencias que las mujeres recibimos desde una edad muy temprana, mientras que los mensajes recibidos por ellos son de reforzamiento a sus conductas de riesgo, se les incentiva a hacer, a intentar, a desafiar, a la vez que a nosotras se nos procura una conducta más desde la evitación, se justifica nuestro no hacer, se nos docilita para que no seamos aventuradas sino precavidas, haciendo ejercicio así, de umbrales de riesgo muy distintos. A Mohammed, el barrio le parece absolutamente seguro, apuntando la extrañeza como algo positivo y, ante la posibilidad de perderse entre sus calles entretejidas con la sensación de que es la primera vez que camina por ellas, verbaliza "a mi lo desconocido me dan ganas de conocerlo más", mientras que muchas de nosotras ni siquiera nos planteamos ese espacio incógnito, incluso uno que resulte conocido puede llegar a constituir una muralla imaginaria infranqueable, tal vez por una vivencia ocurrida allí, por algo que nos contaron, parece ser que transmitimos más acerca de lo que nos da miedo que de lo que engendra excitación, ese gozo por el bienestar sentido en un lugar solitario. A nosotras no nos preparan para asumir ese riesgo del que habla Mohammed, ese temor ante lo nuevo que a ellos les acarrea sorpresa, incentivos, en nuestro caso va asociado de no incitación, de prevención y hasta de castigo. A la vez, encuentro limitativo el hecho de no desear estar ahí, en lo desconocido, que no se nos fomente el deseo por lo nuevo, 
por explorar, por ensanchar nuestros mapas, con todo ese cúmulo de emociones que despliega tal acción. Sería más liberador insistir y priorizar las experiencias positivas en el espacio urbano, en lugar de quedarnos en lo que nos sujeta a los mapas fijos, los miedos.

Considero que de todo hay en el barrio, tanto miedo como curiosidad, esto es, sensaciones de viveza, a pesar de que muchas de las personas informantes han expresado temor, explícito o implícito (a través de sus rutas coartadas, sus estrechos mapas o sus límites, estrictos en unos casos y más difuminados en otros), siendo éste contestado, excepto en el caso de Chari, que me ha comunicado una limitación absoluta respecto a estar en determinadas partes del barrio sola, y en el de Marta, ante la que no cabe la posibilidad de estar, en la noche, en esos entramados del corazón albayzinero y sola, aunque manifieste no sentir temor. Aunque sus trazados cartográficos sean más limitados, cada una de las informantes tiene sus estrategias varias, sus técnicas y recursos para no dejar de vivir sus rutinas, sus aventuras y sus salidas nocturnas, con toda la complacencia que permanecer en el espacio público reporta.

Ninguna de ellas ha dejado de hacer cosas que tenían pensadas, sus planes, ideas, momentos lúdicos no han sido restringidos en base a estos miedos, a los que como llevan tanto tiempo cargando en sus espaldas inconscientemente, en algunos casos, encarnados en sus cuerpos, saben como vivir con ellos. Tienen un montón de estrategias que tampoco son dilucidadas si no es porque pensamos en ellas.

En cambio ellos no tienen estrategias, parecen no necesitarlas, a pesar de que los hombres son quienes mayormente son agredidos en el espacio público, atendiendo a esas estadísticas que tampoco a ellos les afecta. Excepto Papa que también su cuerpo acomete prácticas relacionadas con la espacialización y el miedo, me confiesa no pasar por un lugar concreto pero ignora o no le teme a la ruta que la mayoría de las mujeres, ya que ellos no atienden a este mapa, han establecido como parte de ese itinerario del miedo, la zona de San Gregorio. 
Su táctica es usar el teléfono para simular que habla con alguien, suele hacerlo en woolof, su lengua originaria, es un secreto consigo mismo, su caparazón, que le protege hasta que llega a donde va. En comparación a ese gran miedo que manifestaba tener, una alarma constante, me doy cuenta que no cuenta apenas con estrategias, lo cual me hace constatar que su alarma como ya he intuido antes, es una alarma similar a un motor, algo que le enciende y le da potencia para moverse por la calle, lo alerta, pero no le circunscribe a prácticas estrictas.

Tantos años aprendiendo a movernos en lo público, ese lugar en el que coincidimos personas tan diversas, que nos aporta armas distintas a quienes miedos distintos experimentan, que en mayor o menor medida cada unx tiene alguno, pero también sus respuestas varían desde quienes no los necesitan porque mentalmente ya lo tienen gestionado, hasta quienes han aprendido a vivir con ellos y también con sus distintas modalidades de estrategias.

Y todo esto para terminar con la propuesta de que otra ciudad es posible, la ciudad imaginada, sólo cuando se entiendan las percepciones de quienes la componen, cuando se integre lo social y simbólico, las necesidades concretas de quienes la habitan y transitan. Es necesario planificar teniendo en cuenta esta perspectiva social, en la que las mujeres estén implícitas tanto como actoras que la usan y viven, como creadoras que la construyen, expertas conocedoras de lo que una ciudad que las incluya significa. 


\section{BIBLIOGRAFÍA}

- AUGE, Marc. 1995. Los "No Lugares": Espacios del Anonimato: Una Antropología de la Sobremodernidad. Gedisa.

- AUGÉ, Marc. La Nación. http://www.lanacion.com.ar/714868-marc-auge-hay-que-amar-latecnologia-y-saber-controlarla

- BAUMAN, Zygmunt. 2006. Confianza y Temor en la Ciudad. Vivir con Extranjeros. Arcadia: Barcelona.

- BUCKINGHAM, Shelley. 2010. Análisis del Derecho a la Ciudad desde una Perspectiva de Género, en Sugranyes y Mathivet. 2010. Ciudades para Tod@s: Por el Derecho a la Ciudad, Propuestas y Experiencias. Habitat International Coalition (HIC): Chile.

- BOUZADA, Xan. 2001. Los espacios culturales del consumo. Reis. Pp. 51-70.

- CASTEL, Robert. 2004. La inseguridad social. ¿Qué es estar protegido? Manantial: España.

- DAMIANO, Patricia. 2010. De los lugares a los no lugares. http://bibliotecaignoria.blogspot.com/2010/01/marc-auge-de-los-lugares-los-no-lugares.html

- DE CARLI, Natalia 2009. La Construcción del Espacio Público frente al miedo. Identidad, Seguridad y Control en las Sociedades Contemporáneas. Universidad de Sevilla.

- DE CERTEAU, Michel. 1984. The Practice of Everyday Life. University of California Press: Berkeley.

- DE PABLOS, Juan Carlos y Ligia Sánchez. 2003. Estilos de vida y revitalización del espacio urbano. Departamento de Sociologia, Universidad de Granada: Granada. Pp.11-31.

- DE PABLOS, Juan Carlos y Julio Cabrera. 2002. Metamorfosis del Albaicín (Granada): Del Aislamiento a la Interdependencia. Departamento de Sociología de la Universidad de Granada. Cuadernos Geográficos, 32. Pp. 73-96

- DELGAdO, Manuel. 2007. Sociedades Movedizas. Pasos Hacia una Antropología de las Calles. Anagrama: Barcelona. 
- DEL VAlLE, Teresa. 1997. Andamios Para una Nueva Ciudad. Lecturas desde la Antropología. Cátedra: Madrid.

- _ 1999. Procesos de la Memoria. Cronotopos Genéricos. La Ventana, no 9.

- DÍAZ Parra, Iban. 2007. Geografía del miedo y el consumo en Sevilla. Departamento Geografía Humana. Universidad de Sevilla.

- DOUGLAS, Mary. 2003. Purity and Danger. An Analysis of Concepts of Pollution and Taboo. Routledge: London

- FERnANDEZ, Manu. 2012. Lo Urbano en la Ciudad Inteligente. La Ciudad Viva. http://www.laciudadviva.org/blogs/?p=13589

- FENSTER, Tovi. 2010. El Derecho a la Ciudad y la Vida Cotidiana basada en el Género, en Sugranyes y Mathivet. 2010. Ciudades para Tod@s: Por el Derecho a la Ciudad, Propuestas y Experiencias. Habitat International Coalition (HIC): Chile.

- FOUCAULT, Michel. 2005. Vigilar y Castigar. Nacimiento de la prisión. S. XXI: México.

- ----. 1991. Historia de la Sexualidad I. La Voluntad del Saber. Siglo XXI: México.

- FOUST, David. 2011. Miedo, Ira y Esperanza en México. Emociones, Percepciones y Reacciones en torno del Crimen, el Riesgo y el Cambio Social. Intersticios Sociales, ㄲo 1

- GARCÍA, Alejandra.2006. En Construcción. Geografías del Poder y Sentidos del Lugar en San Salvador de Jujuy. Universidad Nacional de Jujuy, Argentina. Unirevista, vol. 1, no 3.

- GARCÍA, Sergio. Incorporación de la Inseguridad en Contextos Urbanos y Agencialidad, en Josep Martí y Yolanda Aixelá (coord.). 2010. Desvelando el Cuerpo. Perspectiva desde las Ciencias Sociales y Humanas. Consejo Superior de Investigaciones Científicas, Institución Milá y Fontanals: España. pp. 85-107.

- GHANNAM, Farha. 2002. Remaking the modern. Space, relocation, and the Politics of Identity in a Global Cairo. University of California Press: London, England. Pp. 88-116.

- GIRALDO Diez, Reinaldo. 2006. Poder y Resistencia en Michel Foucault. Tábula Rasa, no4 
http://www.scielo.org.co/scielo.php?pid=S1794-24892006000100006\&script=sci_arttext

- GONZÁLEZ Alcantud, Jose Antonio. 2005. La ciudad Vórtice. Lo local, lugar fuerte de la memoria en tiempos de errancia. Anthropos: Granada.

- GUTIERREZ, Obdulia. (Coord.). 2005. La Ciudad y el Miedo. VII Coloquio de Geografía $\begin{array}{llll}\text { Urbana. } & \text { Universidad } & \text { Gerona: }\end{array}$ http://www.uib.es/ggu/pdf_VII\%20COLOQUIO/actes\%20copia.pdf

- HARVEY, David. El derecho a la ciudad. http://www.sinpermiso.info/textos/index.php?id=2092

- $\quad$ HALL, S. 1995. New Cultures for Old, en Massey Doreen and Pat Jess. 1995. A place in the World? Places, Culture and Globalization. Oxford University Press: Oxford.

- HERNÁNDEZ, Jone Miren. 1999. Auto/biografía. Auto/etnografía. Auto/retrato. Universidad del País Vasco.

- KOSKELA, Hille. 1999. "Gendered exclusions: Women's fear of violence and changing relations to space. Geografiska Annaler, series B, Human Geography, vol. 81, num. 2, pp. 111-124.

- LEFEBVRE, Henri. 1978. El Derecho a la Ciudad. Península: Barcelona.

- LÓPEZ, Liliana e Isabel Rodríguez. 2005. Evidencias y Discursos del Miedo en la Ciudad: Casos Mexicanos. Scripta Nova. Revista Electrónica de Geografía y Ciencias Sociales, vol. 9, ำ 194.

- MADGE, C. 1997. Public parks and the geography of fear. Tijdschrift voor Economische en Sociale Geografie, 88, pp. 237-250.

- MACASSI, Ivonne. 2005. El Miedo a la Calle: la Seguridad de las Mujeres en la Ciudad. $\begin{array}{llllll}\text { Centro de } & \text { la } & \text { Mujer } & \text { Peruana } & \text { Flora }\end{array}$ http://www.flora.org.pe/pdfs/PDF\%20EL\%20MIEDO\%20A\%20LA\%20CALLE.pdf 
- MARSH, J. and Nunn, P.G.1989. Women Artists and the Pre-Raphaelite Movement, London.

- MUXI Martinez, Zaida. 2008. El espacio no es neutro: Reflexiones en Torno a Vivienda y Ciudad desde una Perspectiva de Género. http://us.arqa.com/index.php/esc/colaboraciones/el-espacio-no-es-neutro-reflexiones-entorno-a-vivienda-y-ciudad-desdeuna-perspectiva-de-genero.html

- MASSEY, Doreen.1995. "The conceptualization of place" A Place in the World? Place, Culture and Globalization. Oxford University Press: Oxford. pp. 45-85.

- _ _ 1994. Space, Place and Gender. University of Minnesota Press: Minneapolis.

- ___ John Allen y Michael Prike. 1999. Unsettling cities. The Open University.

- MILLAN Scriche, Mercedes. 2004. La Geografía de la Percepción: Una Metodología de Análisis para el Desarrollo Local. Universidad de Murcia: Murcia. Pp. 133-149

- NAREDO, María. 2010. Miedo de las Mujeres como Instrumento del Patriarcado. El Papeles de Relaciones Ecosociales y Cambio Global no 109, pp. 79-86.

- NUÑEZ, Ana. 2009. De la Alienación, al Derecho a la Ciudad. Una Lectura (posible) sobre Henri Lefebvre. Revista Theomai. Estudios sobre sociedad y desarrollo. http://revista-theomai.unq.edu.ar/NUMERO20/3ArtNunez.pdf

- ORTIZ, Anna. 2006. Regeneración Urbana, Espacio Publico y Sentido del lugar. Un caso de estudio en la Ciudad de Mexico. Universidad de los Andes: Venezuela. Red de Revistas Cientificas de America Latina, Caribe, España y Portugal. Provincia, enero-junio, no15, pp. 41-63.

- PAIN, Rachel. 1997. Social geography of women's fear of crime. Transactions of the Institute of British Geographers, 22, pp. 231-244. 
- PITCH, Tamar. 2008. Congreso Internacional Sare: Masculinidad y Vida Cotidiana. Emakunde http://www.emakunde.euskadi.net/u72publicac/es/contenidos/informacion/pub_jornadas/es_ emakunde/adjuntos/sare2007_es.pdf.

- RAMIREZ Casas, Jimena. 2002. EL MIEDO: reflexiones sobre su dimensión social y cultural. Corporación Región: Medellín

- REGUILLO, Rossana. 1998. Imaginarios Globales, Miedos Locales. La Construcción Social Del Miedo En La Ciudad. Universidad de Guadalajara. Departamento de Estudios Socioculturales.

- _ _ 1996. Los Lenguajes del Miedo. ¿Nuevos Escenarios, Nuevos?. León. Revista Renglones, 35. Pp. 69-74.

- _ _ 1996. Los Mitos Gozan de Cabal Salud. El Horizonte de las Creencias Colectivas en la Modernidad Mexicana. Comunicación y Sociedad, № 47, pp. 215-238.

- ROSALDO, Michelle. 1979. Mujer, Cultura y Sociedad: Una Visión Teórica, en Harris, Olivia y Kate Young (compiladoras). Antropología y Feminismo. Editorial Anagrama: Barcelona. Pp. 153-181.

- ROSE, Gillian. 1995. Place and Identity: A Sense of Place, en Massey, Doreen and Pat Jess. 1995. A Place in the World? Places, Culture and Globalization. Oxford University Press: Oxford.

- SABATÉ, Ana, Juana Rodriguez y Mํa Ángeles Díaz. 1995. Mujeres, Espacio y Sociedad. Hacia una Geografía del Género. Síntesis: Madrid.

- SANCHEZ, Marcela y Sergio Merino. 2007. El problema del miedo en la ciudad: una temática para la investigación y enseñanza en la Geografía Contemporánea. Revista Universitaria de Geografía. V.16, n.1. Bahía Blanca. 
- SEguRA, Ramiro. Territorios Del Miedo En El Espacio Urbano De La Ciudad de La Plata: Efectos Y Ambivalencias. Universidad Nacional de la Plata. Argentina.

- SOTO, Paula. 2011. La Ciudad Pensada, la Ciudad Vivida, la Ciudad Imaginada. Reflexiones teóricas y empíricas. Universidad de Guadalajara: Guadalajara. Revista de $\begin{array}{llllll}\text { Estudios de Género La } & \text { 7-38. }\end{array}$ http://www.redalyc.org/src/inicio/ArtPdfRed.jsp?iCve=88422488004

- SUGRANYES, Ana y Charlotte Mathivet. 2010. Ciudades para tod@s: Articulando Capacidades Sociales Urbanas, en Ciudades para Tod@s: Por el Derecho a la Ciudad, Propuestas y Experiencias. Habitat International Coalition (HIC): Chile. http://www.google.es/url?sa=t\&rct=i\&q=\&esrc=s\&source=web\&cd=2\&ved=0CCcQFjAB\&url= http\%3A\%2F\%2Fwww.hic-net.org\%2Fcontent\%2FCiudades\%2520para\%2520todosESP.pdf\&ei=tH1kUMHIMc6QhQfSxoCIAQ\&usg=AFQjCNHqauXR5 KHXrOHX2z9qK id6veg\&sig2=K7Hq8uOA JShL4ClwgB4Ng

- TERREN, Eduardo. 2011. Identidades desterritorializadas. El sentimiento de pertenencia nacional entre los adolescents de familias inmigradas. Universidad de Salamanca. Departamento de Sociologia y Comunicación. Pp. 97-116. http://ddd.uab.cat/pub/papers/02102862v96n1/02102862v96n1p97.pdf

- VARA Muñoz, José Luis. 2010. Un análisis necesario: Epistemología de la Geografía de la Percepción. Consejería de Educación e Investigación: Madrid. Papeles de Geografía, 51-52, pp.337-344.

- VICTORIA, Carlos A. 2002. El miedo que nos habita: elementos para la interpretación de una sociología de la seguridad. Instituto de cultura de Pereira-Observatorio de Cultura: Pereira, Colombia. http://aprendeenlinea.udea.edu.co/revistas/index.php/ceo/article/viewFile/6880/6297 
- WIGEN, Kareen and Lewis, Martin. 1997. "The myth of Continents. A critique of Metageography. University of California Press: California.

- WILSON, Elizabeth. 2001. 'The invisible Flaneur' in The contradictions of culture. Sage: London.

- file://C:/Users/AC/Documents/mujeres\%20de\%20toronto\%20CIUDAD\%20SEGURA.htm

- http://granadaimedia.com/la-casa-del-miedo-del-albaicin/\#comment-3935

- http://www.albayzin.info/Principal.htm 
6. ANEXOS 


\section{ENTREVISTA A PERSONAS QUE HABITAN Y TRANSITAN EL ALBAIZIN}

1 ¿Podrías describir qué entiendes por miedo?

2 ¿Cuándo sientes miedo? (horas, estación del año, en soledad, espacios abiertos, cerrados, oscuros,.....)

3 ¿A quién le tienes miedo?

4 ¿Qué es lo que más temes?

5 ¿Consideras que es seguro el barrio?

6 ¿Qué lugares te hacen sentir más insegura? ¿Podrías localizar en el mapa estos lugares?

$7 \quad$ ¿Y qué lugares te hacen sentir más segura?

8 ¿Piensas que esto ha sido siempre así o ha cambiado con el tiempo?

9 ¿Crees que hay una correspondencia entre entre el miedo que puedes sentir y la realidad objetiva de lo que ocurre?

10 ¿Has sufrido alguna mala experiencia?

11 ¿Y alguien de tus amistades o familiares?

12 ¿Qué has escuchado acerca de las historias del barrio a este respecto?

13 ¿Por parte de quién?

14 ¿Cuáles son las advertencias que tu familia te da cuando sales sol@?

15 ¿Qué haces cuando tienes miedo? ¿Qué estrategias utilizas? (enfrentarse al miedo, cambiar la ruta, ir en taxi, regresar temprano con transporte público,...)

16 ¿Hay veces que cambias de idea respecto a lo que querías hacer previendo esta situación, para evitar sentir miedo?

17 ¿Crees que hay diferencia en el miedo que tú sientes y el de tus amigas?

18 ¿Y con tus amigos? ¿Crees que ellos viven igual el miedo? ¿Por qué?

19 ¿Crees que te sentirías más segur@ si hubiese cámaras y policía alrededor?

20 ¿Que propuestas o alternativas sugieres para reducir esta sensación de riesgo?

21 ¿Cuál sería para ti la solución?

22 ¿Crees que hay alguna fórmula para no sentir miedo? 


\section{ENTREVISTA ASOCIACIÓN VECINAS Y VECINOS DEL ALBAIZÍN}

1 ¿Cómo definirías el miedo?

2 ¿A qué se tiene miedo?

3 ¿Quiénes crees que sienten más miedo? ¿Por qué?

4 ¿Crees que los miedos van cambiando? ¿en función de qué? (antes temíamos a figuras que ya no nos asustan más)

5 ¿Podrías contarme alguna historia o leyenda tradicional relacionada con el miedo en ciertas partes del barrio que las personas mayores solían transmitir a las generaciones más jóvenes?

6 ¿Consideras que el Albaizín es un barrio inseguro? ¿Qué factores pueden influir en ello?

7 ¿Qué reacción provoca en el barrio? ¿Qué hace la gente con sus miedos?

8 ¿Hay algun tipo de organización al respecto?

9 La situación del barrio ¿ha sido así desde siempre o ha cambiado? ¿cuándo y porqué?

10 ¿Cómo describirías un lugar que da miedo? ¿que hay y que no hay?

11 ¿Dónde se ubica este miedo, en qué lugares?

12 ¿Podrías señalar en el mapa los lugares más inseguros?

13 ¿Hay cámaras en el barrio, policía u otras medidas?

14 ¿Como se podría mejorar? ¿tienes alguna sugerencia? 
